\title{
WestVirginiaUniversity
}

THE RESEARCH REPOSITORY @ WVU

Graduate Theses, Dissertations, and Problem Reports

2003

\section{Effluent characterization of flow-through aquaculture operations in West Virginia}

James $\mathrm{H}$. Cunningham

West Virginia University

Follow this and additional works at: https://researchrepository.wvu.edu/etd

\section{Recommended Citation}

Cunningham, James H., "Effluent characterization of flow-through aquaculture operations in West Virginia" (2003). Graduate Theses, Dissertations, and Problem Reports. 1344.

https://researchrepository.wvu.edu/etd/1344

This Thesis is protected by copyright and/or related rights. It has been brought to you by the The Research Repository @ WVU with permission from the rights-holder(s). You are free to use this Thesis in any way that is permitted by the copyright and related rights legislation that applies to your use. For other uses you must obtain permission from the rights-holder(s) directly, unless additional rights are indicated by a Creative Commons license in the record and/ or on the work itself. This Thesis has been accepted for inclusion in WVU Graduate Theses, Dissertations, and Problem Reports collection by an authorized administrator of The Research Repository @ WVU. For more information, please contact researchrepository@mail.wvu.edu. 
Effluent Characterization of Flow-Through

Aquaculture Operations in West Virginia

\author{
James H. Cunningham
}

Thesis submitted to the

College of Engineering and Mineral Resources

at West Virginia University

in partial fulfillment of the requirements

for the degree of

Master of Science

in

Civil and Environmental Engineering

\author{
Roger C. Viadero, Jr., Ph.D., Chair \\ Ronald H. Fortney, Ph.D. \\ Kenneth J. Semmens, Ph.D. \\ Department of Civil and Environmental Engineering
}

\author{
Morgantown, West Virginia
}

2003

Keywords: Aquaculture Effluent, Water Quality, Rainbow Trout, Production Potential

Copyright 2003 James H. Cunningham 


\section{ABSTRACT \\ Effluent Characterization of Flow-Through \\ Aquaculture Operations in West Virginia}

\section{James H. Cunningham}

In order to reduce pollutant loading nationwide, the USEPA working in conjunction with the USDA, is in the process of developing effluent management guidelines and standards for private and public aquaculture operations. The purpose of this study is to provide industry, State, and Federal stakeholders with baseline effluent water quality data specific to West Virginia flow-through facilities, in an effort to help concerned parties make informed decisions regarding impending regulations and to examine the potential to increase production, based on effluent pollutant load and permit limitations.

WVU-CEE researchers examined both large and small-scale facilities in this project with varying water sources, rearing capacities, and effluent treatment methods. All facilities reared Oncorhynchus mykiss (rainbow trout). The influent and effluent of the six anonymous facilities were monitored approximately every six weeks for flow, temperature, conductivity, dissolved oxygen, turbidity, biochemical oxygen demand, total suspended solids, total ammonia nitrogen, nitrite, nitrate, and total phosphorus. Using flow rate and pollutant concentrations, mass loadings were then calculated for each constituent.

Average concentrations and mass loadings of regulated parameters were within acceptable ranges as well as anticipated regulatory limits. Potential for increased production exist at each facility based on effluent pollutant load and permit limitation. 


\section{TABLE OF CONTENTS}

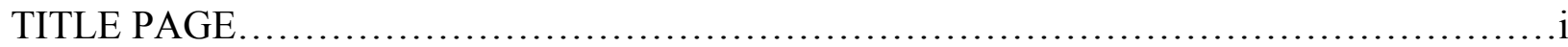

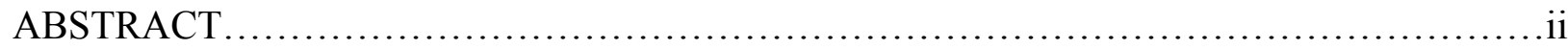

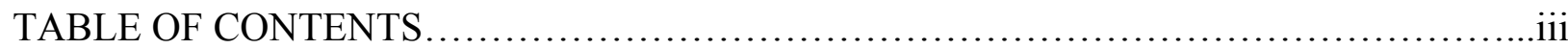

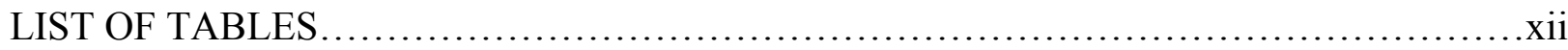

LIST OF FIGURES....................................................................

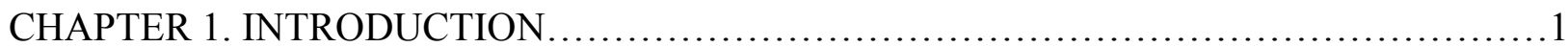

1.1 Problem Statement........................................................

1.2 Objectives................................................................

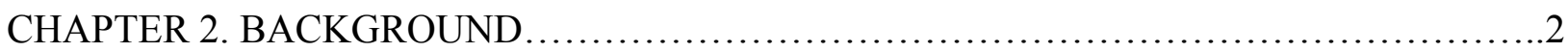

2.1 Overview of Aquaculture in West Virginia.....................................

2.2 Culture Systems......................................................

2.2.1 Linear Units....................................................

2.2.2 Circular Units..........................................................

2.3 Water Resources.........................................................4

2.3.1 Groundwater..........................................................

2.3.2 Surface Water.....................................................

2.4 Water Quality Criteria for Rainbow Trout.......................................5

2.4.1 Ammonia Nitrogen................................................5

2.4.2 Carbon Dioxide................................................6

2.4.3 Nitrate..........................................................6

2.4.4 Nitrite.......................................................6

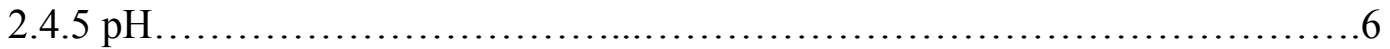




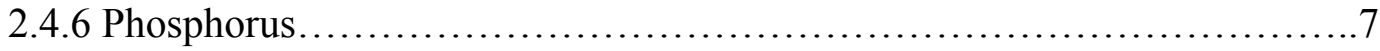

2.4.7 Total Suspended Solids..............................................

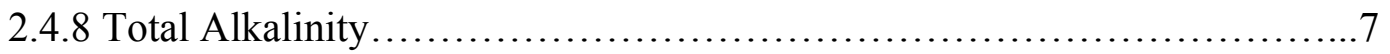

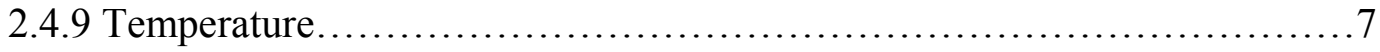

2.5 Aquaculture Effluent Pollutants.................................................

2.5.1 Organic Pollutants.................................................... 8

2.5.2 Nutrient Pollutants................................................... 8

2.5.2.1 Nitrogen................................................... 9

2.5.2.2 Phosphorus...................................................

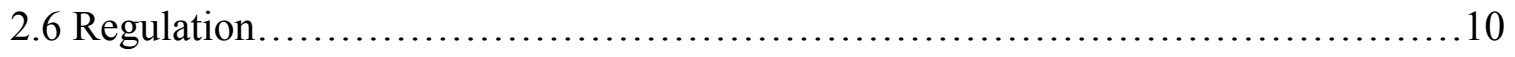

2.6.1 Federal Regulation.................................................. 10

2.6.2 State Regulation................................................ 10

2.7 Effluent Management......................................................... 10

2.7.1 Dissolved Pollutant Management.....................................10

2.7.2 Suspended Pollutant Management....................................11

CHAPTER 3. INVESTIGATIVE APPROACH........................................ 11

3.1 Experimental Design...................................................... 11

3.1.1 Site Selection..................................................... 11

3.1.1.1 Water Source..............................................12

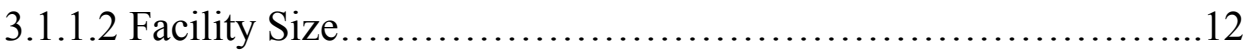

3.1.1.3 Effluent Treatment........................................13

3.1.1.4 Operator Feeding Practices....................................13

3.1.2 Description of Research Sites.........................................13 
3.1.2.1 Facility A.................................................13

3.1.2.2 Facility B................................................. 16

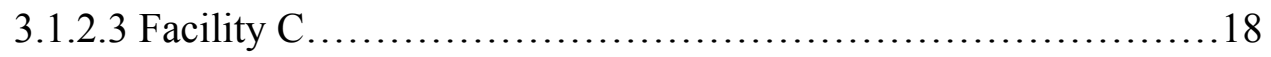

3.1.2.4 Facility D...................................................

3.1.2.5 Facility E.................................................. 21

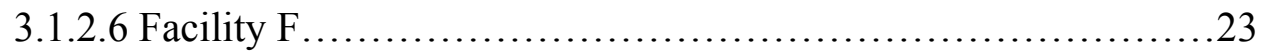

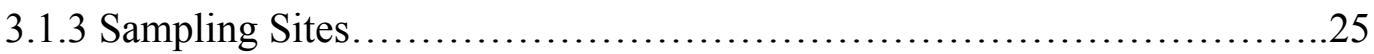

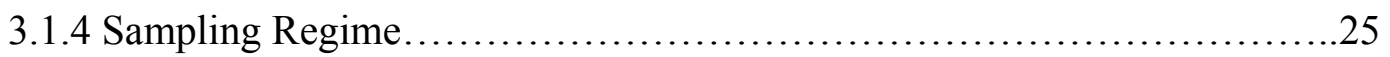

3.1.5 Field Monitoring and Grab Samples..................................26

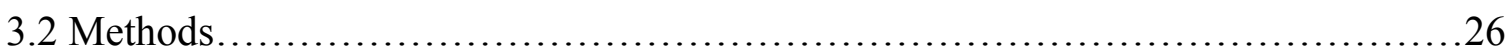

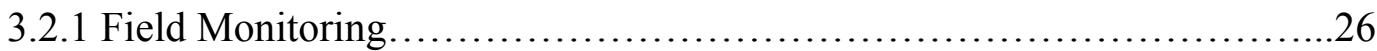

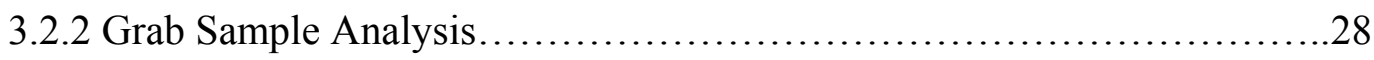

3.2.2.1 Nutrients..................................................... 28

3.2.2.2 Biochemical Oxygen Demand.................................28

3.2.2.3 Solids ....................................................... 28

3.3 Quality Assurance and Quality Control.......................................29

3.3.1 External Laboratory Analyses............................................29

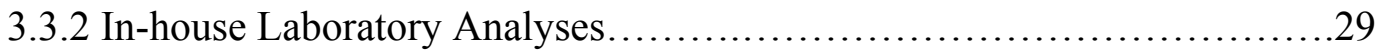

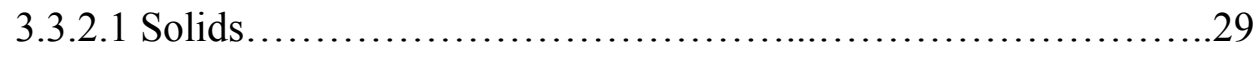

3.3.2.2 Biochemical Oxygen Demand...................................29

3.3.2.3 Field Meters................................................. 30

3.4 Statistical Analyses...............................................................

3.4.1 Paired t-Test......................................................... 
3.4.1 Wilcoxon Signed Rank Test.........................................32

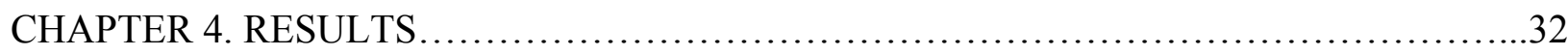

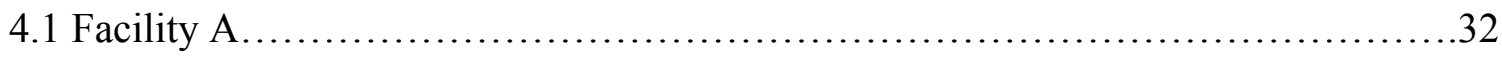

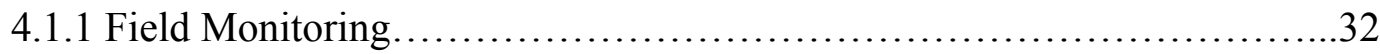

4.1.1.1 Flow............................................................ 33

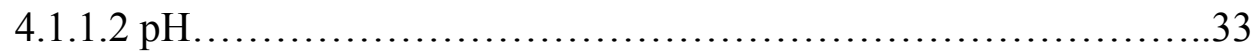

4.1.1.3 Specific Conductance.......................................33

4.1.1.4 Temperature................................................. 33

4.1.1.5 Dissolved Oxygen.............................................

4.1.1.6 Turbidity.................................................. 34

4.1.2 Grab Samples..................................................... 34

4.1.2.1 Total Suspended Solids (TSS) ................................35

4.1.2.2 Five Day Biochemical Oxygen Demand $\left(\mathrm{BOD}_{5}\right) \ldots \ldots \ldots \ldots \ldots \ldots . \ldots . \ldots . \ldots 35$

4.1.2.3 Total Ammonia Nitrogen (TAN) .............................36

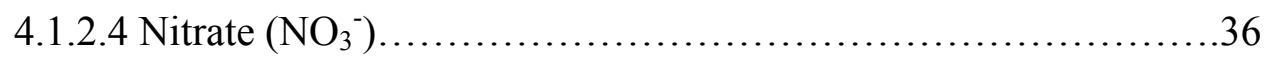

4.1.2.5 Total Phosphorus (TP) .........................................36

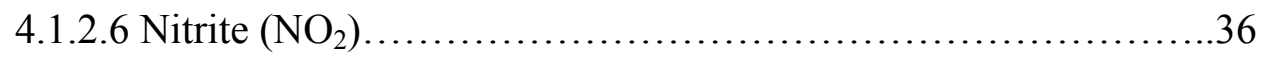

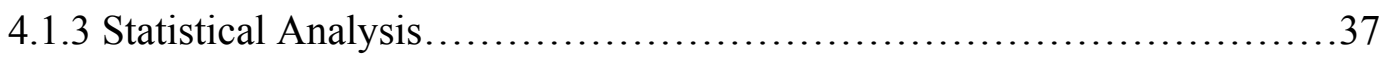

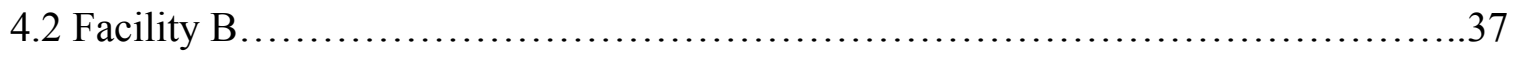

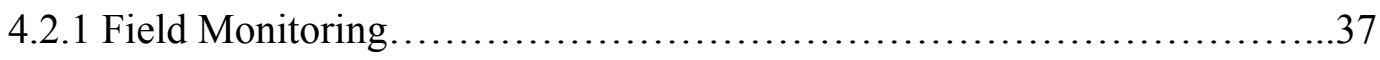

4.2.1.1 Flow ........................................................

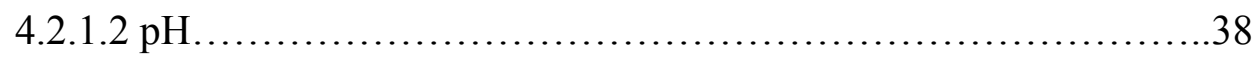

4.2.1.3 Specific Conductance ......................................38 
4.2.1.4 Temperature ..................................................

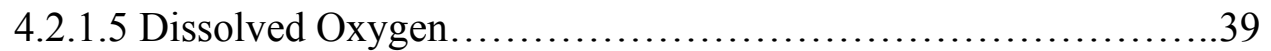

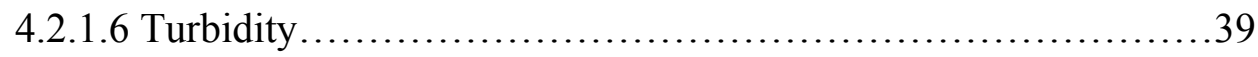

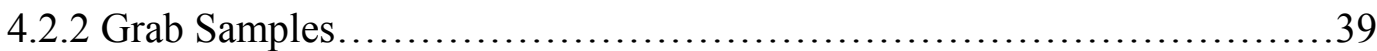

4.2.2.1 Total Suspended Solids (TSS) $\ldots \ldots \ldots \ldots \ldots \ldots \ldots \ldots \ldots \ldots \ldots . . . \ldots 40$

4.2.2.2 Five Day Biochemical Oxygen Demand $\left(\mathrm{BOD}_{5}\right) \ldots \ldots \ldots \ldots \ldots \ldots . . . .40$

4.1.2.3 Total Ammonia Nitrogen (TAN) ..............................40

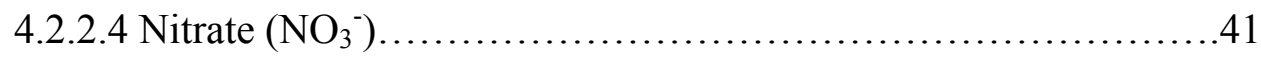

4.2.2.5 Total Phosphorus (TP) .....................................41

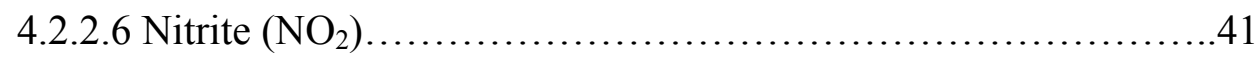

4.2.3 Statistical Analysis...................................................4

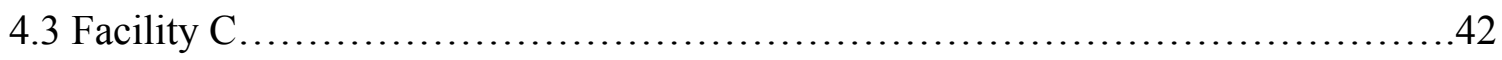

4.3 .1 Field Monitoring ................................................... 42

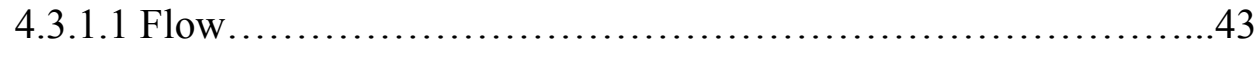

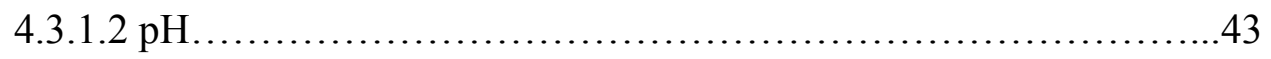

4.3.1.3 Specific Conductance ......................................43

4.3.1.4 Temperature................................................43

4.3.1.5 Dissolved Oxygen...........................................43

4.3 .1 .6 Turbidity .................................................... 44

4.3.2 Grab Samples........................................................ 44

4.3.2.1 Total Suspended Solids (TSS) ..............................44

4.3.2.2 Five Day Biochemical Oxygen Demand $\left(\mathrm{BOD}_{5}\right) \ldots \ldots \ldots \ldots \ldots \ldots . . . .45$

4.3.2.3 Total Ammonia Nitrogen (TAN) .............................45 


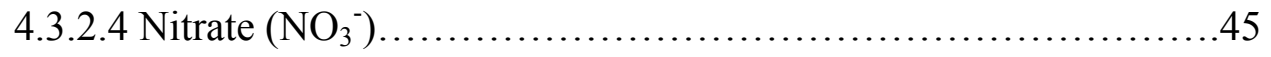

4.3.2.5 Total Phosphorus (TP)......................................45

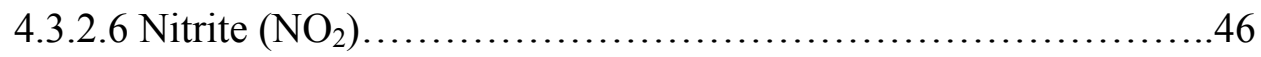

4.3.3 Statistical Analysis...............................................46

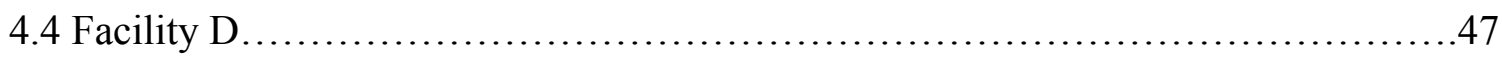

4.4.1 Field Monitoring ................................................... 47

4.4.1.1 Flow......................................................... 47

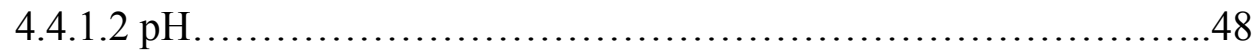

4.4.1.3 Specific Conductance......................................48

4.4.1.4 Temperature............................................... 48

4.4.1.5 Dissolved Oxygen..........................................48

4.4 .1 .6 Turbidity ................................................. 49

4.4.2 Grab Samples......................................................49

4.4.2.1 Total Suspended Solids (TSS) .................................49

4.4.2.2 Five Day Biochemical Oxygen Demand $\left(\mathrm{BOD}_{5}\right) \ldots \ldots \ldots \ldots \ldots \ldots . . . .50$

4.4.2.3 Total Ammonia Nitrogen (TAN) .............................50

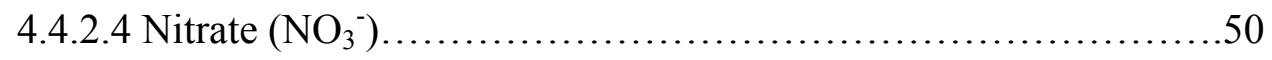

4.4.2.5 Total Phosphorus (TP) .....................................50

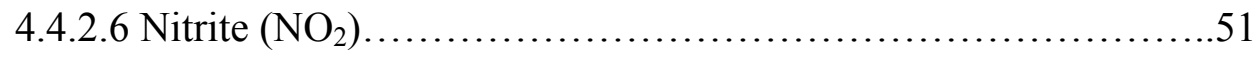

4.4.3 Statistical Analysis....................................................51

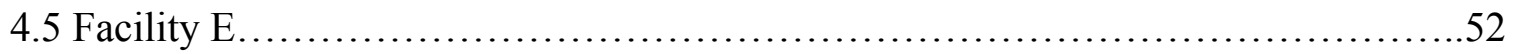

4.5.1 Field Monitoring ..................................................52

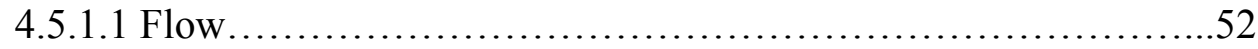


4.5.1.3 Specific Conductance.........................................53

4.5.1.4 Temperature...............................................53

4.5.1.5 Dissolved Oxygen..........................................53

4.5.1.6 Turbidity................................................... 53

4.5.2 Grab Samples..................................................5

4.5.2.1 Total Suspended Solids (TSS) ..............................54

4.5.2.2 Five Day Biochemical Oxygen Demand $\left(\mathrm{BOD}_{5}\right) \ldots \ldots \ldots \ldots \ldots \ldots . \ldots 5$

4.5.2.3 Total Ammonia Nitrogen (TAN) ..............................55

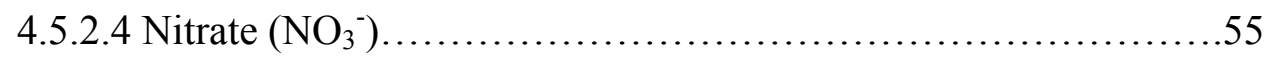

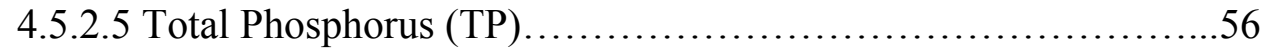

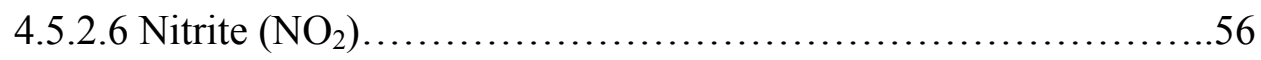

4.5.3 Statistical Analysis..................................................56

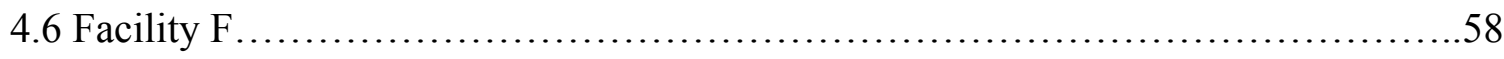

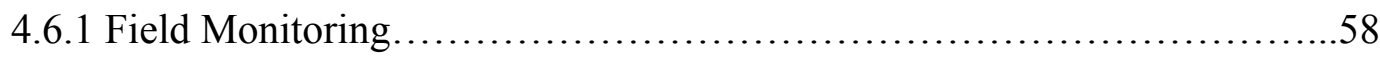

4.6.1.1 Flow.........................................................

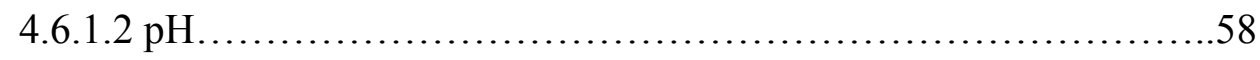

4.6.1.3 Specific Conductance ......................................58

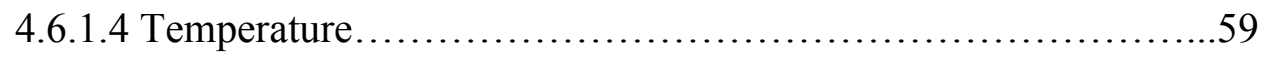

4.6.1.5 Dissolved Oxygen.............................................59

4.6.1.6 Turbidity ................................................... 59

4.6.2 Grab Samples...................................................59

4.6.2.1 Total Suspended Solids (TSS) ..............................60 
4.6.2.2 Five Day Biochemical Oxygen Demand $\left(\mathrm{BOD}_{5}\right) \ldots \ldots \ldots \ldots \ldots 60$

4.6.2.3 Total Ammonia Nitrogen (TAN) ...........................60

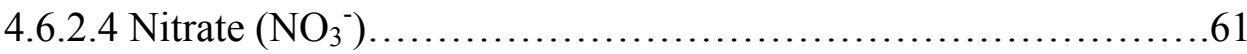

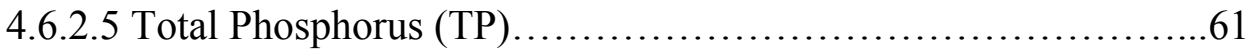

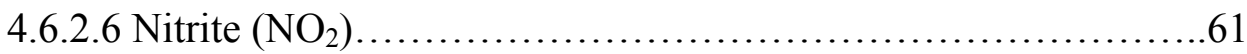

4.6.3 Statistical Analysis.............................................61

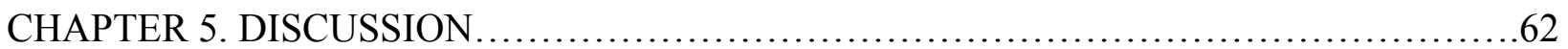

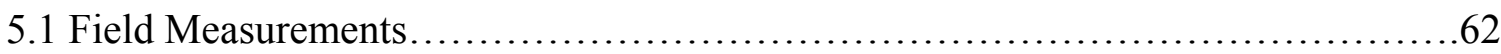

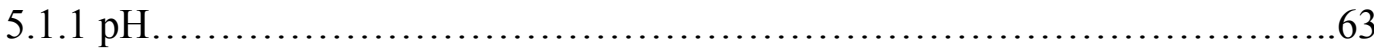

5.1.2 Dissolved Oxygen............................................64

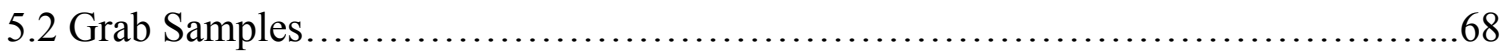

5.2.1 Un-ionized Ammonia Nitrogen...................................70

5.3 Pollutant Spikes....................................................... 72

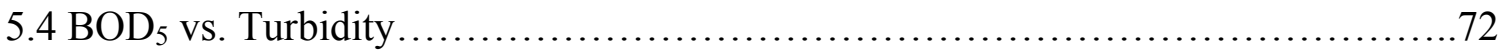

5.5 Increased Production Potential........................................... 74

CHAPTER 6. SUMMARY AND CONCLUSIONS ......................................78

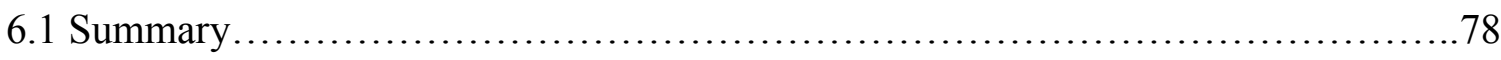

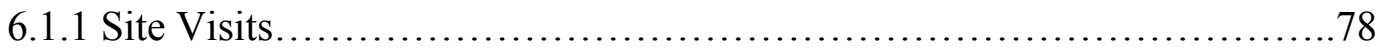

6.1.2 Data Analysis................................................78

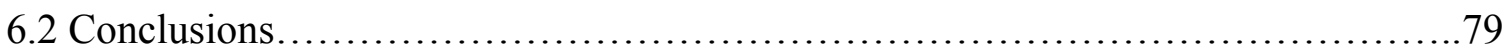

6.2.1 Effluent Characteristic.......................................... 79

6.2.2 Production Potential................................................ 80

6.2.3 Further Research................................................80 


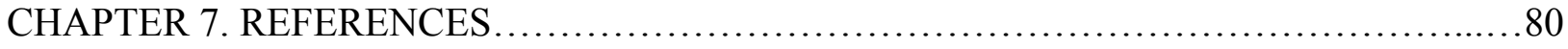

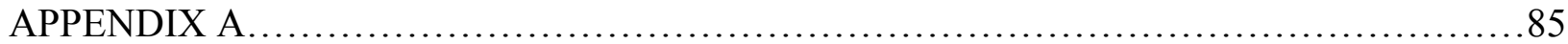

APPENDIX B................................................................. 88

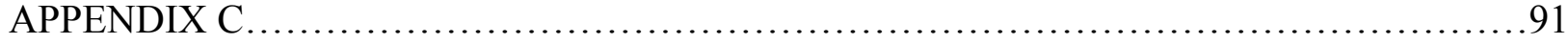

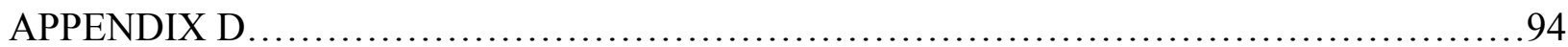

APPENDIX E.................................................................. 97

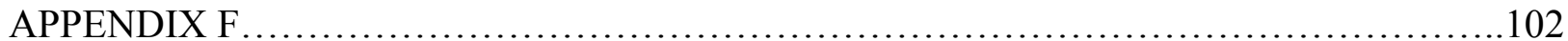




\section{LIST OF TABLES}

TABLE

PAGE

Table 2.4.1

Water Quality Criteria for Salmonid Production (IDEQ, 1998)

5

Table 3.1

Site characteristics of the six facilities.

Table 3.1.1.1.1 NPDES Permit Requirements for Facility A.

Table 3.1.2.2.1 NPDES Permit Requirements for Facility B.

Table 3.2.1.1 Instruments Employed in Field Monitoring.

Table 3.2.2.2 Location and Methods of Flow Determination at Study Sites. 28

Table 3.2.2.1 Analytical Methods Used in Assays Performed by the NRCCE.

Table 4.1.1.1 Field Monitoring Results of Facility A.

Table 4.1.2.1

Grab Sample Results of Facility A.

Table 4.1.3.1 Facility A Water Quality Monitoring Statistical Analysis Results.

Table 4.2.1.1 Field Monitoring Results of Facility B

Table 4.2.2.1 Grab Sample Results of Facility B

Table 4.2.3.1 Facility B Water Quality Monitoring Statistical Analysis Results.

Table 4.3.1.1 Field Monitoring Results of Facility C.

Table 4.3.2.1 Grab Sample Results of Facility C.

Table 4.3.3.1 Facility C Water Quality Monitoring Statistical Analysis Results.

Table 4.4.1.1 Field Monitoring Results of Facility D.

Table 4.4.2.1 Grab Sample Results of Facility D.

Table 4.4.3.1 Facility D Water Quality Monitoring Statistical Analysis Results.

Table 4.5.1.1 Field Monitoring Results of Facility E.

Table 4.5.2.1 Grab Sample Results of Facility E.

Table 4.5.3.1

Facility E Effluent Water Quality Monitoring Statistical Analysis

Table 4.5.3.2 Results.

Table 4.6.1.1 Field Monitoring Results of Facility F.

Table 4.6.2.1 Grab Sample Results of Facility F.

Table 4.6.3.1 Facility F Water Quality Monitoring Statistical Analysis Results. 
Table 5.1 Average Change in Measured Parameters from Influent to Effluent. 62

Table 5.1 Normal Ranges of Pollutant Concentration Increase Reported by $\quad 67$

Table 5.2.2 Average Changes in Pollutant Concentrations and Mass Loading from 69

$\begin{array}{lll} & \text { Influent to Effluent for All Participating Facilities. } \\ \text { Table 5.2.1.1 } & \text { Calculated Un-ionized Ammonia Concentrations, Mass Loads, and } & 71\end{array}$

Table 5.5.1 Production Impacts of Various TSS Effluent Limitations. 75

Table 5.5.2 Production Impacts of Two TAN Effluent Limitations. 76

Table 5.5.3 Production Impacts of $\mathrm{BOD}_{5}$ Effluent Limitation. 76

Table 5.5.4 Production Impacts at two TP Effluent Limitations. $\quad 77$ 


\section{LIST OF FIGURES}

Figure

Figure 2.2.1.1. Schematic of typical linear fish culture unit.

Page

Figure 2.2.2.1. Schematic of typical circular fish culture unit. $\quad 4$

$\begin{array}{lll}\text { Figure 2.5.2.1 } & \text { Fate of feed nitrogen }(\mathrm{N}) \text { and phosphorus }(\mathrm{P}) . & 9\end{array}$

Figure 3.1.1 Process Flow Diagram of Facility A. $\quad 14$

Figure 3.1.2 Photograph of Granular Media Filters of Facility A. 15

Figure 3.1.3 Photograph of Aspirator System for Aeration at Facility A. 15

Figure 3.1.4 Process Flow Diagram of Facility B. 16

Figure 3.1.5 A Photograph of the Sedimentation Basin and Granular Media Filters 17

$\begin{array}{lll}\text { Figure 3.1.6 Process Flow Diagram of Facility C. } & 18\end{array}$

$\begin{array}{lll}\text { Figure 3.1.7 } & \text { Photograph of Raceway System at Facility C. }\end{array}$

Figure 3.1.8 Process Flow Diagram of Facility D. 20

Figure 3.1.9 Photograph of Surface Aerators at Facility D. 21

Figure 3.1.10 Process Flow Diagram of Facility E. 21

Figure 3.1.11 Packed Aeration Column 22

Figure 3.1.12 Liquid Oxygen Tanks of Facility E. 23

Figure 3.1.13 Process Flow Diagram of Facility F. 24

Figure 3.1.14 Photograph of the Circular Tanks at Facility F. 25

Figure 5.1.1.1 Average Effluent $\mathrm{pH}$ of Each Facility and Permit Limitations.

Figure 5.1.2.1. Influent and Effluent DO Concentrations of Facility A. 63

Figure 5.1.2.2. Influent and Effluent DO Concentrations of Facility D. 63

Figure 5.1.2.3. Influent and Effluent DO Concentrations of Facility F. 64

Figure 5.1.2.4. Influent and Effluent DO Concentrations of Facility B. 65 
Figure 5.1.2.5. Influent and Effluent DO Concentrations of Facility C. 65

Figure 5.1.2.6. Influent and Effluent DO Concentrations of Facility E. 65

Figure 5.2.1.1 Ammonia Speciation as a Function of $\mathrm{pH} . \quad 71$

Figure 5.4.1. Turbidity vs. BOD 5 for Facility A. $\quad 72$

Figure 5.4.2. Turbidity vs. BOD $_{5}$ for Facility E. $\quad 73$

Figure 5.4.3. Turbidity vs. BOD $_{5}$ for Facilities A and E. $\quad 73$ 


\section{CHAPTER 1. INTRODUCTION}

\subsection{Problem Statement}

In order to reduce pollutant loadings nationwide, the U.S. Environmental Protection Agency (EPA), working in conjunction with the U.S. Department of Agriculture (USDA), are developing effluent management guidelines and standards for private and public aquaculture operations. Close proximity to eastern markets and an abundance of water resources gives the aquaculture industry in West Virginia tremendous potential for growth. Existing facilities must maximize their production to meet demands, compete with new operations, and be compliant with anticipated effluent standards.

\subsection{Objectives}

The objectives of this research were to (1) provide industry, State, and Federal stakeholders with baseline effluent water quality data specific to West Virginia facilities, in an effort to help concerned parties make informed decisions regarding impending regulations and (2) examine the potential to increase productivity based on effluent pollutant load and permit limitations. To attain these objectives, a water quality characterization was conducted at six anonymous facilities using flow-through design, rearing mostly rainbow trout (Oncorhynchus mykiss), that were selected based on various water sources, operation, size, and effluent

treatment. Pollutant load for each facility was compared with permit limitations to determine regulation impacts on production. 


\section{CHAPTER 2. BACKGROUND}

\subsection{Overview of Aquaculture in West Virginia}

Aquaculture is a growing industry both locally and nationwide for both recreation and food fish. An abundance of water resources, topography, and close proximity to eastern markets give West Virginia a unique opportunity for growth. Due to an abundance of groundwater sources, trout are the predominantly grown cool water fish in West Virginia. Nationally, commercial trout farms produce nearly 700,000 pounds annually (USDA, 1998).

\subsection{Culture Systems}

\subsubsection{Linear Units}

Raceways are linear fish culture units that have continuous flow for enhanced fish production and solids removal. Raceways are usually constructed of reinforced concrete, however earth, plastic, and metal are also used. Some additional characteristics of raceways include length:width ratio of 10:1, with a maximum depth of $0.61 \mathrm{~m}(2 \mathrm{ft}$.$) , water exchange rate$ of 4 exchanges per hour, and a linear water velocity of $0.033 \mathrm{~m} / \mathrm{sec}$ (Soderberg, 1995). The appropriate water velocity allows solids to settle at the rear of the culture units for easier cleaning.

Raceways are constructed in series or tiers and the number to tiers are based on dissolved oxygen (DO) and the accumulation of fish metabolic waste products (e.g. solids, dissolved nutrients, and dissolved gases). Clean-out plugs are usually located at the end of each culture unit for the removal of solids to a settling pond.

Presented in Figure 2.2.1.1 is a schematic of a typical raceway unit that has laminar flow for even solids distribution in the quiescent zones. 

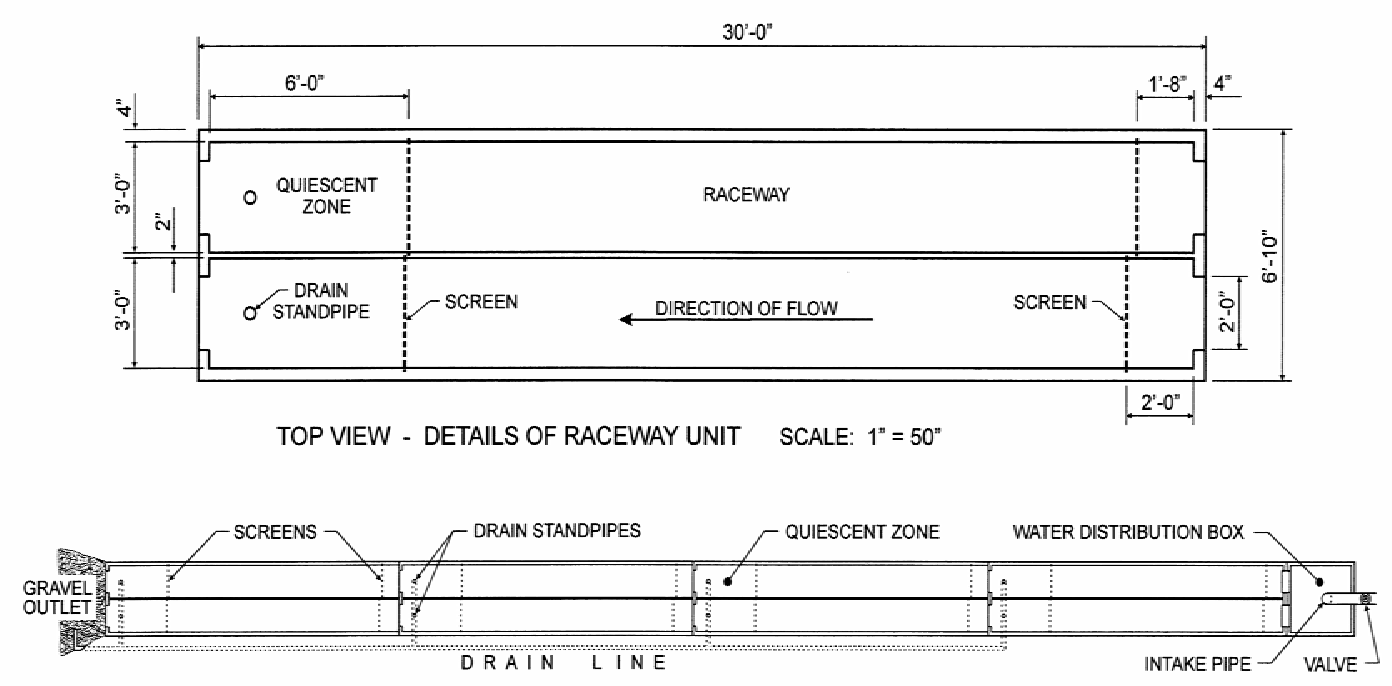

TOP VIEW

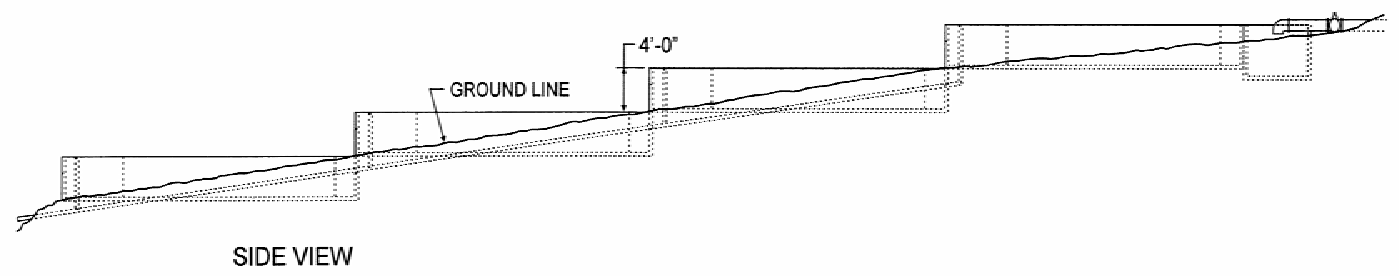

Figure 2.2.1.1. Schematic of typical linear fish culture unit.

\subsubsection{Circular Units}

Presented in Figure 2.2.2.1 is a schematic of a typical circular fish production unit. Circular fish rearing units are typically $0.61-0.91 \mathrm{~m}(2-3 \mathrm{ft}$.) in depth and $0.91-15.2 \mathrm{~m}(3-$ $50 \mathrm{ft}$. ) in diameter (Soderberg, 1995). Water enters the unit under pressure at one location along the edge of the unit and drains out the bottom. The injection of water causes a circular pattern flow of water in which velocity decreases near the center, resulting in the accumulation of solids at the bottom-center of the tank that produces a self-cleaning action. Circular units typically have velocities five to ten times higher that linear units, but exchange rates are usually only 2 exchanges per hour, limiting fish density (Colt and Tomasso, 2001). 


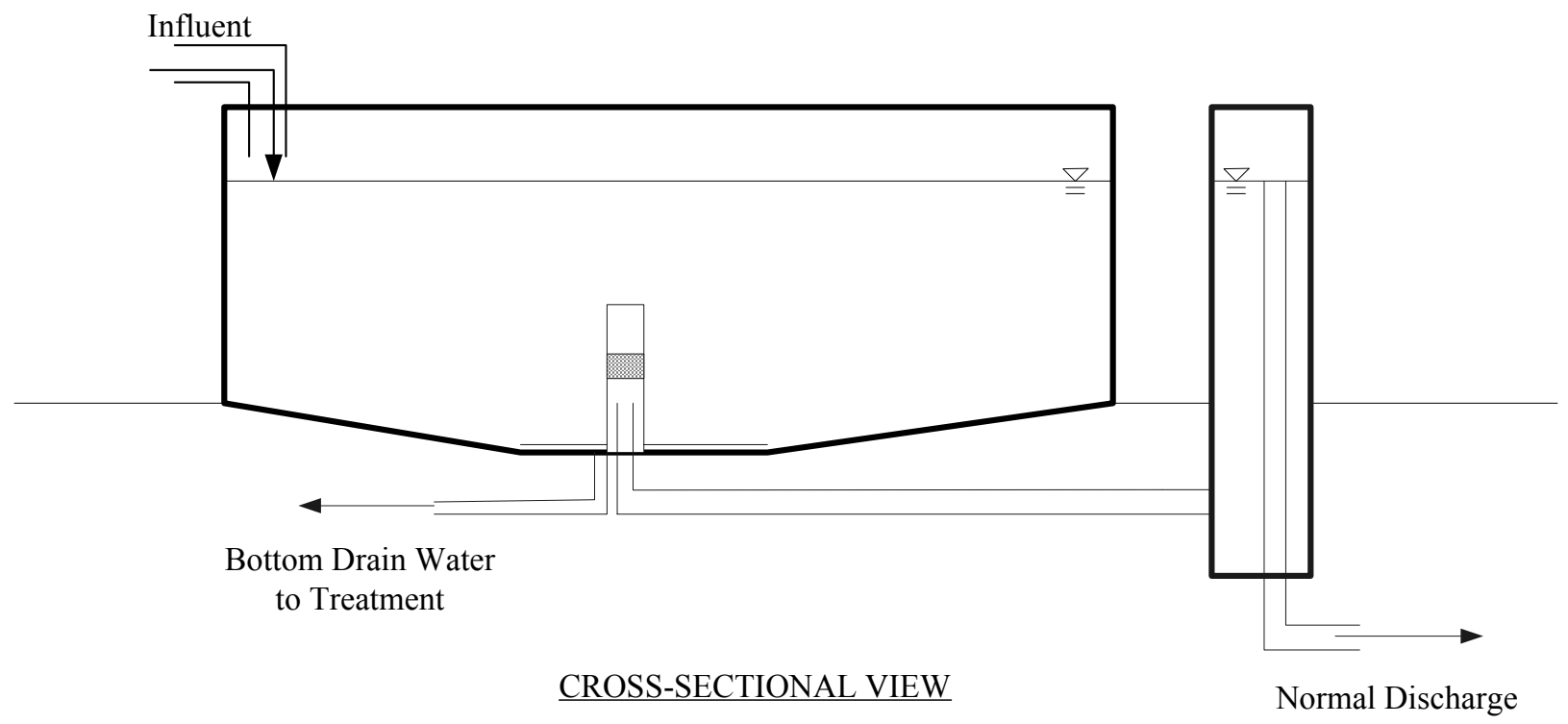

Figure 2.2.2.1. Schematic of typical circular fish culture unit.

\subsection{Water Resources}

The most important factor in successful fish production is the source water. Adequate quantity and quality of water are critical for fish culture operation and can be supplied by ground or surface sources (Colt and Tomasso, 2001).

\subsubsection{Groundwater}

Groundwater is the most desirable water source for trout production in West Virginia and the primary sources utilized are springs and mine waters. Groundwater is ideal for trout production because of both its quantity and quality.

West Virginia has 249 springs discharging $0.38-37.4 \mathrm{~m}^{3} / \mathrm{min}$. (100 - 9870 gal./min.), with a total discharge of $727 \mathrm{~m}^{3} / \mathrm{min}$ (192,000 gal./min.) (McColloch, 1986). Springs provide high quality water with relatively constant temperature and flow, but can be supersaturated with nitrogen and carbon dioxide gases that need removed before use (Wedemyer, 2001). 
Jenkins et al. (1995) investigated the used of discharge water from active and abandoned coal mines for the rearing of trout. Like traditional groundwater sources, mine waters have relatively constant year-round temperature and with acceptable water quality, can provide an important water source for trout production. Jenkins et al. (1995) concluded that $238 \mathrm{~m}^{3} / \mathrm{min}$ $(63,000 \mathrm{gal} . / \mathrm{min}$.) were adequate for trout production when pretreatment of water was not necessary.

\subsubsection{Surface Water}

Surface water is surface runoff as a direct result of precipitation and base flow from groundwater sources. In areas where precipitation is heavy and regular, surface water can be utilized for trout culture. However, high variability in precipitation can limit the utilization of surface waters for trout production due to variations in quantity and quality.

\subsection{Water Quality Criteria for Rainbow Trout}

Presented in Table 2.4.1 are the water quality criteria, relevant to this study, for rearing salmonids.

Table 2.4.1. Water Quality Criteria for Salmonid Production.

\begin{tabular}{llc}
\hline Parameter & $\begin{array}{c}\text { Upper limits for Continuous Exposure } \\
\text { and/or Tolerance Ranges }\end{array}$ & Reference \\
\hline Ammonia $\left(\mathrm{NH}_{3}\right)$ & $0.0125 \mathrm{mg} / \mathrm{L}$ (un-ionized form) & Soderberg, 1995 \\
Carbon dioxide & 0 to $10 \mathrm{mg} / \mathrm{L}$ & Meade, 1989 \\
Nitrate $\left(\mathrm{NO}_{3}^{-}\right)$ & 0 to $3.0 \mathrm{mg} / \mathrm{L}$ & Meade, 1989 \\
& $0.1 \mathrm{mg} / \mathrm{L}$ in soft water & Meade, 1989 \\
Nitrite $\left(\mathrm{NO}_{2}{ }^{-}\right)$ & $0.2 \mathrm{mg} / \mathrm{L}$ in hard water & IDEQ, 1998 \\
& $(0.03$ to $0.06 \mathrm{mg} / \mathrm{L}$ nitrite-nitrogen) & Meade, 1989 \\
pH & 6.5 to 8.0 & IDEQ, 1998 \\
Phosphorus & 0.01 to $3.0 \mathrm{mg} / \mathrm{L}$ & IDEQ, 1998 \\
Total Suspended Solids $(\mathrm{TSS})$ & $<80.0 \mathrm{mg} / \mathrm{L}$ & Meade, 1989 \\
Total Alkalinity (as CaCO & \\
Temperature & 10 to $400 \mathrm{mg} / \mathrm{L}$ & Piper, et al., 1982 \\
\hline
\end{tabular}




\subsubsection{Ammonia Nitrogen}

Ammonia is the primary nitrogenous waste production from fish metabolism and is toxic to fish in its un-ionized form. Ammonia is a gas that dissolves into water and forms either ammonium ion $\left(\mathrm{NH}_{4}^{+}\right)$or un-ionized ammonia $\left(\mathrm{NH}_{3}\right)$. The form of ammonia varies with $\mathrm{pH}$, temperature, and salinity, with increases in the toxic un-ionized form coinciding with increases in $\mathrm{pH}$ and temperature and decreases with increased salinity (Soderburg, 1995).

\subsubsection{Carbon Dioxide}

Carbon dioxide can occur naturally in some water sources used for fish production and can be added to water by fish respiration. Increased levels of carbon dioxide in culture water can lead to increased levels in the fish blood, resulting in carbonic acid production which can lower blood $\mathrm{pH}$. Systems with high environmental carbon dioxide levels require degassing before use in fish culturing (Hargreaves and Brunson, 1996).

\subsubsection{Nitrate}

Nitrate is produced by the bacterially-mediated oxidation of nitrite and is not considered toxic to fish in levels anticipated in aquaculture operations (Colt and Tomasso, 2001).

$$
\begin{aligned}
& \mathrm{NH}_{3}+1 \frac{1}{2} \mathrm{O}_{2} \rightarrow \mathrm{HNO}_{2}+\mathrm{H}_{2}+165 \mathrm{kcal} \\
& \mathrm{HNO} \rightarrow \mathrm{H}^{+}+\mathrm{NO}_{2}
\end{aligned}
$$

\subsubsection{Nitrite}

Nitrite is produced by the bacterially-mediated oxidation of ammonia. Typically, nitrite is further oxidized to nitrate, but in situations where ammonia oxidation exceeds nitrite oxidation, nitrite concentrations can become elevated to toxic levels.

$$
\mathrm{NO}_{2}+\frac{1}{2} \mathrm{O}_{2} \rightarrow \mathrm{NO}_{3}
$$

\subsection{5 $\mathrm{pH}$}


$\mathrm{pH}$ of culture waters influences the toxicity of ammonia, hydrogen sulfide, and metals and extremes can affect production negatively.

\subsubsection{Phosphorus}

Although little is known on the effects of dissolved phosphorus on aquatic animals, its impact in the environment is understood quite well. Phosphorus discharged from aquaculture operations can increase plant growth in the receiving waterbody and lead to advanced eutrophication; thus degrading water quality (Meade, 1989).

\subsubsection{Total Suspended Solids}

Suspended solids in aquaculture operations primarily consist of uneaten feed and fish fecal matter (biosolids). Suspended solids can harbor opportunistic pathogens, are associated with certain induced diseases, and can cause fin rot and gill damage (Wedemyer, 2001).

\subsubsection{Total Alkalinity}

Alkalinity is a measure of the capacity of water to neutralize a strong acid (Snoeyink and Jenkins, 1980). It impacts the initial $\mathrm{pH}$ of water and $\mathrm{pH}$ change due to carbon dioxide release by fish and the effects of photosynthesis, as well as ammonia toxicity.

\subsubsection{Temperature}

Temperature is one of the most important water characteristics in aquaculture operations, due to it's affect on fish metabolism, DO concentration, ionization of ammonia, decomposition, and photosynthesis. Temperatures outside the optimum range for a particular fish species can result in stress, decreased production efficiency, and possibly death (Colt and Tomasso, 2001)

\subsection{Aquaculture Effluent Pollutants}

Feed addition in aquaculture operations is the primary source of pollutants in process waters (Meade, 1989). Therefore, large facilities with more fish apply more feed, and thus have 
higher pollutant concentration in process waters before treatment. Uneaten feed and fish fecal matter are the two predominant results of the feed addition to operation waters, resulting in both dissolved and suspended waste. Both dissolved and suspended wastes contain organic $\left(\mathrm{BOD}_{5}\right)$ and nutrient (nitrogen and phosphorus) pollutants.

\subsubsection{Organic Pollutants}

Organic pollutants result from undigested feed and fish biosolids and can be in the dissolved or suspended state. The most common parameter associated with organic pollutants in aquaculture effluents is the 5-day biochemical oxygen demand $\left(\mathrm{BOD}_{5}\right)$, which is a measure of the oxygen demand of microorganisms to degrade organic matter.

\subsubsection{Nutrient Pollutants}

The two primary nutrient pollutants in aquaculture waters are nitrogen $(\mathrm{N})$ and phosphorus (P) and are of concern because of their detrimental impacts on the environment. An abundance of $\mathrm{N}$ and $\mathrm{P}$ in waters can lead to eutrophication (Selong and Helfrich, 1998). Like all other aquaculture pollutants, the source of nutrients is feed and its metabolic residuals. Figure 2.5.2.1 illustrates the fate of $\mathrm{N}$ and $\mathrm{P}$ as they enter an aquaculture operation in the form of feed. 


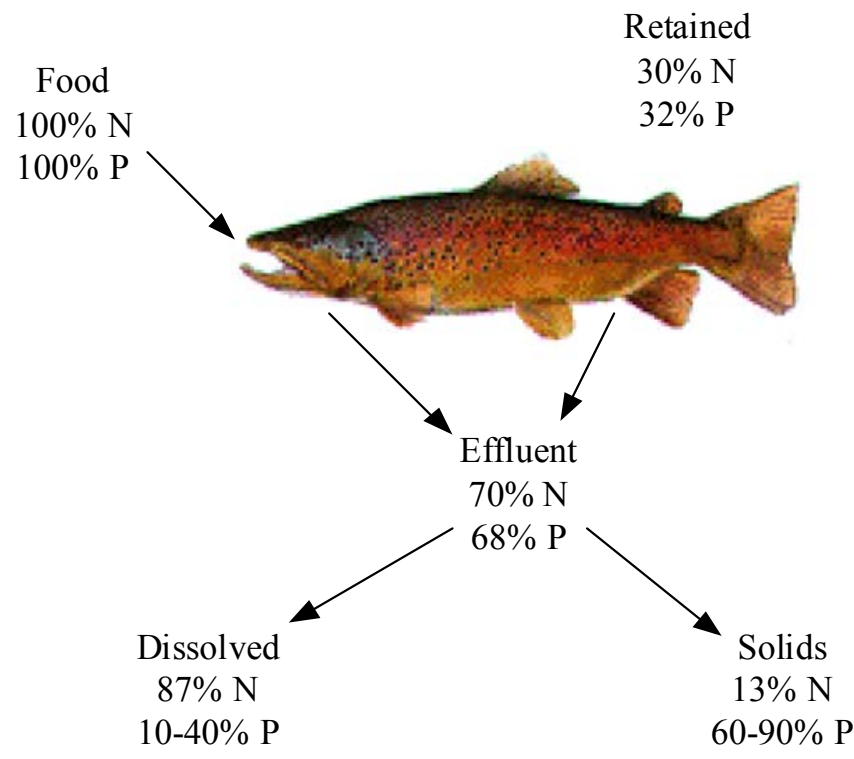

Figure 2.5.2.1. Fate of feed nitrogen $(\mathrm{N})$ and phosphorus $(\mathrm{P})$. Adapted from Ramseyer and Garling, 1997.

\subsubsection{Nitrogen}

Nitrogen in feed is primarily in the form of amino acids, the building blocks of proteins. The sources of nitrogen excreted by fish include undigested and unabsorbed dietary protein, sloughed intestinal cells, amino acids absorbed in amounts greater than the fish can utilize, and degraded metabolic products (Ramseyer and Garling, 1997). Only 30\% of consumed feed nitrogen is retained by the fish, while the remaining $70 \%$ is excreted by the lungs as ammonia gas and as biosolids. Of excreted nitrogen, $87 \%$ is in the dissolved form of gaseous ammonia, while only $13 \%$ is in the suspended form, which makes $\mathrm{N}$ difficult to remove from wastewaters (Ramweyer and Garling, 1997).

\subsubsection{Phosphorus}

Phosphorus availability in fish feeds depends greatly upon the source, with rice bran and blood meal ranging from 19 to $81 \%$, respectively. Feeds that contain highly available forms of phosphorus will excrete less to the environment. Only $32 \%$ of consumed feed phosphorus is 
retained by the fish, while the remaining $68 \%$ is excreted in dissolved and suspended forms. Of excreted phosphorus, $10-40 \%$ is in the dissolved form, while $60-90 \%$ is in the suspended form, making phosphorus more easily controlled with proper solids management (Ramseyer and Garling, 1997).

\subsection{Regulation}

\subsubsection{Federal Regulation}

Since aquaculture wastewaters are discharged into receiving waterbodies, they are regulated by the Federal Clean Water Act (CWA) of 1977. Federal regulation is primarily enforced by the U.S. Environmental Protection Agency (EPA). As in many states, West Virginia is delegated to regulate aquaculture discharges, through the West Virginia Department of Environmental Protection (WVDEP).

\subsubsection{State Regulation}

Current West Virginia regulation requires a National Pollutant Discharge Elimination System (NPDES) permit for coldwater aquatic animals that discharge more than 30 days per year or produce above 9,072 kg (20,000 lbs.) per year (Ewart, 1995). Facilities that meet this criterion are classified as concentrated animal feeding operations (CAFO).

\subsection{Effluent Management}

The control of pollutants in aquaculture effluents requires reducing the amount of dissolved and suspended waste produced in the system. Dissolved pollutants are primarily controlled through diet optimization and to a lesser extent proper solids management. Suspended pollutants in aquaculture effluents are controlled through the use of various sedimentation and filtration processes.

\subsubsection{Dissolved Pollutant Management}


Ingredients in fish feed that are easily digested is the primary treatment for dissolved pollutants. Cho (1997), reported the use of a highly digestible, nutrient-dense (HND) diet yielded outputs less than $190 \mathrm{~kg}$ solid waste and $3 \mathrm{~kg}$ phosphorus per metric ton of salmonid fish produced, while a conventional diet yielded 240 and $4 \mathrm{~kg}$, respectively.

\subsubsection{Suspended Pollutant Management}

Rapid and permanent removal of suspended solids from process waters is essential to reduce pollutant load and to prevent leaching of pollutants to the dissolved state. Sedimentation for the removal of suspended waste from aquaculture effluent is the most common and economical method in the United States (Hinshaw, 2002). There are three primary types of settling basins used to treat aquaculture effluent: quiescent zones, off-line settling (OLS) basins, and full-flow settling basins.

Quiescent zones are areas at the end of each raceway that are barred from fish and allow solids to settle, where they can be removed by the use of a stand pipe to an OLS basin.

OLS basins are settling areas that receive a small fraction of the total system flow and contain concentrated amounts of suspended waste. Most circular tank systems employ OLS basins as their suspended pollutant treatment method.

Full-flow settling basins receive the total flow of the aquaculture operation and are generally used for flow less than $283 \mathrm{~L} / \mathrm{sec}$ (Hinshaw, 2002). 


\section{CHAPTER 3. INVESTIGATIVE APPROACH}

\subsection{Experimental Design}

\subsubsection{Site Selection}

In order to provide effluent data on a broad range of operations, six (6) West Virginia aquaculture facilities were selected for participation in the study. The identity of all participants remained anonymous. To enable inter-facility comparison, all participating facilities were of flow-through design and reared primarily rainbow trout (Oncorhynchus mykiss); however, limited numbers of brown trout (Salmo trutta) and brook trout (Salvelinus fontinalis) were also raised at all but two (2) facilities. Site selection was based on water source, facility size, effluent treatment, and operator feeding practices.

Table 3.1. Site characteristics of the six facilities.

\begin{tabular}{|c|c|c|c|c|c|c|}
\hline \multirow{2}{*}{ Characteristic } & \multicolumn{6}{|c|}{ Facility } \\
\hline & A & B & $\mathrm{C}$ & $\mathrm{D}$ & $\mathrm{E}$ & $\mathrm{F}$ \\
\hline Water Source & Spring & Spring & Spring & Spring & Mine & Mine \\
\hline $\begin{array}{l}\text { Annual Feed } \\
\text { Mass }\end{array}$ & $>18,144 \mathrm{Kg}$ & $<9,072 \mathrm{Kg}$ & $<9,072 \mathrm{Kg}$ & $<9,072 \mathrm{Kg}$ & $>18,144 \mathrm{Kg}$ & $\begin{array}{c}9,072 \text { to } \\
18,144 \mathrm{Kg}\end{array}$ \\
\hline $\begin{array}{l}\text { Annual Fish } \\
\text { Production }\end{array}$ & $90,718 \mathrm{Kg}$ & $13,608 \mathrm{Kg}$ & $13,608 \mathrm{Kg}$ & $<9,000 \mathrm{Kg}$ & $57,000 \mathrm{Kg}$ & $36,000 \mathrm{Kg}$ \\
\hline Fish lbs./gpm & 153 & 39.3 & 93.8 & 39.4 & 68.9 & 67.7 \\
\hline $\begin{array}{l}\text { Effluent } \\
\text { Treatment }\end{array}$ & $\begin{array}{l}\text { Sediment } \\
\text { Pond }\end{array}$ & $\begin{array}{l}\text { Sediment } \\
\text { Basin }\end{array}$ & $\begin{array}{l}\text { Sediment } \\
\text { Pond }\end{array}$ & None & OLS Pond & OLS Pond \\
\hline $\begin{array}{l}\text { Feeding } \\
\text { Practice }\end{array}$ & $\begin{array}{c}\text { Hand } \\
\text { (measured) }\end{array}$ & $\begin{array}{c}\text { Hand } \\
\text { (measured) }\end{array}$ & $\begin{array}{l}\text { Automated } \\
\text { (pull string) }\end{array}$ & $\begin{array}{l}\text { Automated } \\
\text { (pull string) }\end{array}$ & $\begin{array}{c}\text { Hand } \\
\text { (measured) }\end{array}$ & $\begin{array}{c}\text { Hand } \\
\text { (measured) }\end{array}$ \\
\hline $\begin{array}{l}\text { Feed Type } \\
(\mathrm{CP} / \mathrm{F})\end{array}$ & $38 / 11$ & $40 / 23$ & $40 / 23$ & $42 / 16$ & $38 / 11$ & $38 / 11$ \\
\hline
\end{tabular}

\subsubsection{Water Source}

Facilities were selected for inclusion in this study to encompass a range of water sources for trout production. Water sources utilized at the selected sites included natural springs and mine pool waters. 


\subsubsection{Facility Size}

National Pollutant Discharge Elimination System (NPDES) Permits have been issued to facilities based on the annual rate of feed applied, therefore, facility "size" was based on this criterion. Three (3) sizes of facilities were selected for this study:

1. Facilities applying $>40,000 \mathrm{lbs}(18,144 \mathrm{~kg})$. feed annually.

2. Facilities applying 20,000 to $40,000 \mathrm{lbs}$. $(9,072$ to $18,144 \mathrm{~kg})$ feed annually.

3. Facilities applying $<20,000 \mathrm{lbs} .(9,072 \mathrm{~kg})$ feed annually (Ewart et al. 1995).

\subsubsection{Effluent Treatment}

Given varying water resources employed, size, and economic viability of the selected operations, a wide range of effluent treatment options were observed. Treatment strategies ranged from direct discharge into receiving water bodies to more complex designs involving sedimentation and biofiltration. The wide range of treatment options at study facilities enabled an assessment of the benefits of additional treatment methods on production and effluent quality.

\subsubsection{Operator Feeding Practices}

Facilities were also characterized according to the type of feed, quantity of feed, and feeding mechanism employed. The type of feed utilized was either conventional or "high yield", while the feeding mechanism was either automatic or manual.

\subsubsection{Description of Research Sites}

\subsubsection{Facility $A$}

A schematic of Facility A is presented in the following process flow diagram (PFD). 


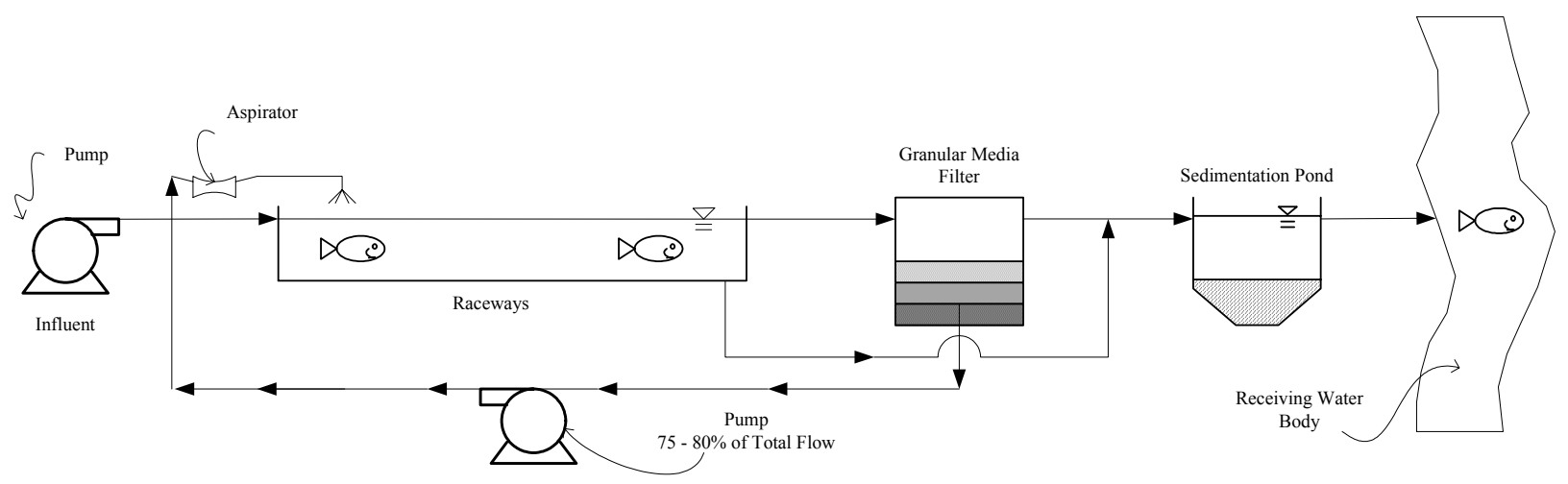

Figure 3.1.1 Process Flow Diagram of Facility A. Note: Facility has 40 raceways.

The facility was a West Virginia State owned hatchery that supplied $\sim 90,000 \mathrm{~kg}$ of trout for stocking of State waters.

Water was pumped from a nearby spring that had an average flow of 4,542 liters per minute. The facility had forty (40) concrete raceways (30.5 m x $2.44 \mathrm{~m} \times 0.762 \mathrm{~m})$ in which fingerlings through brood stock resided. Approximately $2,268 \mathrm{~m}^{3}$ of production volume was available. Quiescent zones at the end of each raceway were employed to remove settleable solids from the process water. Stand pipes in the quiescent zones allowed solids removal to the sedimentation pond for treatment. Six (6) furnace-slag granular media filters $(15.3 \mathrm{~m} \mathrm{x} 4.65 \mathrm{~m})$ were used to re-circulate $75-80 \%$ of the total flow into the head-works of the facility. A photograph of the granular media filters of Facility A is presented in Figure 3.1.2. Recirculation water was aerated by an aspirator system, presented in Figure 3.1.3. Water from the quiescent zones and backwash from periodic cleaning of the granular media filters passed through an effluent sedimentation pond before being discharged into the receiving water body. 


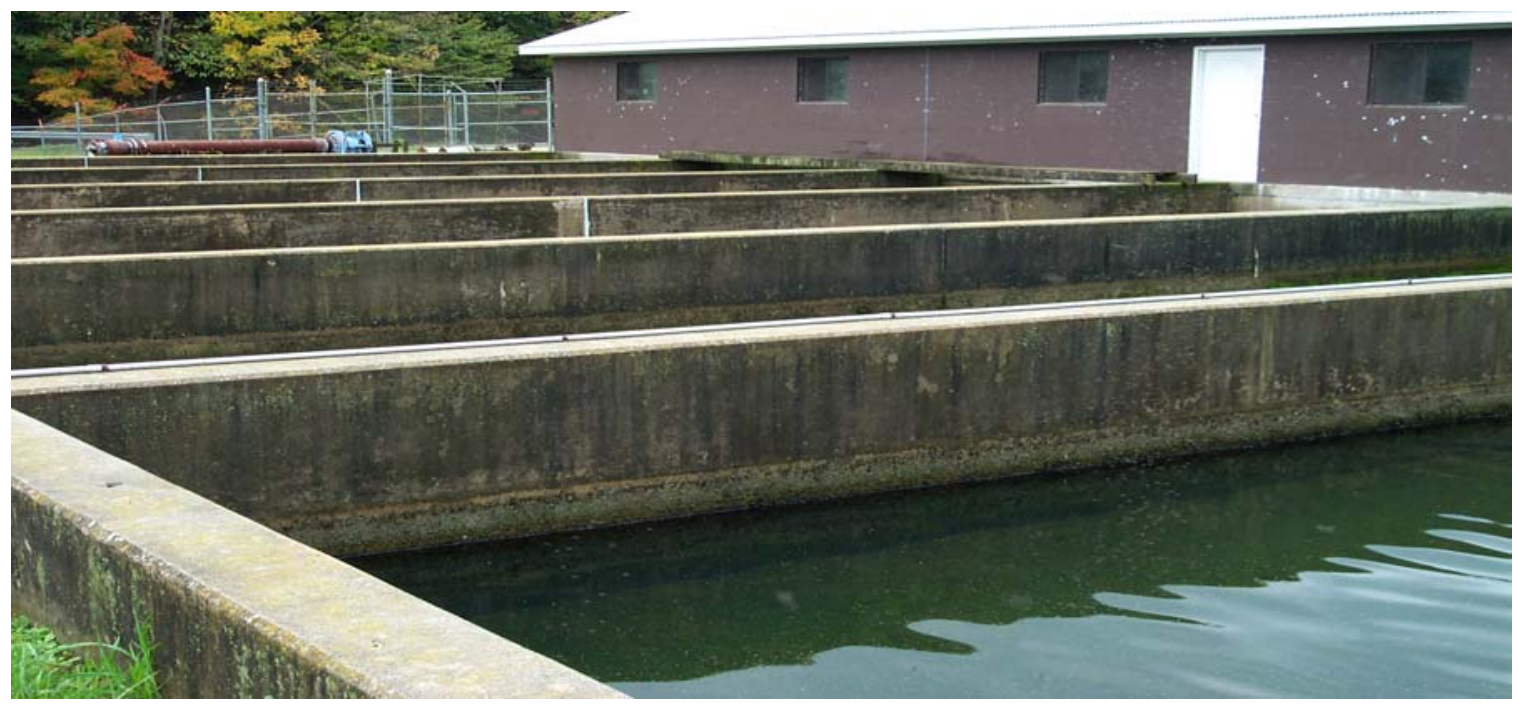

Figure 3.1.2 Photograph of Granular Media Filters of Facility A.

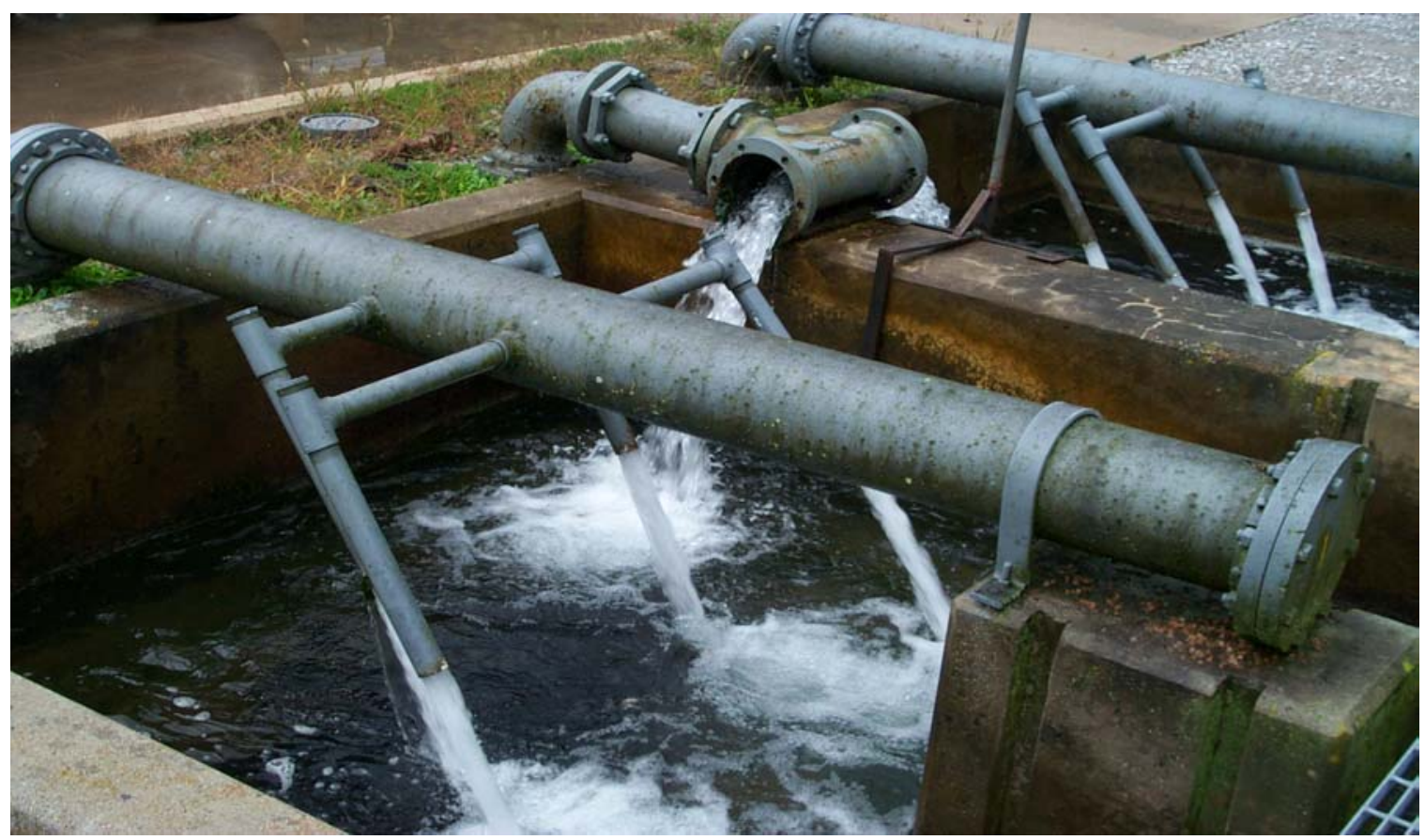

Figure 3.1.3 Photograph of Aspirator System for Aeration at Facility A.

A summary of water quality parameters and regulatory limits required by the NPDES Permit for Facility A are presented in Table 3.2. The facility's effluent was regulated by an NPDES Permit, which called for the monitoring of flow rate, five-day biochemical oxygen demand $\left(\mathrm{BOD}_{5}\right)$, total suspended solids (TSS), ammonia nitrogen $\left(\mathrm{NH}_{3}\right)$, settleable solids (SS), $\mathrm{pH}$, and dissolved oxygen (DO). The $\mathrm{BOD}_{5}, \mathrm{TSS}$, and $\mathrm{NH}_{3}$ were monitored once per month by 
composite samples, while $\mathrm{pH}, \mathrm{DO}$, and $\mathrm{SS}$ were monitored through grab sample analysis. Flow rates were estimated.

Table 3.2 NPDES Permit Requirements for Facility A.

\begin{tabular}{|c|c|c|c|c|}
\hline \multirow[b]{2}{*}{ Parameter } & \multicolumn{2}{|c|}{ (Mass Load) Kg/day } & \multicolumn{2}{|c|}{ (Concentration) $\mathrm{mg} / \mathrm{L}$} \\
\hline & Avg Monthly & Max Daily & Avg Monthly & Max Daily \\
\hline $\mathrm{BOD}_{5}$ & $\begin{array}{c}432.35 \\
(196.11 \mathrm{lbs} / \text { day })\end{array}$ & $\begin{array}{c}864.70 \\
(392.2 \mathrm{lbs} / \text { day })\end{array}$ & 30 & 60 \\
\hline TSS & $\begin{array}{c}432.35 \\
(196.11 \mathrm{lbs} / \text { day })\end{array}$ & $\begin{array}{c}864.70 \\
(392.2 \mathrm{lbs} / \text { day })\end{array}$ & 30 & 60 \\
\hline TAN & N/A & $\begin{array}{c}150.55 \\
(62.3 \mathrm{lbs} / \text { day })\end{array}$ & N/A & $10.44^{\dagger}$ \\
\hline $\mathrm{SS}$ & $\mathrm{N} / \mathrm{A}$ & $\mathrm{N} / \mathrm{A}$ & $\mathrm{N} / \mathrm{A}$ & 0.2 \\
\hline DO & N/A & N/A & Minimum 6.0 & Minimum 6.0 \\
\hline $\mathrm{pH}$ & $\mathrm{N} / \mathrm{A}$ & $\mathrm{N} / \mathrm{A}$ & $6-9$ & $6-9$ \\
\hline Flow & $\mathrm{N} / \mathrm{A}$ & N/A & N/A & Monitor mgd \\
\hline
\end{tabular}

\subsubsection{Facility $B$}

A schematic of Facility B is presented in the following process flow diagram.

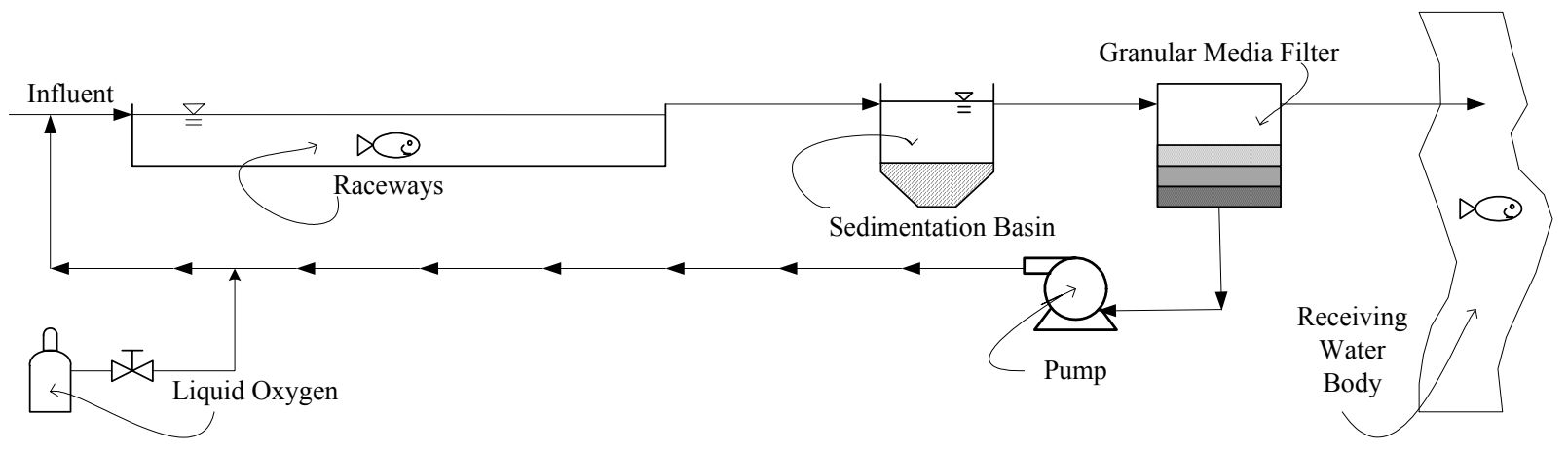

Figure 3.1.4 Process Flow Diagram of Facility B.

The facility produced $\sim 13,608 \mathrm{~kg}$ of primarily rainbow trout, with a small amount of brook and brown trout. High yield feeds were administered manually one [1] to two [2] times daily. The primary market for this facility was private stocking for game fishing.

Water flowed from the spring under gravity into the facility headbox, where it was split into eight [8] concrete raceways (2.44 m x $13.7 \mathrm{~m} \times 0.61 \mathrm{~m})$ and three [3] earthen raceways (2@) 
$4.57 \mathrm{~m} \times 13.7 \mathrm{~m} \times 0.61 \mathrm{~m}$ and $1 @ 3.05 \mathrm{~m} \times 30.5 \mathrm{~m}$ x $0.61 \mathrm{~m})$. Facility B had an approximate production volume of $296 \mathrm{~m}^{3}$. Water then flowed through a concrete sedimentation basin $(13.9 \mathrm{~m}$ x $4.92 \mathrm{~m} \mathrm{x} 1.22 \mathrm{~m}$ ) for solids removal. Two [2] crusher-run limestone granular media filters (10.7 m x $13.9 \mathrm{~m} \times 1.22 \mathrm{~m}$ ) were operated $3-6$ months per year and able to create $4,361 \mathrm{~m}^{3} /$ day for recirculation. A photograph of the sedimentation basin and granular media filters of Facility B is presented in Figure 3.1.5. During operation of the granular media filter, the operator had the option to incorporate liquid oxygen into the recirculation water.

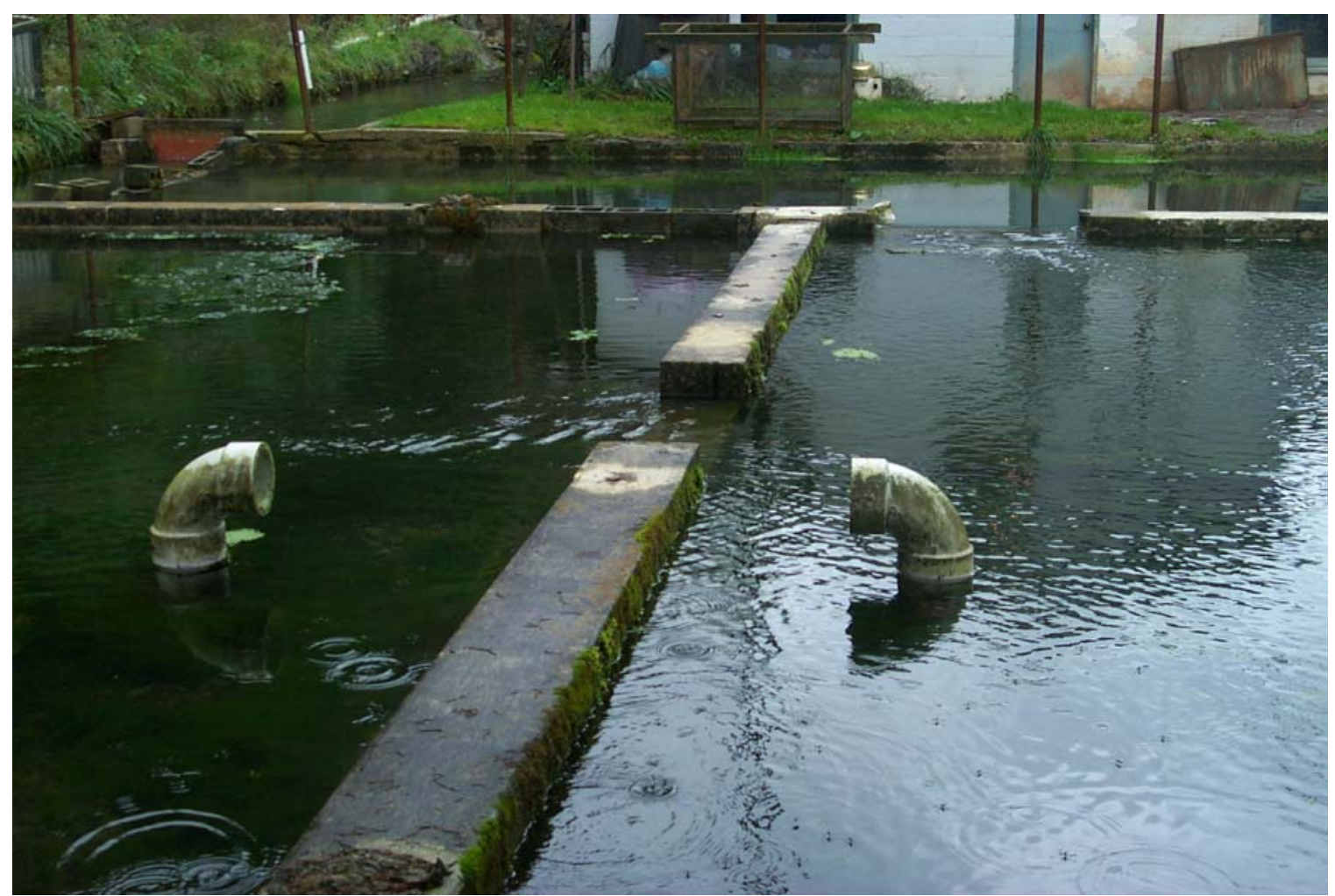

Figure 3.1.5 A Photograph of the Sedimentation Basin and Granular Media Filters of Facility B.

A summary of water quality parameters and regulatory limits required by the NPDES Permit for Facility B are presented in Table 3.2. The facility's effluent was also regulated by an NPDES Permit, which called for the semi-annual monitoring of flow rate, $\mathrm{BOD}_{5}, \mathrm{TSS}, \mathrm{NH}_{3}, \mathrm{SS}$, 
$\mathrm{pH}$, and $\mathrm{DO}$. The $\mathrm{BOD}_{5}, \mathrm{TSS}$, and $\mathrm{NH}_{3}$ were monitored once per month by composite samples, while $\mathrm{pH}, \mathrm{DO}$, and $\mathrm{SS}$ were monitored by grab samples. Flow rates were estimated.

Table 3.3 NPDES Permit Requirements for Facility B.

\begin{tabular}{lcccc} 
& \multicolumn{2}{c}{ (Mass Load) lbs/day } & \multicolumn{2}{c}{ (Concentration) mg/L } \\
Parameter & Avg Monthly & Max Daily & Avg Monthly & Max Daily \\
\hline BOD $_{5}$ & Monitor Only & Monitor Only & Monitor Only & Monitor Only \\
$\mathrm{TSS}$ & Monitor Only & Monitor Only & Monitor Only & Monitor Only \\
$\mathrm{NH}_{3}$ & N/A & Monitor Only & N/A & Monitor Only \\
$\mathrm{SS}$ & N/A & N/A & N/A & Monitor Only \\
$\mathrm{DO}$ & N/A & N/A & Monitor Only & Monitor Only \\
pH & N/A & N/A & Monitor Only & Monitor Only \\
Flow & N/A & N/A & N/A & Monitor mgd \\
\hline
\end{tabular}

\subsubsection{Facility $C$}

A schematic of facility $\mathrm{C}$ is presented in the following process flow diagram.

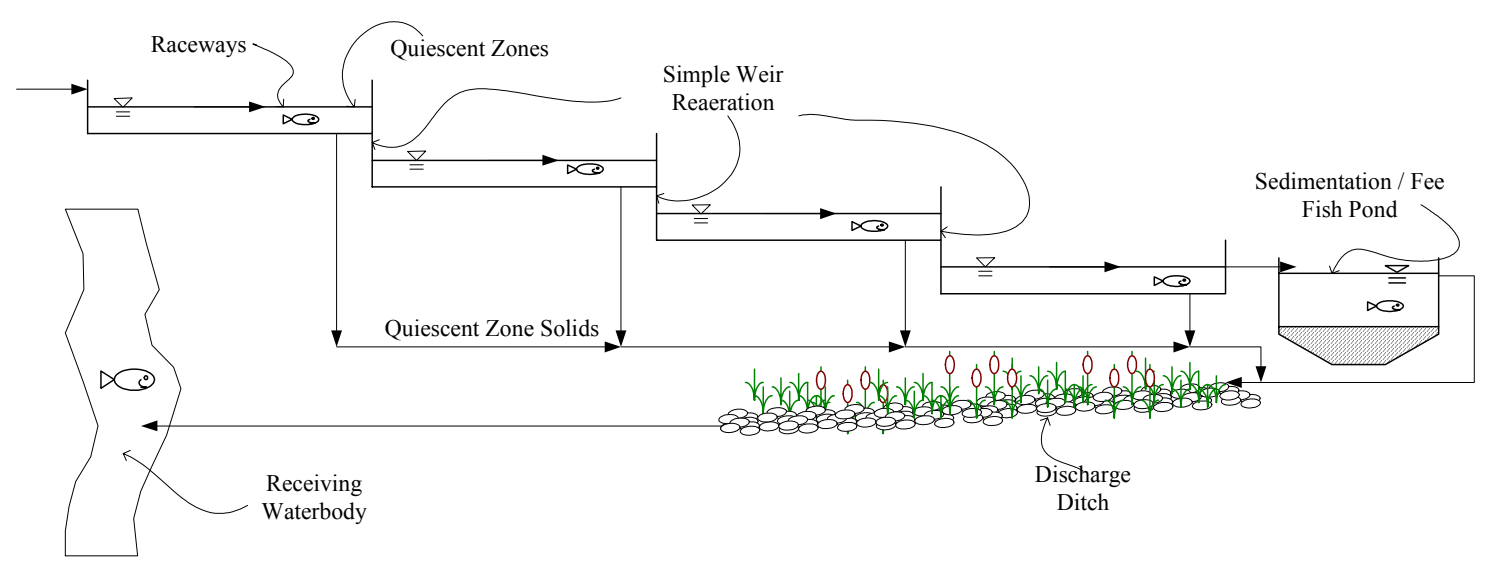

Figure 3.1.6 Process Flow Diagram of Facility C.

The operation was gravity fed by spring water, and the headloss of the site allowed for gravity reaeration between raceways. High yield feeds were administered both mechanically (pull string) and manually (hand measured) one [1] to two [2] times daily. The facility produced $\sim 13,608 \mathrm{~kg}$ of rainbow, brook, and brown trout, with rainbow being the predominant species. The primary market for this facility was an adjacent fee fishing operation. 
Water flowed by gravity from the spring to a headbox where it was spit into two [2] parallel raceway systems consisting of two [2] (9.0 m x $1.83 \mathrm{~m} \times 0.53 \mathrm{~m})$, two [2] (15.3 $\mathrm{m} \times 1.83$ $\mathrm{m} \times 0.53 \mathrm{~m})$, two [2] (16.7 $\mathrm{m} \times 1.83 \mathrm{~m} \times 0.53 \mathrm{~m})$, and two [2] (11.9 m x $1.83 \mathrm{~m} \times 0.53 \mathrm{~m})$ concrete raceways, totaling eight [8], with quiescent zones at the end of each for solids removal. A photograph of the raceway system at Facility $\mathrm{C}$ is presented in Figure 3.1.7. The facility had a production volume of $102.5 \mathrm{~m}^{3}$ in the raceway system and $6,170 \mathrm{~m}^{3}$ in the sedimentation / fee fish pond. Headloss at the site enabled considerable rearation between production units $\left(\mathrm{h}_{\mathrm{L}} \sim 1.0\right.$ m). Water from the raceway system was then passed through a sedimentation pond before being discharged into an adjacent vegetated discharge ditch that carried the effluent to the receiving water body. Solids from the quiescent zones were periodically removed through stand pipes and discharged into the vegetated discharge ditch. Facility $\mathrm{C}$ is not regulated by an NPDES Permit.

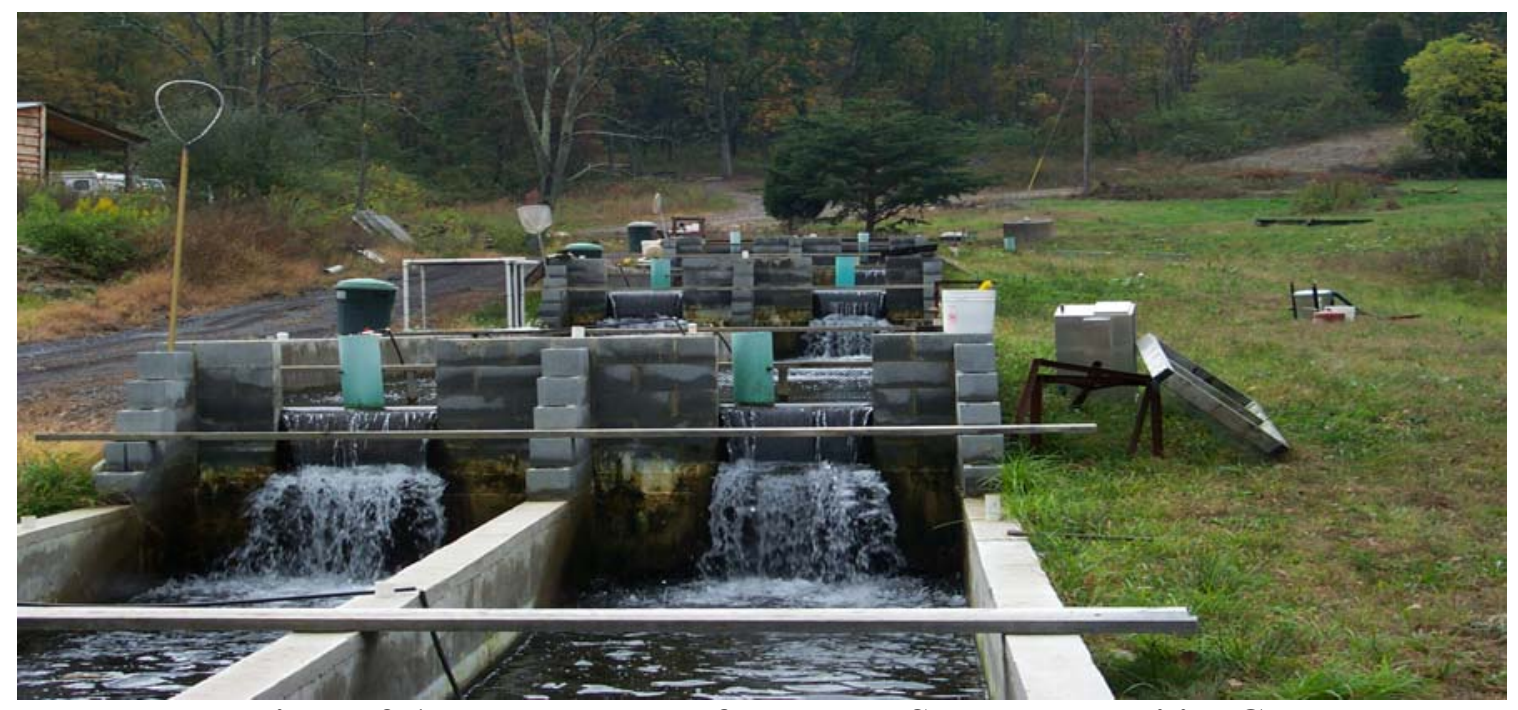

Figure 3.1.7 Photograph of Raceway System at Facility C.

\subsubsection{Facility D}

A schematic of facility $\mathrm{C}$ is presented in the following process flow diagram. 


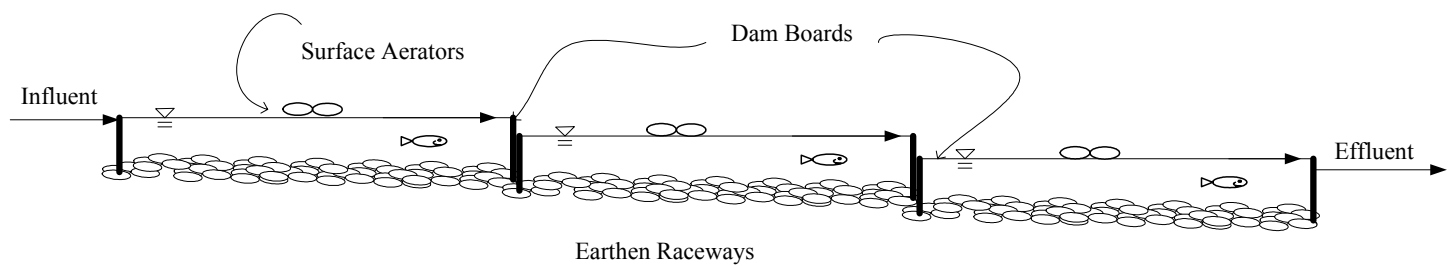

Figure 3.1.8 Process Flow Diagram of Facility D. Note: Facility has 5 containment areas.

Facility D used the existing stream channel as raceways, with holding areas separated by gates. High yield feed was delivered mechanically (pull string) and manually (hand measured) one [1] to two [2] times daily. The facility produced $<9,000 \mathrm{~kg}$ of rainbow, brook, and brown trout, with rainbow being the predominant species. The market for Facility D was private stocking for game fishing.

Water from an adjacent spring was collected in a culvert pipe and discharged into the earthen raceway system. Five [5] holding areas were separated by gates where oxygen was increased minimally by gravity aeration, due to small head loss. Floating impeller aerators were employed to increase dissolved oxygen during low-flow conditions. A photograph of the floating impeller aerators is presented in Figure 3.1.9. There was no effluent treatment in the operation; hence effluent from the facility flowed directly into the receiving water body. Facility D is not regulated by an NPDES Permit. 


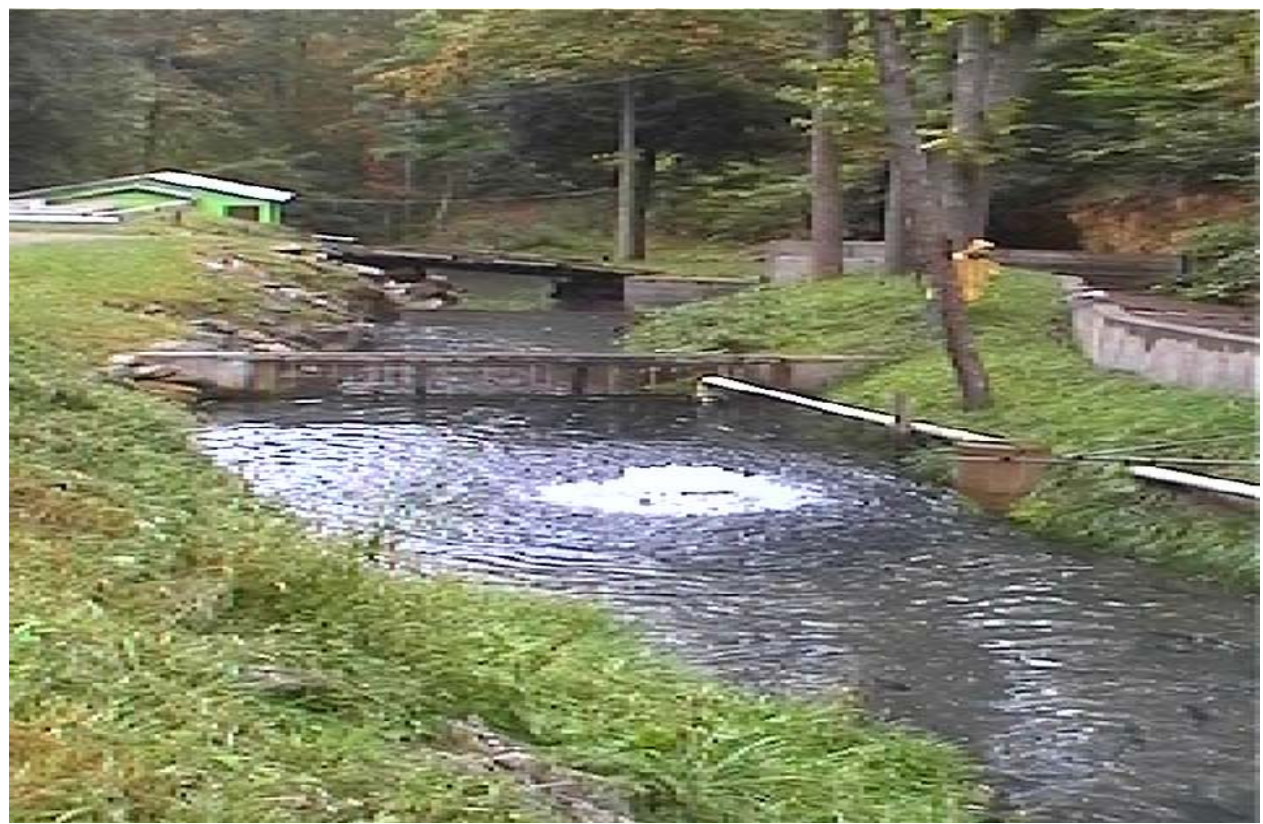

Figure 3.1.9 Photograph of Surface Aerators at Facility D.

\subsubsection{Facility $E$}

A schematic of facility $\mathrm{E}$ is presented in the following process flow diagram.

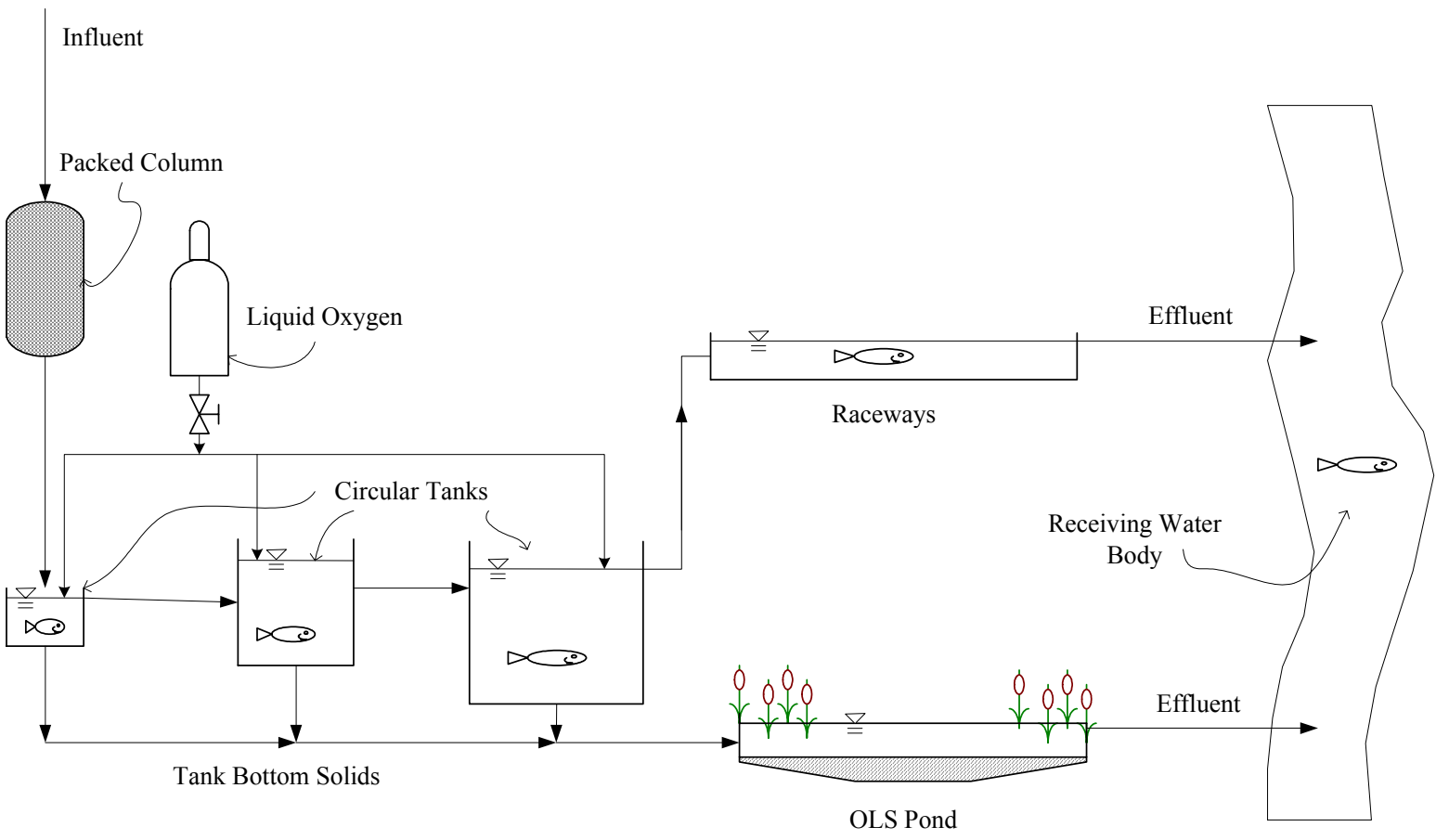

Figure 3.1.10 Process Flow Diagram of Facility E. Note: Facility has multiple tanks of each size. 
The operation was gravity fed water from a deep mine pool that needed to be de-gassed to remove excess carbon dioxide $\left(\mathrm{CO}_{2}\right)$ and increase the DO concentration. High yield feeds were administered manually (hand measured) three [3] times daily. The facility produced approximately $57,000 \mathrm{~kg}$ rainbow trout annually. The primary market for facility E was human consumption, with restaurants being the main purchaser.

Water from the deep mine drain flowed by gravity to a packed column to remove $\mathrm{CO}_{2}$ and increase DO. A photograph of the packed column in presented is Figure 3.1.11.

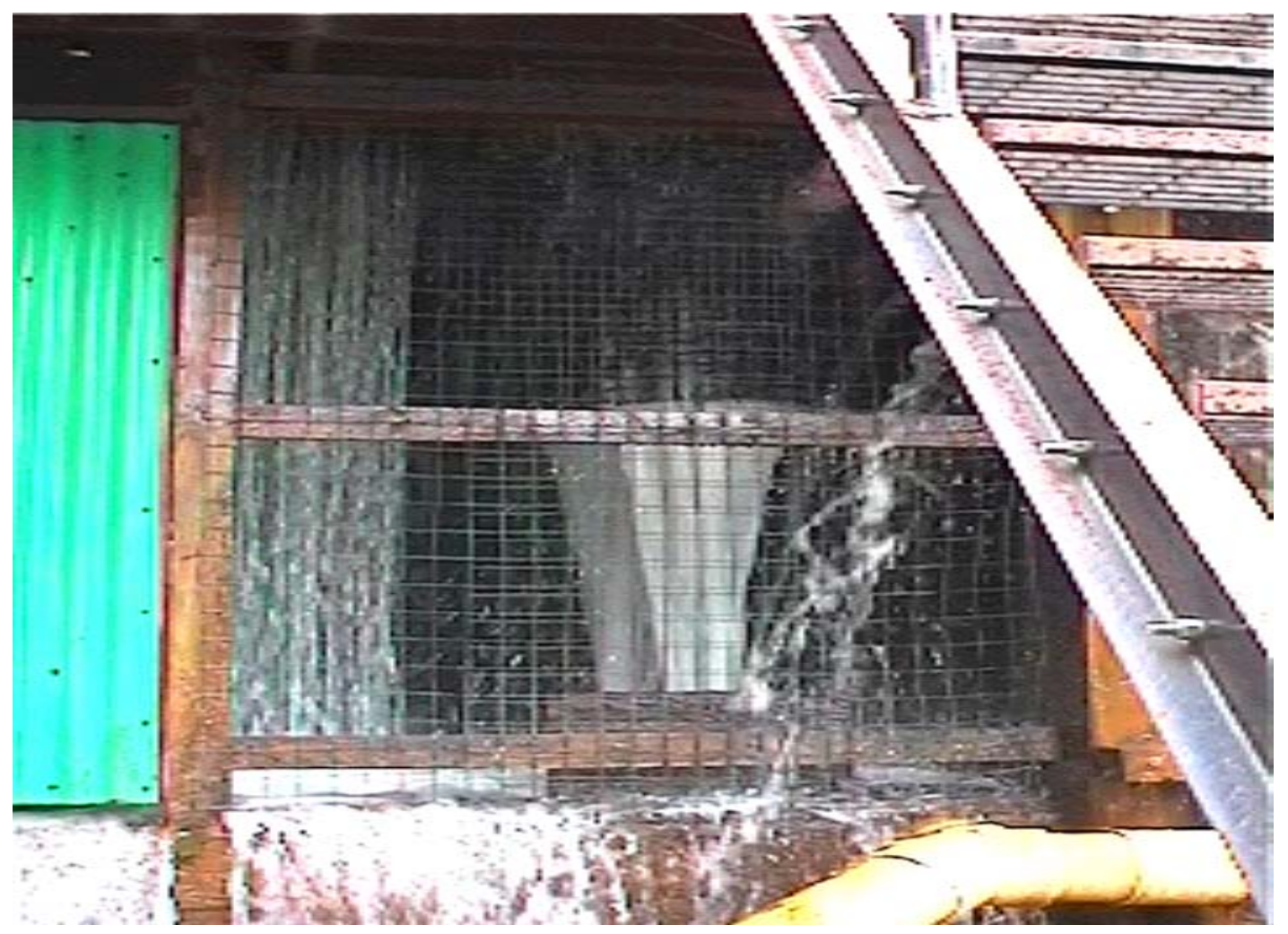

Figure 3.1.11 Packed Aeration Column

Water was then distributed through parallel delivery piping to $24-1.4 \mathrm{~m}^{3}, 48-2.8 \mathrm{~m}^{3}, 10-37.9$ $\mathrm{m}^{3}$, and $12-75.8 \mathrm{~m}^{3}$ circular tanks. Liquid oxygen was fed in the influent of each tank to increase DO levels. A photograph of the liquid oxygen tanks is presented in Figure 3.1.12. The 
discharge from all the tanks was then distributed to a parallel raceway system where trout were held for final grow-out and distribution. Water from the raceway system was then discharged to the receiving water body. Stand pipes in each tank in the system drained to an off-line sedimentation (OLS) pond, in which solids were settled. The supernatant was discharged to the receiving water body. The facility did not have an NPDES Permit.

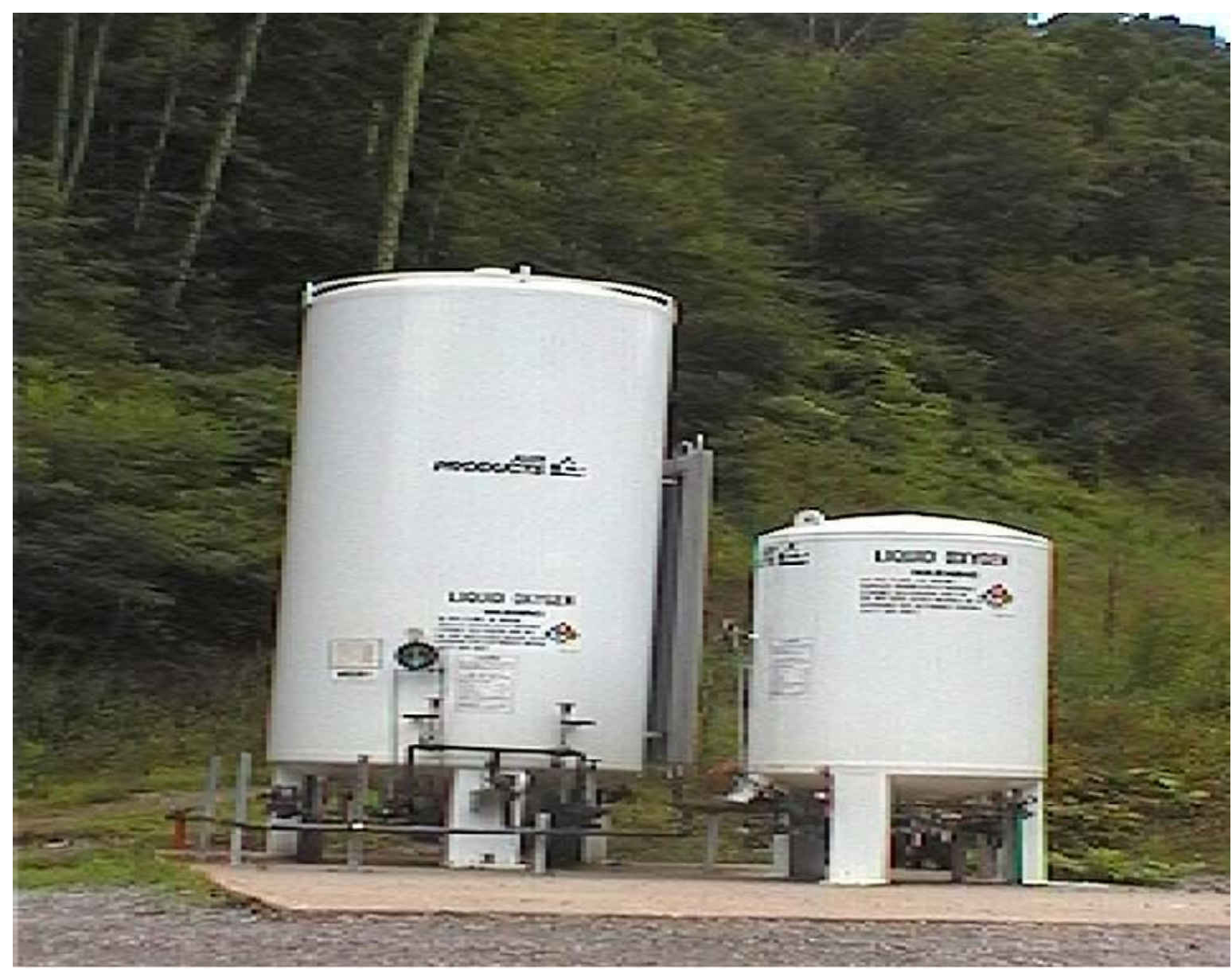

Figure 3.1.12 Liquid Oxygen Tanks of Facility E.

\subsubsection{Facility $F$}

A schematic of facility $\mathrm{F}$ is presented in the following process flow diagram. 


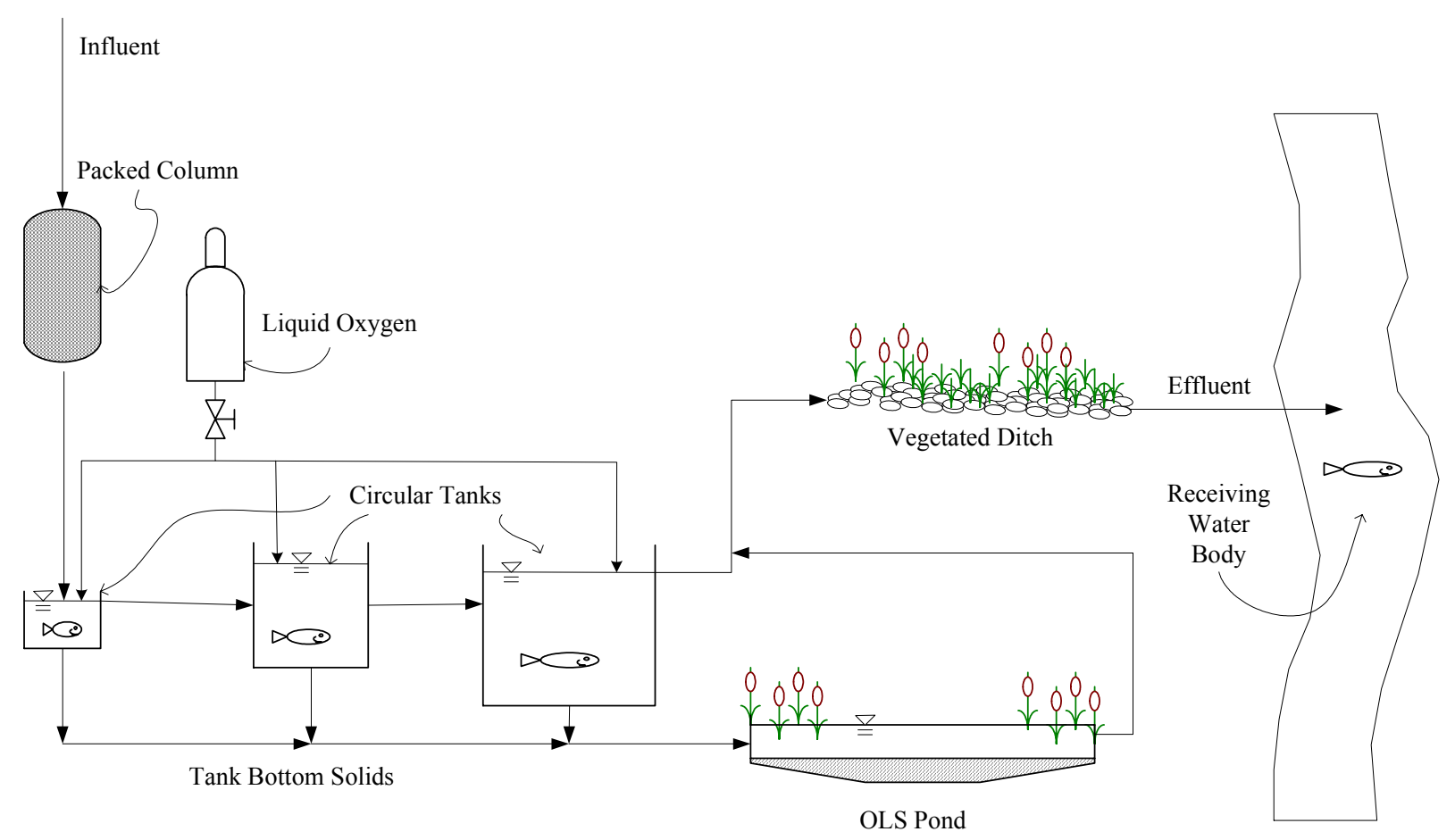

Figure 3.1.13 Process Flow Diagram of Facility F. Note: Facility has multiple tanks of each size.

The operation was gravity fed water from a deep mine pool that needed to be de-gassed to remove excess carbon dioxide $\left(\mathrm{CO}_{2}\right)$ and increased DO concentration. The facility produced approximately $36,000 \mathrm{~kg}$ rainbow trout annually. The primary market for this facility was human consumption, with restaurants being the main purchaser.

Water from a deep mine drain flowed by gravity to a packed column to remove $\mathrm{CO}_{2}$ and increase the DO (see Figure 3.1.11). Water was then distributed through parallel delivery piping to $2-10.0 \mathrm{~m}^{3}, 5-37.9 \mathrm{~m}^{3}$, and $4-75.8 \mathrm{~m}^{3}$ circular tanks. A photograph of the circular tanks is presented in Figure 3.1.14. Liquid oxygen was fed to the influent of each tank to increase DO concentrations. Water from the tanks was then discharged to a drainage ditch to transfer the effluent to the receiving water body. Stand pipes in each tank in the system drained to an offline sedimentation (OLS) pond, in which solids settled and the supernate discharged to the 
vegetated ditch and then into the receiving water body. The facility did not have an NPDES Permit.

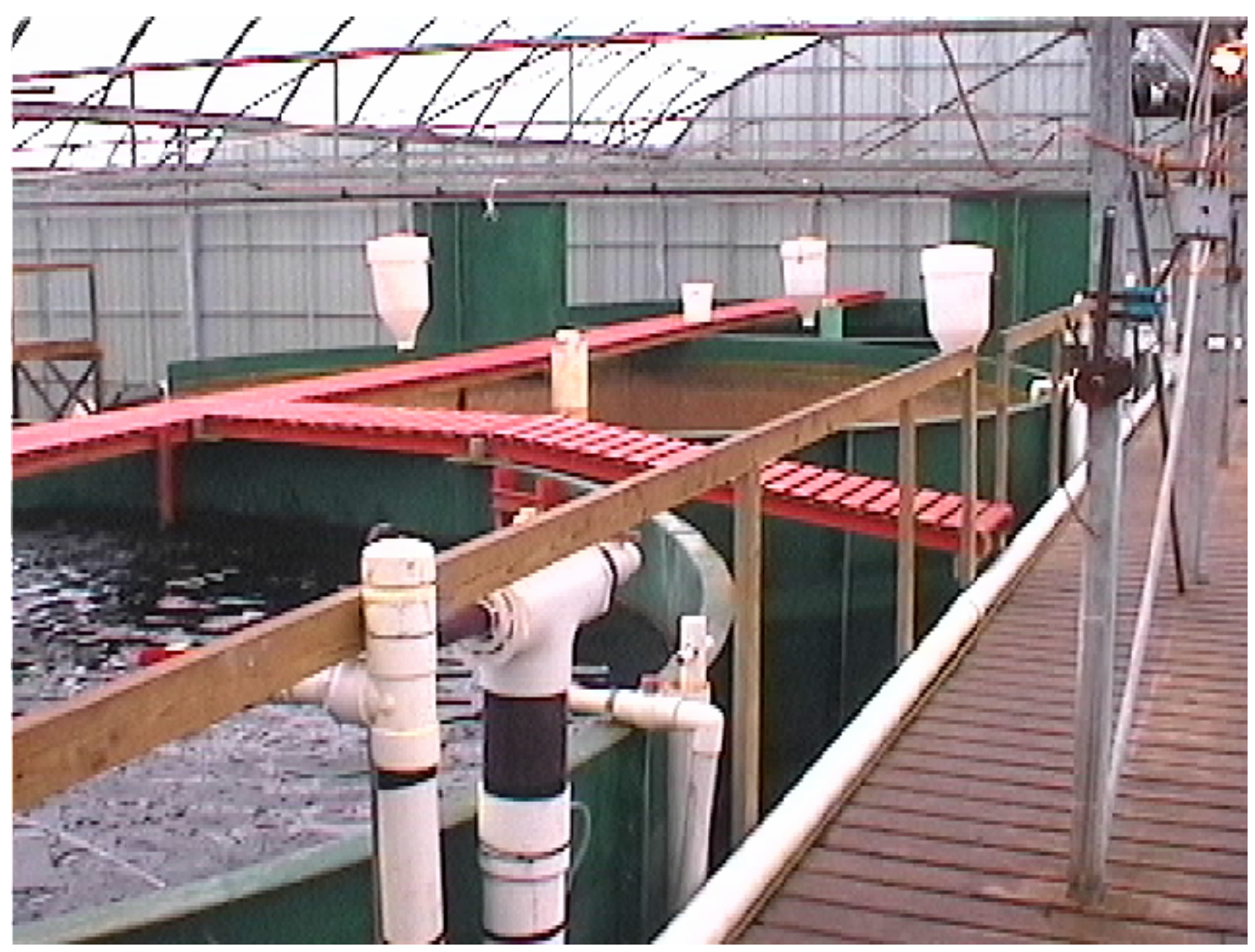

Figure 3.1.14 Photograph of the Circular Tanks at Facility F.

\subsubsection{Sampling Sites}

In order to perform a "cause and effect" comparison of production, influent and effluent were monitored to ascertain the net effects of the hatchery on water quality. Facility E had an additional effluent site from the OLS pond that was also monitored in conjunction with the effluent from the primary system.

\subsubsection{Sampling Regime}


Each facility was visited approximately every six weeks for one year and then approximately once per quarter for an additional year. Each site visit included field monitoring and the collection of grab samples for analysis.

\subsubsection{Field Monitoring and Grab Samples}

Field monitoring consisted of measuring flow, water temperature, $\mathrm{pH}, \mathrm{DO}$, specific conductance, and turbidity. Grab sampling was conducted during each site visit and samples were collected for $\mathrm{BOD}_{5}$, TSS, SS, TAN, $\mathrm{NO}_{2}{ }^{-}$, and $\mathrm{NO}_{3}{ }^{-}$analysis.

\subsection{Methods}

\subsubsection{Field Monitoring}

Instruments used for field monitoring are presented in Table 3.2.1.1. Measurements were taken using YSI portable meters, a Hach turbidimeter, and a Marsh-McBirney Inc. FLO-MATE flow meter.

Table 3.2.1.1 Instruments Employed in Field Monitoring.

\begin{tabular}{cccc}
\hline Parameter(s) Measured & Manufacturer & Model & Type of Instrument \\
\hline pH/Conductivity/Temp. & YSI & 63 & Electrode \\
DO, \% Saturation, Temp. & YSI & 95 & Electrode \\
Turbidity & Hach & $2100 \mathrm{P}$ & Spectrophotometer \\
Flowrate & Marsh-McBirney & 2000 & Electromagnetic \\
\hline
\end{tabular}

The YSI $63 \mathrm{pH}$ meter was calibrated prior to each use. Following the manufacturer's instructions, a two point calibration was performed using $\mathrm{pH} 7$ and $\mathrm{pH} 10$ buffers. The YSI 95 DO meter was calibrated with each use per manufacturer's instructions employing percent saturation according to elevation in one-hundred foot increments. The Hach turbidimeter was checked for accuracy each use with standards of 5.57 NTU, 56.1 NTU, and 550 NTU. When the calibration procedures were completed and documented, field measurements of influent and effluent waters were made. 
Sites and methods for flow measurements were taken at each site based on an assessment of facility layout and design. Determination using one of three approaches are detailed below.

Water height over outlet weirs was measured and flowrate was determined using a rectangular streamlined weir equation (EQN. 3.1) (Lin, 2001)

$$
\begin{aligned}
& Q=1.705 L H^{3 / 2} \\
& \text { where } \quad \begin{array}{l}
Q=\text { flow rate, } \mathrm{m}^{3} / \mathrm{s} \\
L=\text { weir length, } \mathrm{m} \\
H=\text { head on weir, } \mathrm{m}
\end{array}
\end{aligned}
$$

Stream velocity and cross-sectional were also measured and placed into a open-channel flow equation (EQN. 3.2) (Lin, 2001).

$$
Q=V A
$$

$$
\text { where } \quad \begin{aligned}
Q & =\text { flow rate, } \mathrm{m}^{3} / \mathrm{s} \\
V & =\text { average velocity, } \mathrm{m} / \mathrm{s} \\
A & =\text { cross-sectional area, } \mathrm{m}
\end{aligned}
$$

The timed volumetric method was also used to determine flowrate, and is presented in equation (EQN. 3.3).

$$
Q=V o l . / t
$$

where

$$
\begin{aligned}
& Q=\text { flow rate, } \mathrm{m}^{3} / \mathrm{s} \\
& \text { Vol. }=\text { know volume, } \mathrm{m} \\
& t=\text { time, } \mathrm{s}
\end{aligned}
$$

Presented in Table 3.2.1.2 are the site locations and methods for flow measurement at each facility. 
Table 3.2.1.2 Location and Methods of Flow Determination at Study Sites

\begin{tabular}{ccc}
\hline Facility & Location & Method \\
\hline A & Influent Pipe & Eq. 3.3 \\
B & Effluent Structure & Eq. 3.1 \\
C & End of Raceways & Eq. 3.1 \\
$D$ & Earthen Raceways & Eq. 3.2 \\
E & Influent Pipes & Eq. 3.3 \\
F & Discharge Ditch & Eq. 2 \\
\hline
\end{tabular}

\subsubsection{Grab Sample Analysis}

\subsubsection{Nutrients}

Samples were collected in high density polyethylene (HDPE) bottles with zero headspace, $\mathrm{pH}$ adjusted to $<2$ standard units with $\mathrm{H}_{2} \mathrm{SO}_{4}$, and stored at $4^{\circ} \mathrm{C}$ until analysis. Nutrients were analyzed by the National Research Center for Coal and Energy (NRCCE), a WVDEP certified laboratory. Analytical methods used in assays performed by the NRCCE are presented in Table 3.2.2.1.

Table 3.2.2.1 Analytical Methods Used in Assays Performed by the NRCCE.

\begin{tabular}{cc}
\hline Assay & EPA Method \\
\hline Nitrite, $\mathrm{NO}^{2-}$ & 353.2 \\
Nitrate, $\mathrm{NO}^{3-}$ & 353.2 \\
Total Ammonia Nitrogen, (TAN) & 350.1 \\
Total Phosphorus, (TP) & 200.7 \\
\hline
\end{tabular}

\subsubsection{Biochemical Oxygen Demand}

Samples were collected in HDPE bottles with zero headspace and stored at $4^{\circ} \mathrm{C}$ until analysis (hold time 48 hours). Researchers at the West Virginia University Department of Civil and Environmental Engineering (WVU-CEE) conducted $\mathrm{BOD}_{5}$ measurements following EPA method number 405.1 .

\subsubsection{Solids}


Samples were collected in HDPE bottles with zero headspace and stored at $4^{\circ} \mathrm{C}$ until analysis (hold time 7 days). WVU-CEE researchers conducted non-filterable solids (TSS) measurements following EPA method number 160.2.

\subsection{Quality Assurance and Quality Control}

\subsubsection{External Laboratory Analyses}

A field triplicate (one sample split into three) was taken during each sampling excursion. Each individual analyte was measured in each of the triplicate samples by the external laboratory. Triplicate sample analyses were used to assess the analytical precision of the laboratory. Suspected “outliers" were subjected to the Dixon's Extreme Value test for statistical analysis before their removal (US EPA, 1998).

\subsubsection{In-house Laboratory Analyses}

\subsubsection{Solids}

A triplicate sample was taken and analyzed during each sampling excursion to measure the precision of the analytical procedure. For TSS, sample blanks and replicates were analyzed on at least $10 \%$ of all samples in the batch.

\subsubsection{Biochemical Oxygen Demand}

Quality analysis/quality control procedures of $\mathrm{BOD}_{5}$ included field triplicates, seed controls, dilution water blanks, and glucose-glutamic acid checks.

To ensure populations of microorganisms were present and capable of oxidizing biodegradable or organic matter in the sample, the sample was seeded with Polyseed ${ }^{\mathrm{TM}}$. Dilution water blanks check the quality of dilution water and can detect the development of nitrifying bacteria in the dilution water. Glucose-glutamic acid checks serve as a "standard" check and measure the accuracy of the procedure. 


\subsubsection{Field Meters}

YSI field meters were calibrated per manufacturer's instructions at the beginning of each sampling visit as outlined previously in Section 3.5.1. In addition, the DO and conductivity / $\mathrm{pH}$ probes were cleaned, calibrated, and the DO membrane cap replaced when needed. Accuracy of the Hach turbidimeter was verified at the start of each sampling event using gelex ${ }^{\mathrm{TM}}$ standards and calibrated in the laboratory using stablcal formazin ${ }^{\mathrm{TM}}$ standards per manufacturer's instructions.

\subsection{Statistical Analyses}

\subsubsection{Paired t-Test}

The paired $t$-test is a parametric statistical method that assumes the observed treatment effects are normally distributed and used when you want to determine if a treatment on one individual is significant (SPSS, 1997). For this research, a comparison of facility influent and effluent were compared to determine if the water quality had significantly changed through the process.

Examining the changes rather than the values observed before and after the intervention removes the differences due to individual responses, producing a more sensitive, or powerful, test (Hayter, 1996). The paired $t$-test is a parametric statistical method, and thus is only used when the observed treatment effects are consistent with a normally distributed population (data set), and the populations have equal variance (SPSS, 1997). In a normally distributed data set $67 \%$ of all data falls within two standard deviations of the mean, if the positive deviation is equal to the negative deviation, then the data set has equal variance. Sigma Stat software, a program by SPSS (1997), was used to determine the $t$-test statistic using a 95 percent level of confidence, $\alpha=$ 0.05 , and $P=0.05$. 
The value of the $t$-test statistic is indicative of whether or not a statistically significant difference exists between the two sets of data used for the paired $t$-test and was computed using equation 3.7.1.1.

$$
t=\frac{\text { mean difference of the data sets }}{\text { standard error of the mean difference }}
$$

Statistically significant differences existed when the absolute value of the paired $t$-test statistic was large $(|t| \geq 2)$, which meant that the difference in the two data sets was larger than what could be otherwise attributed to random variability, alone. For absolute values of the $t$-test statistic close to zero, one assumes there is no significant difference between the two data sets (SPSS, 1997). The Sigma Stat software was programmed to recognize an absolute value of two as the boundary for statistically significant differences, that is, for $t$-test statistic values greater than $|2|$, one could conclude there existed a statistically significant difference. Likewise, for $t$ test statistic values less than $|2|$, one could conclude no statistically significant difference existed.

Confidence intervals were calculated using the paired $t$-test data. If the confidence interval included zero, one could conclude a statistically significant difference did not exist (Hogg and Ledolter, 1992, SPSS, 1997). The level of confidence, reported as a percentage, is the level to which one could assume the data fell within the confidence interval. In this instance, one could be $95 \%$ confident that the difference of the population means fell within the confidence interval for each specific test run (Hogg and Ledolter, 1992).

Alpha was the acceptable probability of incorrectly concluding that there was a statistically significant difference between the influent and effluent (SPSS, 1997). Using $\alpha=$ 0.05 , a chance of error equal to $5 \%$ was acceptable. Larger values of $\alpha$ expanded the requirements of concluding there was a significant difference, but also increased the risk of incorrectly concluding there was a statistically significant difference. 
Finally, the $P$ value was the probability of wrongly concluding that there was a significant effect (SPSS, 1997). For values of $P<0.05$, one can assume that a statistically significant difference did exist.

\subsubsection{Wilcoxon Signed Rank Test.}

When analyzed data is nonparametric, the Wilcoxon Signed Rank Test was used to assess the effect of facility production on process waters from influent to effluent. This test analyzes the paired differences of the influent and effluent data. Under the null hypothesis of no differences between influent and effluent data, you would expect half of the differences between pairs to be negative and half positive, that is the average being $n / 2$ [where $n$ is the number of pairs] (Hogg and Ledolter, 1992). The observed treatment differences are ranked without regard to sign and then signs are added to each pair. The ranks are then summed and compared. If the ranks tend to have the same sign, there is a statistically significant difference between the influent and effluent data (SPSS, 1997).

\section{CHAPTER 4. RESULTS}

\subsection{Facility A}

\subsubsection{Field Monitoring}

Field monitoring results for Facility A from January 2001 to October 2002 are presented in Table 4.1.1.1. Averages and ranges of concentrations are presented to show extremes due to seasonal variations and impacts of production activities, however the exact cause of those extremes was not thoroughly investigated. 
Table 4.1.1.1. Field Monitoring Results of Facility A.

\begin{tabular}{cccccc}
\hline Site & $\begin{array}{c}\mathbf{p H}, \text { Std. Units } \\
\text { average } \\
\text { [range] }\end{array}$ & $\begin{array}{c}\text { Temperature, }{ }^{\circ} \mathbf{C} \\
\text { average } \\
\text { [range] }\end{array}$ & $\begin{array}{c}\text { Spc. Cond., } \mu \mathbf{S} / \mathbf{c m} \\
\text { average } \\
\text { [range] }\end{array}$ & $\begin{array}{c}\text { DO, } \mathbf{~ m g / L} \\
\text { average } \\
\text { [range] }\end{array}$ & $\begin{array}{c}\text { Turbidity, NTU } \\
\text { average } \\
\text { [range] }\end{array}$ \\
\hline \multirow{2}{*}{ Influent } & 7.17 & 10.76 & 185.8 & 9.16 & 1.61 \\
& {$[6.57-7.57]$} & {$[7.3-12.8]$} & {$[148.7-233.6]$} & {$[8.27-11.1]$} & {$[0.54-4.81]$} \\
Effluent & 7.08 & 11.62 & 195.1 & 7.25 & 4.21 \\
& {$[6.71-7.49]$} & {$[5.8-16.3]$} & {$[144.1-245.4]$} & {$[5.92-9.55]$} & {$[1.88-8.91]$} \\
\hline
\end{tabular}

\subsubsection{Flow}

Facility A had a built-in electronic flow meter; however, it was not in working condition during the entire study. The average flow recorded was $7,142 \mathrm{~m}^{3} / \mathrm{sec}$. (1,310 GPM) and was consistent with the NPDES permitted amount of 7,631 $\mathrm{m}^{3} / \mathrm{sec}$. [1,400 GPM] (WVDEP, 1993). Fluctuations were seasonally influenced by the production of the adjacent groundwater spring.

\subsubsection{2 pH}

Measured $\mathrm{pH}$ values are summarized in Table 4.1.1.1 and presented fully in Table A.1. Influent $\mathrm{pH}$ values ranged from 6.57 to 7.57 standard units and averaged 7.17. Effluent $\mathrm{pH}$ values ranged from 6.71 to 7.49 and averaged 7.08. All measured values were within the permitted range between 6 - 9 standard units (WVDEP, 1993).

\subsubsection{Specific Conductance}

Specific conductance values summarized in Table 4.1.1.1 are presented fully in Table A.2. Influent specific conductance values ranged from 148.7 to $233.6 \mu \mathrm{S} / \mathrm{cm}$ and averaged $185.8 \mu \mathrm{S} / \mathrm{cm}$. Effluent specific conductance values ranged from 144.1 to $245.4 \mu \mathrm{S} / \mathrm{cm}$ and averaged $195.1 \mu \mathrm{S} / \mathrm{cm}$.

\subsubsection{Temperature}

Temperature, summarized in Table 4.1.1.1 and presented fully in Table A.1, ranged from 7.3 to $12.8{ }^{\circ} \mathrm{C}$ (45 to $55^{\circ} \mathrm{F}$ ) with an average of $10.8{ }^{\circ} \mathrm{C}\left(51{ }^{\circ} \mathrm{F}\right)$ in the influent and effluent 
temperatures ranged from 5.8 to $16.3{ }^{\circ} \mathrm{C}\left(42\right.$ to $\left.61{ }^{\circ} \mathrm{F}\right)$ with an average of $11.6{ }^{\circ} \mathrm{C}\left(53{ }^{\circ} \mathrm{F}\right)$. Monitored temperatures were in acceptable ranges for the survival of rainbow trout (Meade, 1989). Temperature was not a regulated parameter in the facility's NPDES Permit.

\subsubsection{Dissolved Oxygen}

Dissolved oxygen concentrations summarized in Table 4.1.1.1, are presented fully in Table A.2. Typically, DO concentrations remained relatively constant in the facility's influent, ranging from 8.27 to $11.06 \mathrm{mg} / \mathrm{L}$, averaged $9.16 \mathrm{mg} / \mathrm{L}$, and were within the acceptable range for salmonid production (5 mg/L to saturation; Heinen 1996). Effluent DO concentrations ranged from 5.92 to $9.55 \mathrm{mg} / \mathrm{L}$ and average $7.25 \mathrm{mg} / \mathrm{L}$. The facility operated floating-surface aerators in the sedimentation pond to increase DO concentrations above the lower NPDES regulated limit of $6 \mathrm{mg} / \mathrm{L}$, however one measurement failed to meet this limitation (WVDEP, 1993).

\subsubsection{Turbidity}

Turbidity values are summarized in Table 4.1.1.1 and presented fully in Table A.2. Influent turbidity ranged from 0.54 to $4.81 \mathrm{NTU}$ and averaged 1.61 NTU. Effluent turbidity ranged from 1.88 to $8.91 \mathrm{NTU}$ and averaged 4.21 NTU.

\subsubsection{Grab Samples}

Grab sample results from January 2001 to October 2002 are summarized in Table 4.1.2.1 and presented fully in Table A.3. Averages and ranges of concentration and loading are presented to show extremes due to seasonal variations and impacts of production activities. 
Table 4.1.2.1 Grab Sample Results of Facility A.

\begin{tabular}{|c|c|c|c|c|c|}
\hline Site & $\begin{array}{c}\text { TSS } \\
\text { average } \\
\text { [range] }\end{array}$ & $\begin{array}{c}\mathbf{B O D}_{5} \\
\text { average } \\
\text { [range] }\end{array}$ & $\begin{array}{c}\mathrm{NH}_{3} \\
\text { average } \\
\text { [range] }\end{array}$ & $\begin{array}{c}\mathrm{NO}_{3}^{-} \\
\text {average } \\
\text { [range] }\end{array}$ & $\begin{array}{c}\text { TP } \\
\text { average } \\
\text { [range] }\end{array}$ \\
\hline $\begin{array}{l}\text { Influent } \\
\text { concentration, } \\
\mathrm{mg} / \mathrm{L}\end{array}$ & $\begin{array}{c}5.8 \\
{[1.0-32.0]}\end{array}$ & $\begin{array}{c}1.43^{\dagger} \\
{[1.43]}\end{array}$ & $\begin{array}{c}0.07^{\dagger} \\
{\left[0.005^{\dagger}-0.15\right]}\end{array}$ & $\begin{array}{c}0.76 \\
{[0.46-1.53]}\end{array}$ & $\begin{array}{c}0.009^{\dagger} \\
{\left[0.005^{\dagger}-0.04\right]}\end{array}$ \\
\hline $\begin{array}{l}\text { Effluent } \\
\text { concentration, } \\
\mathrm{mg} / \mathrm{L}\end{array}$ & $\begin{array}{c}11.5 \\
{[4.5-17.5]}\end{array}$ & $\begin{array}{c}4.70^{\dagger} \\
{\left[1.43^{\dagger}-11.96\right]}\end{array}$ & $\begin{array}{c}0.31 \\
{[0.14-0.53]}\end{array}$ & $\begin{array}{c}1.28 \\
{[0.85-1.92]}\end{array}$ & $\begin{array}{c}0.50 \\
{[0.22-1.24]}\end{array}$ \\
\hline $\begin{array}{l}\text { Effluent loading, } \\
\mathrm{kg} / \mathrm{d}\end{array}$ & $\begin{array}{c}78.1 \\
{[18.5-148.4]}\end{array}$ & $\begin{array}{c}34.5^{\dagger} \\
{\left[10.5^{\dagger}-101.4\right]}\end{array}$ & $\begin{array}{c}2.02 \\
{[0.06-5.34]}\end{array}$ & $\begin{array}{c}8.60 \\
{[6.52-11.04]}\end{array}$ & $\begin{array}{c}3.58 \\
{[1.20-10.52]}\end{array}$ \\
\hline
\end{tabular}

\subsubsection{Total Suspended Solids (TSS)}

Concentration and mass loading of effluent TSS were below the acceptable limit of the facility's NPDES permit (30 mg/L average monthly and $60 \mathrm{mg} / \mathrm{L}$ maximum daily). TSS concentrations are summarized in Table 4.1.2.1 and presented in full in Tables A.3 to A.6. Influent TSS concentrations ranged from $1.0 \mathrm{mg} / \mathrm{L}$ to $32 \mathrm{mg} / \mathrm{L}$ and averaged $5.78 \mathrm{mg} / \mathrm{L}$. Effluent TSS concentrations ranged from $4.50 \mathrm{mg} / \mathrm{L}$ to $17.5 \mathrm{mg} / \mathrm{L}$ and averaged $11.5 \mathrm{mg} / \mathrm{L}$. TSS loadings ranged from 18.49 to $148.41 \mathrm{~kg} / \mathrm{d}$ and averaged $78.12 \mathrm{~kg} /$ day.

\subsubsection{Five Day Biochemical Oxygen Demand $\left(B O D_{5}\right)$}

Concentration and mass loading of effluent $\mathrm{BOD}_{5}$ were below the NPDES permitted limit (30 mg/L average monthly and $60 \mathrm{mg} / \mathrm{L}$ maximum daily). All influent grab samples taken and analyzed for $\mathrm{BOD}_{5}$ were below the MDL of $2.86 \mathrm{mg} / \mathrm{L}$. Effluent concentrations of $\mathrm{BOD}_{5}$ ranged from 1.43 to $11.96 \mathrm{mg} / \mathrm{L}$ and averaged $4.70 \mathrm{mg} / \mathrm{L}$. Effluent mass loadings of $\mathrm{BOD}_{5}$ ranged from 10.5 to $101.4 \mathrm{~kg} / \mathrm{d}$ and averaged $34.5 \mathrm{~kg} / \mathrm{d}$. Results are summarized in Table 4.1.2.1 and presented fully in Table A.6. 


\subsubsection{Total Ammonia Nitrogen (TAN)}

Total ammonia nitrogen concentrations and mass loadings are summarized in Table 4.1.2.1 and presented fully in Table A.4. Influent TAN concentrations ranged from 0.005 to 0.15 $\mathrm{mg} / \mathrm{L}$ and averaged $0.07 \mathrm{mg} / \mathrm{L}$. Effluent $\mathrm{NH}_{3}$ concentrations ranged from 0.14 to $0.53 \mathrm{mg} / \mathrm{L}$ and averaged $0.31 \mathrm{mg} / \mathrm{L}$. Effluent mass loadings ranged between 0.06 to $5.34 \mathrm{~kg} / \mathrm{d}$ and averaged $2.02 \mathrm{~kg} / \mathrm{d}$. Concentration and mass loading of effluent $\mathrm{NH}_{3}$ were below the allowable limit of the facility's NPDES permit (10.44 $\mathrm{mg} / \mathrm{L}$ maximum daily).

\subsubsection{Nitrate $\left(\mathrm{NO}_{3}^{-}\right)$}

Nitrate concentrations and mass loadings are summarized in Table 4.1.2.1 and presented fully in Tables A.4 and A.5. Nitrate is not regulated under the facility's existing NPDES permit. Influent nitrate concentrations ranged from 0.46 to $1.53 \mathrm{mg} / \mathrm{L}$ and averaged $0.76 \mathrm{mg} / \mathrm{L}$. Effluent nitrate concentrations ranged from 0.85 to $1.92 \mathrm{mg} / \mathrm{L}$ and averaged $1.28 \mathrm{mg} / \mathrm{L}$. Effluent mass loadings ranged between 6.52 to $11.04 \mathrm{~kg} / \mathrm{d}$ and averaged $8.60 \mathrm{~kg} / \mathrm{d}$.

\subsubsection{Total Phosphorus (TP)}

Total phosphorus concentrations and mass loadings are summarized in Table 4.1.2.1 and presented fully in Tables A.5 and A.6. Influent total phosphorus concentrations ranged from 0.001 to $0.04 \mathrm{mg} / \mathrm{L}$ and averaged $0.009 \mathrm{mg} / \mathrm{L}$. Effluent total phosphorus concentrations ranged from 0.22 to $1.24 \mathrm{mg} / \mathrm{L}$ and averaged $0.50 \mathrm{mg} / \mathrm{L}$. Effluent mass loadings ranged between 1.20 to $10.52 \mathrm{~kg} / \mathrm{d}$ and averaged $3.58 \mathrm{~kg} / \mathrm{d}$. Total phosphorus is not regulated under the facility's existing NPDES permit.

\subsubsection{Nitrite $\left(\mathrm{NO}_{2}^{-}\right)$}

All influent grab samples had nitrite concentrations less than the MDL of $0.01 \mathrm{mg} / \mathrm{L}$. All but two of the effluent grab samples had nitrite concentrations less than the MDL; with those 
concentrations being 0.023 and $0.024 \mathrm{mg} / \mathrm{L}$. The resulting mass loadings were 0.13 and 0.10 $\mathrm{kg} / \mathrm{d}$. These results are presented fully in Table A.5.

\subsubsection{Statistical Analysis}

The Paired $t$-Test and Wilcoxon Signed Rank Test were used to determine if any significance difference existed between influent and effluent monitored parameters. The Paired $t$-Test was used when observed treatment effects were normally distributed, while the Wilcoxon Signed Rank Test was employed with non-normal distribution. The Summaries of the statistical analysis results are presented in Table 4.1.3.1.

Table 4.1.3.1 Facility A Water Quality Monitoring Statistical Analysis Results.

\begin{tabular}{lcccc}
\hline \multicolumn{1}{c}{ Parameter } & $\begin{array}{c}\text { Normality Test } \\
\text { Passed? (Y/N) }\end{array}$ & Test Used & P & $\begin{array}{c}\text { Statistically } \\
\text { Significant } \\
\text { Difference? (Y/N; } \\
\mathbf{P}<\mathbf{0 . 0 5})\end{array}$ \\
\hline $\mathrm{pH}$ & $\mathrm{Y}$ & Paired t-test & 0.262 & $\mathrm{~N}$ \\
Temperature & $\mathrm{Y}$ & Paired t-test & 0.135 & $\mathrm{~N}$ \\
Dissolved Oxygen & $\mathrm{Y}$ & Paired t-test & 0.005 & $\mathrm{Y}$ \\
Spc. Cond. & $\mathrm{Y}$ & Paired t-test & 0.007 & $\mathrm{Y}$ \\
Turbidity & $\mathrm{Y}$ & Paired t-test & 0.009 & $\mathrm{Y}$ \\
TSS & $\mathrm{Y}$ & Paired t-test & $<0.001$ & $\mathrm{Y}$ \\
Ammonia & $\mathrm{Y}$ & Paired t-test & $<0.001$ & $\mathrm{Y}$ \\
Nitrate & $\mathrm{Y}$ & Paired t-test & 0.020 & $\mathrm{Y}$ \\
Total P & $\mathrm{Y}$ & Paired t-test & 0.002 & $\mathrm{Y}$ \\
BOD $_{5}$ & $\mathrm{Y}$ & Paired t-test & 0.011 & $\mathrm{Y}$ \\
Nitrite & $\mathrm{N}$ & Wilcoxon Signed & 0.500 & $\mathrm{~N}$ \\
\hline
\end{tabular}

\subsection{Facility B}

\subsubsection{Field Monitoring}

Field monitoring results for Facility B from November 2000 to October 2002 are presented in Table 4.2.1.1. Averages and ranges of concentrations are presented to show extremes due to seasonal variations and impacts of production activities. 
Table 4.2.1.1. Field Monitoring Results of Facility B.

\begin{tabular}{cccccc}
\hline Site & $\begin{array}{c}\mathbf{p H}, \text { Std. Units } \\
\text { average } \\
\text { [range] }\end{array}$ & $\begin{array}{c}\text { Temperature, }{ }^{\circ} \mathbf{C} \\
\text { average } \\
\text { [range] }\end{array}$ & $\begin{array}{c}\text { Spc. Cond., } \mu \mathbf{S} / \mathbf{c m} \\
\text { average } \\
\text { [range] }\end{array}$ & $\begin{array}{c}\text { DO, } \mathbf{~ m g / L} \\
\text { average } \\
\text { [range] }\end{array}$ & $\begin{array}{c}\text { Turbidity, NTU } \\
\text { average } \\
\text { [range] }\end{array}$ \\
\hline \multirow{2}{*}{ Influent } & 7.41 & 11.81 & 307.6 & 9.33 & 1.67 \\
& {$[6.88-7.92]$} & {$[9.30-13.40]$} & {$[166.5-360.0]$} & {$[8.28-10.1]$} & {$[0.54-5.92]$} \\
Effluent & 7.48 & 13.81 & & & \\
& {$[7.04-8.08]$} & {$[10.90-19.70]$} & {$[313.7-357.1]$} & {$[7.80-12.7]$} & {$[0.39-1.80]$} \\
\hline
\end{tabular}

\subsubsection{Flow}

Measured flow rates, presented fully in Table B.1, ranged from 1,139 to $8,399 \mathrm{~m}^{3} /$ day and averaged 4,166 $\mathrm{m}^{3} /$ day $(209,1541$, and $764 \mathrm{GPM})$.

\subsubsection{2 $\mathrm{pH}$}

Measured pH values are summarized in Table 4.2.1.1 and presented fully in Table B.1. Influent $\mathrm{pH}$ values ranged from 6.88 to 7.92 standard units and averaged 7.41. Effluent $\mathrm{pH}$ values ranged from 7.04 to 8.08 and averaged 7.48 .

\subsubsection{Specific Conductance}

Specific conductance values summarized in Table 4.2.1.1 are presented fully in Table B.2. Influent specific conductance values ranged from 166.5 to $360.0 \mu \mathrm{S} / \mathrm{cm}$ and averaged $307.6 \mu \mathrm{S} / \mathrm{cm}$. Effluent specific conductance values ranged from 313.7 to $357.1 \mu \mathrm{S} / \mathrm{cm}$ and averaged $328.9 \mu \mathrm{S} / \mathrm{cm}$.

\subsubsection{Temperature}

Temperature values, summarized in Table 4.2.1.1, are presented fully in Table B.1. Influent temperatures ranged from 9.30 to $13.4{ }^{\circ} \mathrm{C}\left(48.7\right.$ to $\left.56.1{ }^{\circ} \mathrm{F}\right)$ and averaged $11.81{ }^{\circ} \mathrm{C}(53.3$ $\left.{ }^{\circ} \mathrm{F}\right)$. Effluent temperatures ranged from 10.9 to $19.7^{\circ} \mathrm{C}\left(51.6\right.$ to $\left.53.5^{\circ} \mathrm{F}\right)$ and averaged $13.8^{\circ} \mathrm{C}$ $\left(56.9^{\circ} \mathrm{F}\right)$. Monitored temperatures were within acceptable ranges for the survival of rainbow trout (Meade, 1989). 


\subsubsection{Dissolved Oxygen}

Dissolved oxygen concentrations summarized in Table 4.2.1.1, are presented fully in Table B.2. Typically, DO concentrations remained relatively constant in the facility's influent, ranging from 8.28 to $10.06 \mathrm{mg} / \mathrm{L}$, with an average of $9.33 \mathrm{mg} / \mathrm{L}$, and were within the acceptable range for salmonid production (5 mg/L to saturation; Heinen 1996). Effluent DO concentrations ranged from 7.80 to $12.67 \mathrm{mg} / \mathrm{L}$ and average $10.23 \mathrm{mg} / \mathrm{L}$.

\subsubsection{Turbidity}

Turbidity values are summarized in Table 4.2.1.1 and presented fully in Table B.2. Influent turbidity ranged from 0.54 to $5.92 \mathrm{NTU}$ and averaged 1.67 NTU. Effluent turbidity ranged from 0.39 to $6.41 \mathrm{NTU}$ and averaged $1.80 \mathrm{NTU}$.

\subsubsection{Grab Samples}

Grab sample results from November 2000 to October 2002 are summarized in Table 4.2.2.1 and presented fully in Table B.3 to B.6. Averages and ranges of concentration and loading are presented to show extremes due to seasonal variations and impacts of production activities. 
Table 4.2.2.1 Grab Sample Results of Facility B.

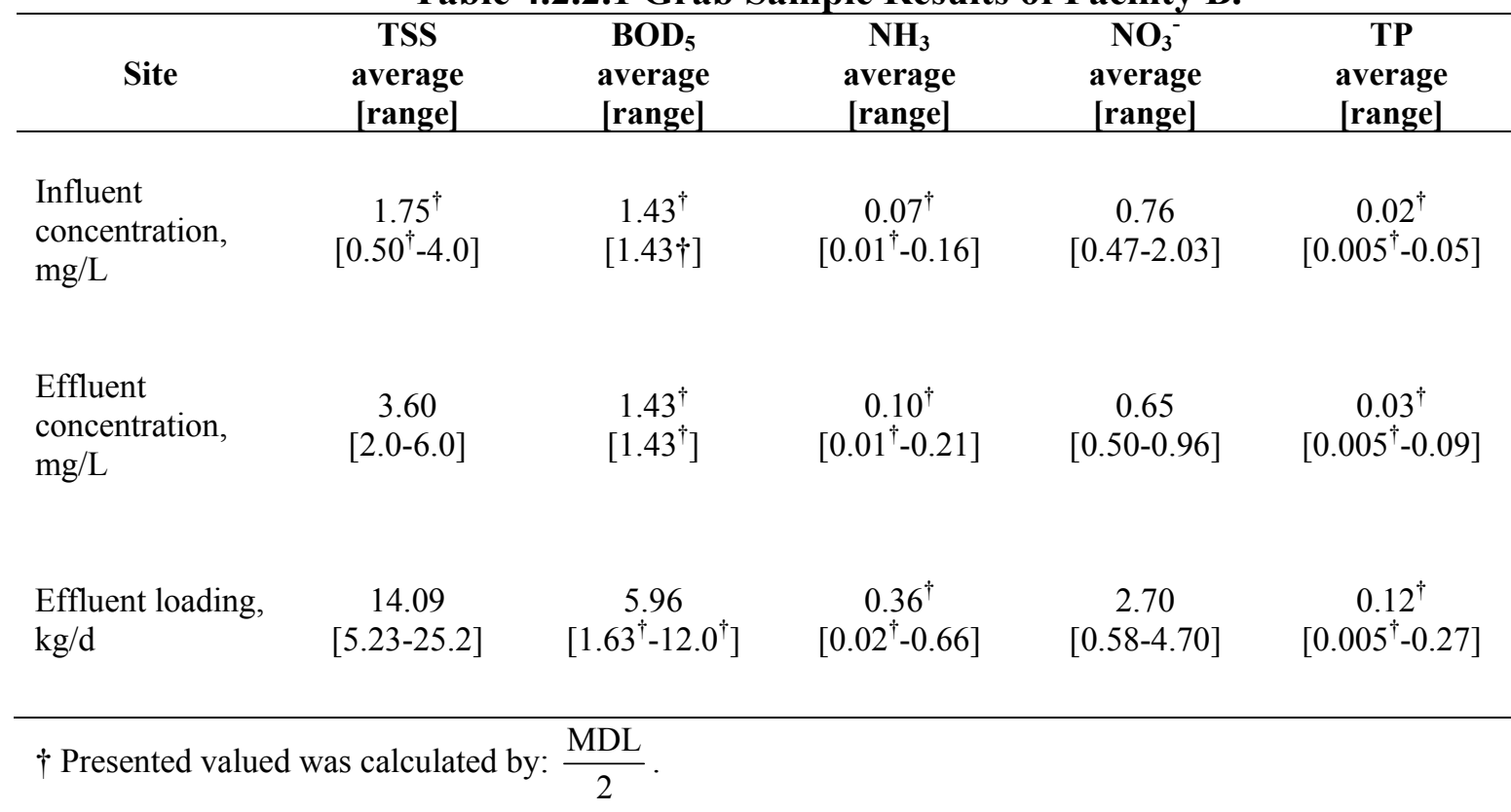

\subsubsection{Total Suspended Solids (TSS)}

TSS concentrations are summarized in Table 4.2.2.1 and presented fully in Table B.3. Influent TSS concentrations ranged from 0.50 to $4.0 \mathrm{mg} / \mathrm{L}$ and averaged $1.75 \mathrm{mg} / \mathrm{L}$. Effluent TSS concentrations ranged from 2.0 to $6.0 \mathrm{mg} / \mathrm{L}$ and averaged $3.60 \mathrm{mg} / \mathrm{L}$. TSS loadings ranged from 5.23 to $25.20 \mathrm{~kg} / \mathrm{d}$ and averaged $14.09 \mathrm{~kg} /$ day.

\subsubsection{Five Day Biochemical Oxygen Demand $\left(B O D_{5}\right)$}

All influent and effluent grab samples taken and analyzed for $\mathrm{BOD}_{5}$ were below the MDL. Effluent mass loadings of $\mathrm{BOD}_{5}$ ranged from 1.63 to $12.0 \mathrm{~kg} / \mathrm{d}$ and averaged $5.96 \mathrm{~kg} / \mathrm{d}$. Results are summarized in Table 4.2.2.1 and presented fully in Table B.6.

\subsubsection{Total Ammonia Nitrogen (TAN)}

Ammonia concentrations and mass loadings are summarized in Table 4.2.2.1 and presented fully in Tables B.3 and B.4. Influent $\mathrm{NH}_{3}$ concentrations ranged from 0.01 to 0.16 $\mathrm{mg} / \mathrm{L}$ and averaged $0.07 \mathrm{mg} / \mathrm{L}$. Effluent $\mathrm{NH}_{3}$ concentrations ranged from 0.01 to $0.21 \mathrm{mg} / \mathrm{L}$ and 
averaged $0.10 \mathrm{mg} / \mathrm{L}$. Effluent mass loadings ranged from 0.02 to $0.66 \mathrm{~kg} / \mathrm{d}$ and averaged 0.36 $\mathrm{kg} / \mathrm{d}$.

\subsubsection{Nitrate $\left(\mathrm{NO}_{3}{ }^{-}\right)$}

Nitrate concentrations and mass loadings are summarized in Table 4.2.2.1 and presented fully in Tables B.4 and B.5. Influent nitrate concentrations ranged from 0.47 to $2.03 \mathrm{mg} / \mathrm{L}$ and averaged $0.76 \mathrm{mg} / \mathrm{L}$. Effluent nitrate concentrations ranged from 0.50 to $0.96 \mathrm{mg} / \mathrm{L}$ and averaged $0.65 \mathrm{mg} / \mathrm{L}$. Effluent mass loadings ranged from 0.58 to $4.70 \mathrm{~kg} / \mathrm{d}$ and averaged 2.70 $\mathrm{kg} / \mathrm{d}$.

\subsubsection{Total Phosphorus (TP)}

Total phosphorus concentrations and mass loadings are summarized in Table 4.2.2.1 and presented fully in Table B.6. Influent total phosphorus concentrations ranged from 0.005 to 0.05 $\mathrm{mg} / \mathrm{L}$ and averaged $0.02 \mathrm{mg} / \mathrm{L}$. Effluent total phosphorus concentrations ranged from 0.005 to $0.09 \mathrm{mg} / \mathrm{L}$ and averaged $0.03 \mathrm{mg} / \mathrm{L}$. Effluent mass loadings ranged from 0.001 to $0.27 \mathrm{~kg} / \mathrm{d}$ and averaged $0.12 \mathrm{~kg} / \mathrm{d}$.

\subsubsection{Nitrite $\left(\mathrm{NO}_{2}\right)$}

All influent and effluent grab samples had nitrite concentrations less than the MDL. The resulting mass loadings ranged from 0.01 to $0.08 \mathrm{~kg} / \mathrm{d}$ and averaged $0.04 \mathrm{~kg} / \mathrm{d}$. These results are presented fully in Table B.5.

\subsubsection{Statistical Analysis}

The Paired t-Test and Wilcoxon Signed Rank Test was used to determine if any significance difference existed between influent and effluent monitored parameters. The Paired $t$-Test was used when observed treatment effects were normally distributed, while the Wilcoxon 
Signed Rank Test was employed with non-normal distribution. The Summaries of the statistical analysis results are presented in Table 4.2.3.1.

Table 4.2.3.1 Facility B Water Quality Monitoring Statistical Analysis Results.

\begin{tabular}{|c|c|c|c|c|}
\hline Parameter & $\begin{array}{l}\text { Normality Test } \\
\text { Passed? (Y/N) }\end{array}$ & Test Used & $\mathbf{P}$ & $\begin{array}{c}\text { Statistically } \\
\text { Significant } \\
\text { Difference? (Y/N; } \\
\mathbf{P}<\mathbf{0 . 0 5 )}\end{array}$ \\
\hline $\mathrm{pH}$ & $\mathrm{Y}$ & Paired $t$-Test & 0.365 & $\mathrm{~N}$ \\
\hline Temperature & $\mathrm{N}$ & $\begin{array}{l}\text { Wilcoxon Signed } \\
\text { Rank Test }\end{array}$ & 0.027 & Y \\
\hline Dissolved Oxygen & $\mathrm{Y}$ & Paired $t$-Test & 0.101 & $\mathrm{~N}$ \\
\hline Spc. Cond. & $\mathrm{N}$ & $\begin{array}{l}\text { Wilcoxon Signed } \\
\text { Rank Test }\end{array}$ & 0.846 & \\
\hline Turbidity & $\mathrm{Y}$ & Paired $t$-Test & 0.439 & $\mathrm{~N}$ \\
\hline TSS & $\mathrm{Y}$ & Paired $t$-Test & 0.001 & $\mathrm{Y}$ \\
\hline Ammonia & $\mathrm{Y}$ & Paired $t$-Test & 0.007 & $\mathrm{Y}$ \\
\hline Nitrate & $\mathrm{N}$ & $\begin{array}{l}\text { Wilcoxon signed } \\
\text { rank test }\end{array}$ & 0.25 & $\mathrm{~N}$ \\
\hline Total P & $\mathrm{Y}$ & Paired $t$-Test & 0.026 & $\mathrm{Y}$ \\
\hline $\mathrm{BOD}_{5}$ & $\mathrm{Y}$ & Paired $t$-Test & 1.000 & $\mathrm{~N}$ \\
\hline Nitrite & $\mathrm{N}$ & $\begin{array}{c}\text { Wilcoxon signed } \\
\text { rank test }\end{array}$ & 1.000 & $\mathrm{~N}$ \\
\hline
\end{tabular}

\subsection{Facility $C$}

\subsubsection{Field Monitoring}

Field monitoring results for Facility C from November 2000 to October 2002 are presented in Table 4.3.1.1. Averages and ranges of concentrations are presented to show extremes due to seasonal variations and impacts of production activities.

Table 4.3.1.1. Field Monitoring Results of Facility $C$.

\begin{tabular}{|c|c|c|c|c|c|}
\hline Site & $\begin{array}{l}\text { pH, Std. Units } \\
\text { average } \\
\text { [range] }\end{array}$ & $\begin{array}{c}\text { Temperature, }{ }^{\circ} \mathrm{C} \\
\text { average } \\
\text { [range] }\end{array}$ & $\begin{array}{c}\text { Spc. Cond., } \mu \mathrm{S} / \mathrm{cm} \\
\text { average } \\
\text { [range] }\end{array}$ & $\begin{array}{c}\mathrm{DO}, \mathrm{mg} / \mathrm{L} \\
\text { average } \\
\text { [range] }\end{array}$ & $\begin{array}{c}\text { Turbidity, NTU } \\
\text { average } \\
\text { [range] }\end{array}$ \\
\hline Influent & $\begin{array}{c}7.81 \\
{[7.24-8.41]}\end{array}$ & $\begin{array}{c}14.48 \\
{[11.2-16.3]}\end{array}$ & $\begin{array}{c}190.2 \\
{[143.2-200.0]}\end{array}$ & $\begin{array}{c}9.43 \\
{[8.39-10.6]}\end{array}$ & $\begin{array}{c}0.90 \\
{[0.46-2.21]}\end{array}$ \\
\hline Effluent & $\begin{array}{c}8.03 \\
{[6.86-8.84]}\end{array}$ & $\begin{array}{c}15.27 \\
{[11.4-19.7]}\end{array}$ & $\begin{array}{c}193.9 \\
{[168.7-204.2]}\end{array}$ & $\begin{array}{c}10.42 \\
{[6.01-12.7]}\end{array}$ & $\begin{array}{c}5.07 \\
{[0.96-15.8]}\end{array}$ \\
\hline
\end{tabular}




\subsubsection{Flow}

Measured flow rates, presented fully in Table C.1, ranged from 1,057 to 2,616 $\mathrm{m}^{3} /$ day and averaged $1,745 \mathrm{~m}^{3} /$ day $(194,480$, and $320 \mathrm{GPM})$.

\subsubsection{2 pH}

Measured pH values are summarized in Table 4.3.1.1 and presented fully in Table C.1. Influent $\mathrm{pH}$ values ranged from 7.24 to 8.41 standard units and averaged 7.81. Effluent $\mathrm{pH}$ values ranged from 6.86 to 8.84 and averaged 8.03 .

\subsubsection{Specific Conductance}

Specific conductance values summarized in Table 4.3.1.1 are presented fully in Table C.2. Influent specific conductance values ranged from 143.2 to $200.0 \mu \mathrm{S} / \mathrm{cm}$ and averaged $190.2 \mu \mathrm{S} / \mathrm{cm}$. Effluent specific conductance values ranged from 168.7 to $204.2 \mu \mathrm{S} / \mathrm{cm}$ and averaged $193.9 \mu \mathrm{S} / \mathrm{cm}$.

\subsubsection{Temperature}

Temperature values, summarized in Table 4.3.1.1, are presented fully in Table C.1. Influent temperatures ranged from 11.2 to $16.3{ }^{\circ} \mathrm{C}\left(52.2\right.$ to $\left.61.3{ }^{\circ} \mathrm{F}\right)$ and averaged $14.5{ }^{\circ} \mathrm{C}(58.1$ $\left.{ }^{\circ} \mathrm{F}\right)$. Effluent temperatures ranged from 11.4 to $19.7^{\circ} \mathrm{C}\left(52.5\right.$ to $\left.67.5{ }^{\circ} \mathrm{F}\right)$ and averaged $15.3{ }^{\circ} \mathrm{C}$ $\left(60.0{ }^{\circ} \mathrm{F}\right)$. Monitored temperatures were in acceptable ranges for the survival of rainbow trout (Meade, 1989).

\subsubsection{Dissolved Oxygen}

Dissolved oxygen concentrations summarized in Table 4.3.1.1, are presented fully in Table C.2. Typically, DO concentrations remained relatively constant in the facility's influent, ranging from 8.39 to $10.6 \mathrm{mg} / \mathrm{L}$, with an average of $9.43 \mathrm{mg} / \mathrm{L}$, and were within the acceptable 
range for salmonid production (5 mg/L to saturation; Heinen 1996). Effluent DO concentrations ranged from 6.01 to $12.7 \mathrm{mg} / \mathrm{L}$ and average $10.4 \mathrm{mg} / \mathrm{L}$.

\subsubsection{Turbidity}

Turbidity values are summarized in Table 4.3.1.1 and presented fully in Table C.2. Influent turbidity ranged from 0.46 to $2.21 \mathrm{NTU}$ and averaged $0.90 \mathrm{NTU}$. Effluent turbidity ranged from 0.96 to $15.8 \mathrm{NTU}$ and averaged 5.07 NTU.

\subsubsection{Grab Samples}

Grab sample results from November 2000 to October 2002 are summarized in Table 4.3.2.1 and presented fully in Table C.3 to C.6. Averages and ranges of concentration and loading are presented to show extremes due to seasonal variations and impacts of production activities.

Table 4.3.2.1 Grab Sample Results of Facility C.

\begin{tabular}{|c|c|c|c|c|c|}
\hline Site & $\begin{array}{c}\text { TSS } \\
\text { average } \\
\text { [range] }\end{array}$ & $\begin{array}{l}\text { BOD }_{5} \\
\text { average } \\
\text { [range] }\end{array}$ & $\begin{array}{c}\mathrm{NH}_{3} \\
\text { average } \\
\text { [range] }\end{array}$ & $\begin{array}{c}\mathrm{NO}_{3}^{-} \\
\text {average } \\
\text { [range] }\end{array}$ & $\begin{array}{c}\text { TP } \\
\text { average } \\
\text { [range] }\end{array}$ \\
\hline $\begin{array}{l}\text { Influent } \\
\text { concentration, } \\
\mathrm{mg} / \mathrm{L}\end{array}$ & $\begin{array}{c}2.67 \\
{[2.0-6.0]}\end{array}$ & $\begin{array}{c}1.43^{\dagger} \\
{[1.43 \dagger]}\end{array}$ & $\begin{array}{c}0.09^{\dagger} \\
{\left[0.01^{\dagger}-0.18\right]}\end{array}$ & $\begin{array}{c}0.14^{\dagger} \\
{\left[0.01^{\dagger}-0.55\right]}\end{array}$ & $\begin{array}{c}0.05^{\dagger} \\
{\left[0.005^{\dagger}-0.16\right]}\end{array}$ \\
\hline $\begin{array}{l}\text { Effluent } \\
\text { concentration, } \\
\mathrm{mg} / \mathrm{L}\end{array}$ & $\begin{array}{c}6.87 \\
{[2.0-14.0]}\end{array}$ & $\begin{array}{c}1.71^{\dagger} \\
{\left[1.43^{\dagger}-4.27\right]}\end{array}$ & $\begin{array}{c}0.21 \\
{[0.08-0.45]}\end{array}$ & $\begin{array}{c}0.07 \\
{[0.02-0.15]}\end{array}$ & $\begin{array}{c}0.09^{\dagger} \\
{\left[0.005^{\dagger}-0.26\right]}\end{array}$ \\
\hline $\begin{array}{l}\text { Effluent loading, } \\
\mathrm{kg} / \mathrm{d}\end{array}$ & $\begin{array}{c}12.3 \\
{[2.11-25.0]}\end{array}$ & $\begin{array}{c}2.96^{\dagger} \\
{\left[1.51^{\dagger}-7.03\right]}\end{array}$ & $\begin{array}{c}0.37 \\
{[0.12-0.74]}\end{array}$ & $\begin{array}{c}0.12 \\
{[0.03-0.27]}\end{array}$ & $\begin{array}{c}0.15^{\dagger} \\
{\left[0.001^{\dagger}-0.49\right]}\end{array}$ \\
\hline \multicolumn{2}{|c|}{$\dagger$ Presented valued was calculated by: } & $\frac{\mathrm{MDL}}{2}$ & & & \\
\hline
\end{tabular}


TSS concentrations are summarized in Table 4.3.2.1 and presented fully in Table C.3. Influent TSS concentrations ranged from 2.0 to $6.0 \mathrm{mg} / \mathrm{L}$ and averaged $2.67 \mathrm{mg} / \mathrm{L}$. Effluent TSS concentrations ranged from 2.0 to $14.0 \mathrm{mg} / \mathrm{L}$ and averaged $6.87 \mathrm{mg} / \mathrm{L}$. TSS loadings ranged from 2.11 to $25.0 \mathrm{~kg} / \mathrm{d}$ and averaged $12.34 \mathrm{~kg} /$ day.

\subsubsection{Five Day Biochemical Oxygen Demand $\left(B O D_{5}\right)$}

All influent grab samples analyzed for $\mathrm{BOD}_{5}$ were below the MDL. Effluent $\mathrm{BOD}_{5}$ concentrations ranged from 1.43 to $4.27 \mathrm{mg} / \mathrm{L}$ and averaged $1.71 \mathrm{mg} / \mathrm{L}$. Mass loadings of $\mathrm{BOD}_{5}$ ranged from 1.51 to $7.03 \mathrm{~kg} / \mathrm{d}$ and averaged $2.96 \mathrm{~kg} / \mathrm{d}$. Results are summarized in Table 4.3.2.1 and presented fully in Table C.6.

\subsubsection{Total Ammonia Nitrogen (TAN)}

Ammonia concentrations and mass loadings are summarized in Table 4.3.2.1 and presented fully in Table C.3 and C.4. Influent $\mathrm{NH}_{3}$ concentrations ranged from 0.01 to 0.18 $\mathrm{mg} / \mathrm{L}$ and averaged $0.09 \mathrm{mg} / \mathrm{L}$. Effluent $\mathrm{NH}_{3}$ concentrations ranged from 0.08 to $0.45 \mathrm{mg} / \mathrm{L}$ and averaged $0.21 \mathrm{mg} / \mathrm{L}$. Effluent mass loadings ranged from 0.12 to $0.74 \mathrm{~kg} / \mathrm{d}$ and averaged 0.37 $\mathrm{kg} / \mathrm{d}$.

\subsubsection{Nitrate $\left(\mathrm{NO}_{3}^{-}\right)$}

Nitrate concentrations and mass loadings are summarized in Table 4.3.2.1 and presented fully in Table C.4 and C.5. Influent nitrate concentrations ranged from 0.01 to $0.55 \mathrm{mg} / \mathrm{L}$ and averaged $0.14 \mathrm{mg} / \mathrm{L}$. Effluent nitrate concentrations ranged from 0.02 to $0.15 \mathrm{mg} / \mathrm{L}$ and averaged $0.07 \mathrm{mg} / \mathrm{L}$. Effluent mass loadings ranged from 0.03 to $0.27 \mathrm{~kg} / \mathrm{d}$ and averaged 0.12 $\mathrm{kg} / \mathrm{d}$.

\subsubsection{Total Phosphorus (TP)}


Total phosphorus concentrations and mass loadings are summarized in Table 4.3.2.1 and presented fully in Table C.6. Influent total phosphorus concentrations ranged from 0.005 to 0.16 $\mathrm{mg} / \mathrm{L}$ and averaged $0.05 \mathrm{mg} / \mathrm{L}$. Effluent total phosphorus concentrations ranged from 0.005 to $0.26 \mathrm{mg} / \mathrm{L}$ and averaged $0.09 \mathrm{mg} / \mathrm{L}$. Effluent mass loadings ranged from 0.001 to $0.49 \mathrm{~kg} / \mathrm{d}$ and averaged $0.15 \mathrm{~kg} / \mathrm{d}$.

\subsubsection{Nitrite $\left(\mathrm{NO}_{2}^{-}\right)$}

All influent and effluent grab samples had nitrite concentrations less than the MDL. The resulting mass loadings ranged from 0.01 to $0.03 \mathrm{~kg} / \mathrm{d}$ and averaged $0.02 \mathrm{~kg} / \mathrm{d}$. These results are presented fully in Table C.5.

\subsubsection{Statistical Analysis}

The Paired $t$-Test and Wilcoxon Signed Rank Test was used to determine if any significance difference existed between influent and effluent monitored parameters. The Paired $t$-Test was used when observed treatment effects were normally distributed, while the Wilcoxon Signed Rank Test was employed with non-normal distribution. The Summaries of the statistical analysis results are presented in Table 4.3.3.1. 
Table 4.3.3.1 Facility C Water Quality Monitoring Statistical Analysis Results.

\begin{tabular}{|c|c|c|c|c|}
\hline Parameter & $\begin{array}{l}\text { Normality Test } \\
\text { Passed? (Y/N) }\end{array}$ & Test Used & $\mathbf{P}$ & $\begin{array}{c}\text { Statistically } \\
\text { Significant } \\
\text { Difference? (Y/N; } \\
\mathbf{P}<\mathbf{0 . 0 5 )} \\
\end{array}$ \\
\hline $\mathrm{pH}$ & $\mathrm{Y}$ & Paired $t$-Test & 0.321 & $\mathrm{~N}$ \\
\hline Temperature & $\mathrm{Y}$ & Paired $t$-Test & 0.149 & $\mathrm{~N}$ \\
\hline Dissolved Oxygen & $\mathrm{Y}$ & Paired $t$-Test & 0.152 & $\mathrm{~N}$ \\
\hline Spc. Cond. & $\mathrm{N}$ & $\begin{array}{l}\text { Wilcoxon Signed } \\
\text { Rank Test }\end{array}$ & 0.275 & $\mathrm{~N}$ \\
\hline Turbidity & $\mathrm{Y}$ & Paired $t$-Test & 0.017 & $\mathrm{Y}$ \\
\hline TSS & $\mathrm{Y}$ & Paired $t$-Test & 0.018 & $\mathrm{Y}$ \\
\hline Ammonia & $\mathrm{Y}$ & Paired $t$-Test & 0.021 & $\mathrm{Y}$ \\
\hline Nitrate & $\mathrm{N}$ & $\begin{array}{l}\text { Wilcoxon signed } \\
\text { rank test }\end{array}$ & 0.275 & $\mathrm{~N}$ \\
\hline Total P & Y & Paired $t$-Test & 0.009 & Y \\
\hline $\mathrm{BOD}_{5}$ & $\mathrm{~N}$ & $\begin{array}{l}\text { Wilcoxon Signed } \\
\text { Rank Test }\end{array}$ & 1.000 & $\mathrm{~N}$ \\
\hline Nitrite & $\mathrm{N}$ & $\begin{array}{c}\text { Wilcoxon Signed } \\
\text { Rank Test }\end{array}$ & 1.000 & $\mathrm{~N}$ \\
\hline
\end{tabular}

\subsection{Facility D}

\subsubsection{Field Monitoring}

Field monitoring results for Facility D from January 2001 to June 2002 are presented in Table 4.4.1.1. Averages and ranges of concentrations are presented to show extremes due to seasonal variations and impacts of production activities.

Table 4.4.1.1. Field Monitoring Results of Facility D.

\begin{tabular}{cccccc}
\hline Site & $\begin{array}{c}\mathbf{p H}, \text { Std. Units } \\
\text { average } \\
\text { [range] }\end{array}$ & $\begin{array}{c}\text { Temperature, }{ }^{\circ} \mathbf{C} \\
\text { average } \\
\text { [range] }\end{array}$ & $\begin{array}{c}\text { Spc. Cond., } \mu \mathbf{S} / \mathbf{c m} \\
\text { average } \\
\text { [range] }\end{array}$ & $\begin{array}{c}\text { DO, } \mathbf{~ m g / L} \\
\text { average } \\
\text { [range] }\end{array}$ & $\begin{array}{c}\text { Turbidity, NTU } \\
\text { average } \\
\text { [range] }\end{array}$ \\
\hline \multirow{2}{*}{ Influent } & 7.69 & 11.3 & 271.2 & 9.33 & 3.28 \\
& {$[7.25-8.06]$} & {$[9.30-13.0]$} & {$[193.6-323.0]$} & {$[6.48-11.19]$} & {$[1.03-7.47]$} \\
Effluent & 7.81 & 12.2 & & & \\
& {$[7.26-8.48]$} & {$[10.3-13.3]$} & {$[222.1-336.1]$} & {$[5.96-10.16]$} & {$[2.02-8.13]$} \\
\hline
\end{tabular}

\subsubsection{Flow}


Measured flow rates, presented fully in Table D.1, ranged from 932 to $5,178 \mathrm{~m}^{3} /$ day and averaged $2,741 \mathrm{~m}^{3} /$ day $(171,950$, and $503 \mathrm{GPM})$.

\subsubsection{2 $\mathrm{pH}$}

Measured $\mathrm{pH}$ values are summarized in Table 4.4.1.1 and presented fully in Table D.1. Influent $\mathrm{pH}$ values ranged from 7.25 to 8.06 standard units and averaged 7.69. Effluent $\mathrm{pH}$ values ranged from 7.26 to 8.48 and averaged 7.81 .

\subsubsection{Specific Conductance}

Specific conductance values summarized in Table 4.4.1.1 are presented fully in Table D.2. Influent specific conductance values ranged from 193.6 to $323.0 \mu \mathrm{S} / \mathrm{cm}$ and averaged $271.2 \mu \mathrm{S} / \mathrm{cm}$. Effluent specific conductance values ranged from 222.1 to $336.1 \mu \mathrm{S} / \mathrm{cm}$ and averaged $293.4 \mu \mathrm{S} / \mathrm{cm}$.

\subsubsection{Temperature}

Temperature values, summarized in Table 4.4.1.1, are presented fully in Table D.1. Influent temperatures ranged from 9.3 to $13.0{ }^{\circ} \mathrm{C}\left(48.7\right.$ to $\left.55.4{ }^{\circ} \mathrm{F}\right)$ and averaged $11.3{ }^{\circ} \mathrm{C}(52.3$ $\left.{ }^{\circ} \mathrm{F}\right)$. Effluent temperatures ranged from 10.3 to $13.3{ }^{\circ} \mathrm{C}\left(50.5\right.$ to $\left.56.0{ }^{\circ} \mathrm{F}\right)$ and averaged $12.2{ }^{\circ} \mathrm{C}$ $\left(54.0{ }^{\circ} \mathrm{F}\right)$. Monitored temperatures were in acceptable ranges for the survival of rainbow trout (Meade, 1989).

\subsubsection{Dissolved Oxygen}

Dissolved oxygen concentrations summarized in Table 4.4.1.1, are presented fully in Table D.2. Typically, DO concentrations remained relatively constant in the facility's influent, ranging from 6.48 to $11.19 \mathrm{mg} / \mathrm{L}$, with an average of $9.33 \mathrm{mg} / \mathrm{L}$, and were within the acceptable range for salmonid production (5 mg/L to saturation; Heinen 1996). Effluent DO concentrations ranged from 5.96 to $10.16 \mathrm{mg} / \mathrm{L}$ and average $8.07 \mathrm{mg} / \mathrm{L}$. 


\subsubsection{Turbidity}

Turbidity values are summarized in Table 4.4.1.1 and presented fully in Table D.2. Influent turbidity ranged from 1.03 to $7.47 \mathrm{NTU}$ and averaged 3.28 NTU. Effluent turbidity ranged from 2.02 to $8.13 \mathrm{NTU}$ and averaged $4.45 \mathrm{NTU}$.

\subsubsection{Grab Samples}

Grab sample results from January 2001 to June 2002 are summarized in Table 4.4.2.1 and presented fully in Table D.3 to D.6. Averages and ranges of concentration and loading are presented to show extremes due to seasonal variations and impacts of production activities.

Table 4.4.2.1 Grab Sample Results of Facility D.

\begin{tabular}{|c|c|c|c|c|c|}
\hline Site & $\begin{array}{c}\text { TSS } \\
\text { average } \\
\text { [range] }\end{array}$ & $\begin{array}{c}\text { BOD }_{5} \\
\text { average } \\
\text { [range] }\end{array}$ & $\begin{array}{c}\mathrm{NH}_{3} \\
\text { average } \\
\text { [range] }\end{array}$ & $\begin{array}{c}\mathrm{NO}_{3}^{-} \\
\text {average } \\
\text { [range] }\end{array}$ & $\begin{array}{c}\text { TP } \\
\text { average } \\
\text { [range] }\end{array}$ \\
\hline $\begin{array}{l}\text { Influent } \\
\text { concentration, } \\
\mathrm{mg} / \mathrm{L}\end{array}$ & $\begin{array}{c}3.00^{\dagger} \\
{\left[0.5^{\dagger}-8.0\right]}\end{array}$ & $\begin{array}{c}1.43^{\dagger} \\
{[1.43 \dagger]}\end{array}$ & $\begin{array}{c}0.05^{\dagger} \\
{\left[0.01^{\dagger}-0.15\right]}\end{array}$ & $\begin{array}{c}1.00 \\
{[0.10-1.37]}\end{array}$ & $\begin{array}{c}0.02^{\dagger} \\
{\left[0.005^{\dagger}-0.039\right]}\end{array}$ \\
\hline $\begin{array}{l}\text { Effluent } \\
\text { concentration, } \\
\mathrm{mg} / \mathrm{L}\end{array}$ & $\begin{array}{c}10.88 \\
{[5.50-25.0]}\end{array}$ & $\begin{array}{c}2.42^{\dagger} \\
{\left[1.43^{\dagger}-4.96\right]}\end{array}$ & $\begin{array}{c}0.23 \\
{[0.10-0.59]}\end{array}$ & $\begin{array}{c}1.00 \\
{[0.12-1.44]}\end{array}$ & $\begin{array}{c}0.19 \\
{[0.03-0.37]}\end{array}$ \\
\hline $\begin{array}{l}\text { Effluent loading, } \\
\mathrm{kg} / \mathrm{d}\end{array}$ & $\begin{array}{c}36.1 \\
{[6.79-110]}\end{array}$ & $\begin{array}{c}6.29^{\dagger} \\
{\left[1.33^{\dagger}-18.4\right]}\end{array}$ & $\begin{array}{c}0.52 \\
{[0.10-1.02]}\end{array}$ & $\begin{array}{c}2.77 \\
{[0.25-5.16]}\end{array}$ & $\begin{array}{c}0.46 \\
{[0.11-1.44]}\end{array}$ \\
\hline & & $\frac{\mathrm{MDL}}{2}$ & & & \\
\hline
\end{tabular}

\subsubsection{Total Suspended Solids (TSS)}

TSS concentrations are summarized in Table 4.4.2.1 and presented fully in Table D.3. Influent TSS concentrations ranged from 0.5 to $8.0 \mathrm{mg} / \mathrm{L}$ and averaged $3.00 \mathrm{mg} / \mathrm{L}$. Effluent TSS concentrations ranged from 5.50 to $25.0 \mathrm{mg} / \mathrm{L}$ and averaged $10.88 \mathrm{mg} / \mathrm{L}$. TSS loadings ranged from 6.79 to $110 \mathrm{~kg} / \mathrm{d}$ and averaged $36.1 \mathrm{~kg} / \mathrm{day}$. 


\subsubsection{Five Day Biochemical Oxygen Demand $\left(B O D_{5}\right)$}

All influent grab samples analyzed for $\mathrm{BOD}_{5}$ were below the MDL. Effluent $\mathrm{BOD}_{5}$ concentrations ranged from 1.43 to $4.96 \mathrm{mg} / \mathrm{L}$ and averaged $2.42 \mathrm{mg} / \mathrm{L}$. Mass loadings of $\mathrm{BOD}_{5}$ ranged from 1.33 to $18.4 \mathrm{~kg} / \mathrm{d}$ and averaged $6.29 \mathrm{~kg} / \mathrm{d}$. Results are summarized in Table 4.4.2.1 and presented fully in Table D.6.

\subsubsection{Total Ammonia Nitrogen (TAN)}

Ammonia concentrations and mass loadings are summarized in Table 4.4.2.1 and presented fully in Tables D.3 and D.4. Influent $\mathrm{NH}_{3}$ concentrations ranged from 0.01 to 0.15 $\mathrm{mg} / \mathrm{L}$ and averaged $0.05 \mathrm{mg} / \mathrm{L}$. Effluent $\mathrm{NH}_{3}$ concentrations ranged from 0.10 to $0.59 \mathrm{mg} / \mathrm{L}$ and averaged $0.23 \mathrm{mg} / \mathrm{L}$. Effluent mass loadings ranged from 0.10 to $1.02 \mathrm{~kg} / \mathrm{d}$ and averaged 0.52 $\mathrm{kg} / \mathrm{d}$.

\subsubsection{Nitrate $\left(\mathrm{NO}_{3}{ }^{-}\right)$}

Nitrate concentrations and mass loadings are summarized in Table 4.4.2.1 and presented fully in Tables D.4 and D.5. Influent nitrate concentrations ranged from 0.10 to $1.37 \mathrm{mg} / \mathrm{L}$ and averaged $1.00 \mathrm{mg} / \mathrm{L}$. Effluent nitrate concentrations ranged from 0.12 to $1.44 \mathrm{mg} / \mathrm{L}$ and averaged $1.00 \mathrm{mg} / \mathrm{L}$. Effluent mass loadings ranged from 0.25 to $5.16 \mathrm{~kg} / \mathrm{d}$ and averaged 2.77 $\mathrm{kg} / \mathrm{d}$.

\subsubsection{Total Phosphorus (TP)}

Total phosphorus concentrations and mass loadings are summarized in Table 4.4.2.1 and presented fully in Table D.6. Influent total phosphorus concentrations ranged from 0.005 to $0.039 \mathrm{mg} / \mathrm{L}$ and averaged $0.02 \mathrm{mg} / \mathrm{L}$. Effluent total phosphorus concentrations ranged from 0.03 to $0.37 \mathrm{mg} / \mathrm{L}$ and averaged $0.19 \mathrm{mg} / \mathrm{L}$. Effluent mass loadings ranged from 0.11 to 1.44 $\mathrm{kg} / \mathrm{d}$ and averaged $0.46 \mathrm{~kg} / \mathrm{d}$. 


\subsubsection{Nitrite $\left(\mathrm{NO}_{2}^{-}\right)$}

All influent and effluent grab samples had nitrite concentrations less than the MDL. The resulting mass loadings ranged from 0.01 to $0.05 \mathrm{~kg} / \mathrm{d}$ and averaged $0.03 \mathrm{~kg} / \mathrm{d}$. These results are presented fully in Table D.5.

\subsubsection{Statistical Analysis}

The Paired t-Test and Wilcoxon Signed Rank Test was used to determine if any significance difference existed between influent and effluent monitored parameters. The Paired $t$-Test was used when observed treatment effects were normally distributed, while the Wilcoxon Signed Rank Test was employed with non-normal distribution. The Summaries of the statistical analysis results are presented in Table 4.4.3.1.

Table 4.4.3.1 Facility D Water Quality Monitoring Statistical Analysis Results.

\begin{tabular}{|c|c|c|c|c|}
\hline Parameter & $\begin{array}{l}\text { Normality Test } \\
\text { Passed? (Y/N) }\end{array}$ & Test Used & $\mathbf{P}$ & $\begin{array}{c}\text { Statistically } \\
\text { Significant } \\
\text { Difference? (Y/N; } \\
\mathbf{P}<\mathbf{0 . 0 5 )} \\
\end{array}$ \\
\hline $\mathrm{pH}$ & $\mathrm{Y}$ & Paired $t$-Test & 0.298 & $\mathrm{~N}$ \\
\hline Temperature & Y & Paired $t$-Test & 0.009 & Y \\
\hline Dissolved Oxygen & $\mathrm{Y}$ & Paired $t$-Test & 0.026 & $\mathrm{Y}$ \\
\hline Spc. Cond. & $\mathrm{N}$ & $\begin{array}{l}\text { Wilcoxon Signed } \\
\text { Rank Test }\end{array}$ & 0.031 & Y \\
\hline Turbidity & Y & Paired $t$-Test & 0.007 & Y \\
\hline TSS & $\mathrm{Y}$ & Paired $t$-Test & 0.017 & $\mathrm{Y}$ \\
\hline Ammonia & $\mathrm{Y}$ & Paired $t$-Test & 0.025 & Y \\
\hline Nitrate & $\mathrm{N}$ & $\begin{array}{l}\text { Wilcoxon signed } \\
\text { rank test }\end{array}$ & 0.945 & $\mathrm{~N}$ \\
\hline Total P & Y & Paired $t$-Test & 0.008 & Y \\
\hline $\mathrm{BOD}_{5}$ & $\mathrm{~N}$ & $\begin{array}{l}\text { Wilcoxon Signed } \\
\text { Rank Test }\end{array}$ & 0.250 & $\mathrm{~N}$ \\
\hline Nitrite & $\mathrm{N}$ & $\begin{array}{c}\text { Wilcoxon Signed } \\
\text { Rank Test }\end{array}$ & 1.000 & $\mathrm{~N}$ \\
\hline
\end{tabular}




\subsection{Facility $E$}

\subsubsection{Field Monitoring}

Field monitoring results for Facility E from January 2001 to June 2002 are presented in Table 4.5.1.1. Averages and ranges of concentrations are presented to show extremes due to seasonal variations and impacts of production activities.

Table 4.5.1.1. Field Monitoring Results of Facility E.

\begin{tabular}{|c|c|c|c|c|c|}
\hline Site & $\begin{array}{l}\text { pH, Std. Units } \\
\text { average } \\
\text { [range] }\end{array}$ & $\begin{array}{c}\text { Temperature, }{ }^{\circ} \mathrm{C} \\
\text { average } \\
\text { [range] }\end{array}$ & $\begin{array}{c}\text { Spc. Cond., } \mu \mathrm{S} / \mathrm{cm} \\
\text { average } \\
\text { [range] }\end{array}$ & $\begin{array}{c}\mathrm{DO}, \mathrm{mg} / \mathrm{L} \\
\text { average } \\
\text { [range] }\end{array}$ & $\begin{array}{l}\text { Turbidity, NTU } \\
\text { average } \\
\text { [range] }\end{array}$ \\
\hline Influent & $\begin{array}{c}6.90 \\
{[6.33-7.20]}\end{array}$ & $\begin{array}{c}13.5 \\
{[13.1-13.7]}\end{array}$ & $\begin{array}{c}467.1 \\
{[391.2-545.0]}\end{array}$ & $\begin{array}{c}6.14 \\
{[5.82-6.97]}\end{array}$ & $\begin{array}{c}4.55 \\
{[3.99-5.28]}\end{array}$ \\
\hline Effluent & $\begin{array}{c}7.43 \\
{[6.86-7.81]}\end{array}$ & $\begin{array}{c}13.7 \\
{[12.9-14.1]}\end{array}$ & $\begin{array}{c}499.4 \\
{[430.0-548.0]}\end{array}$ & $\begin{array}{c}7.66 \\
{[5.74-8.88]}\end{array}$ & $\begin{array}{c}5.64 \\
{[3.63-8.32]}\end{array}$ \\
\hline $\begin{array}{l}\text { OLS Pond } \\
\text { Effluent }\end{array}$ & $\begin{array}{c}7.41 \\
{[6.85-7.90]}\end{array}$ & $\begin{array}{c}14.6 \\
{[11.8-16.5]}\end{array}$ & $\begin{array}{c}507.3 \\
{[237.0-840.0]}\end{array}$ & $\begin{array}{c}9.22 \\
{[7.92-12.5]}\end{array}$ & $\begin{array}{c}5.05 \\
{[3.63-7.50]}\end{array}$ \\
\hline
\end{tabular}

\subsubsection{Flow}

Measured effluent flow rates, presented fully in Tables E.1 and E.7, ranged from 5,374 to $16,084 \mathrm{~m}^{3} /$ day and averaged $10,068 \mathrm{~m}^{3} /$ day $(986,2,951$, and 1,825 GPM). OLS Pond flow rates ranged from 343 to $3063 \mathrm{~m}^{3} /$ day and averaged $2,276 \mathrm{~m}^{3} /$ day $(63,562$, and $418 \mathrm{GPM})$.

\subsubsection{2 $\mathrm{pH}$}

Measured $\mathrm{pH}$ values are summarized in Table 4.5.1.1 and presented fully in Tables E.1 and E.7. Influent $\mathrm{pH}$ values ranged from 6.33 to 7.20 standard units and averaged 6.90. Effluent $\mathrm{pH}$ values ranged from 6.86 to 7.81 and averaged 7.43. OLS Pond effluent $\mathrm{pH}$ values ranged from 6.85 to 7.90 standard units and averaged 7.41 . 


\subsubsection{Specific Conductance}

Specific conductance values summarized in Table 4.5.1.1 are presented fully in Tables E.2 and E.8. Influent specific conductance values ranged from 391.2 to $545.0 \mu \mathrm{S} / \mathrm{cm}$ and averaged $467.1 \mu \mathrm{S} / \mathrm{cm}$. Effluent specific conductance values ranged from 430.0 to 548.0 $\mu \mathrm{S} / \mathrm{cm}$ and averaged $499.4 \mu \mathrm{S} / \mathrm{cm}$. OLS Pond effluent specific conductance values ranged from 237.0 to $840.0 \mu \mathrm{S} / \mathrm{cm}$ and averaged 507.3

\subsubsection{Temperature}

Temperature values, summarized in Table 4.5.1.1, are presented fully in Tables E.1 and E.7. Influent temperatures ranged from 13.1 to $13.7{ }^{\circ} \mathrm{C}\left(55.6\right.$ to $\left.56.7{ }^{\circ} \mathrm{F}\right)$ and averaged $13.5^{\circ} \mathrm{C}$ $\left(56.3{ }^{\circ} \mathrm{F}\right)$. Effluent temperatures ranged from 12.9 to $14.1{ }^{\circ} \mathrm{C}\left(55.2\right.$ to $\left.57.4{ }^{\circ} \mathrm{F}\right)$ and averaged 13.7 ${ }^{\circ} \mathrm{C}\left(56.7{ }^{\circ} \mathrm{F}\right)$. OLS Pond effluent temperatures ranged from 11.8 to $16.5^{\circ} \mathrm{C}\left(53.2\right.$ to $\left.61.7^{\circ} \mathrm{F}\right)$ and averaged $14.6{ }^{\circ} \mathrm{C}\left(58.3{ }^{\circ} \mathrm{F}\right)$. Monitored temperatures were in acceptable ranges for the survival of rainbow trout (Meade, 1989).

\subsubsection{Dissolved Oxygen}

Dissolved oxygen concentrations summarized in Table 4.5.1.1, are presented fully in Tables E.2 and E.7. Typically, DO concentrations remained relatively constant in the facility's influent, ranging from 5.82 to $6.97 \mathrm{mg} / \mathrm{L}$, with an average of $6.14 \mathrm{mg} / \mathrm{L}$, and were within the acceptable range for salmonid production ( $5 \mathrm{mg} / \mathrm{L}$ to saturation; Heinen 1996). Effluent DO concentrations ranged from 5.74 to $8.88 \mathrm{mg} / \mathrm{L}$ and average $7.66 \mathrm{mg} / \mathrm{L}$. OLS Pond effluent DO concentrations ranged from 7.92 to $12.5 \mathrm{mg} / \mathrm{L}$ and average $9.22 \mathrm{mg} / \mathrm{L}$

\subsubsection{Turbidity}

Turbidity values are summarized in Table 4.5.1.1 and presented fully in Table E.2 and E.7. Influent turbidity ranged from 3.99 to $5.28 \mathrm{NTU}$ and averaged $4.55 \mathrm{NTU}$. Effluent 
turbidity ranged from 3.63 to 8.32 NTU and averaged 5.64 NTU. OLS Pond effluent turbidity ranged from 3.63 to $7.50 \mathrm{NTU}$ and averaged 5.05 NTU

\subsubsection{Grab Samples}

Grab sample results from January 2001 to June 2002 are summarized in Table 4.5.2.1 and presented fully in Tables E.3 to E.6 and E.8 to E.9. Averages and ranges of concentration and loading are presented to show extremes due to seasonal variations and impacts of production activities.

Table 4.5.2.1 Grab Sample Results of Facility E.

\begin{tabular}{|c|c|c|c|c|c|}
\hline Site & $\begin{array}{c}\text { TSS } \\
\text { average } \\
\text { [range] }\end{array}$ & $\begin{array}{c}\mathrm{BOD}_{5} \\
\text { average } \\
\text { [range] }\end{array}$ & $\begin{array}{c}\mathrm{NH}_{3} \\
\text { average } \\
\text { [range] }\end{array}$ & $\begin{array}{c}\mathrm{NO}_{3}^{-} \\
\text {average } \\
\text { [range] }\end{array}$ & $\begin{array}{c}\text { TP } \\
\text { average } \\
\text { [range] }\end{array}$ \\
\hline $\begin{array}{l}\text { Influent } \\
\text { concentration, } \\
\mathrm{mg} / \mathrm{L}\end{array}$ & $\begin{array}{c}2.38 \\
{[1.00-4.00]}\end{array}$ & $\begin{array}{c}1.43^{\dagger} \\
{\left[1.43^{\dagger}\right]}\end{array}$ & $\begin{array}{c}0.24 \\
{[0.05-1.23]}\end{array}$ & $\begin{array}{c}0.10^{\dagger} \\
{\left[0.01^{\dagger}-0.22\right]}\end{array}$ & $\begin{array}{c}0.02^{\dagger} \\
{\left[0.005^{\dagger}-0.07\right]}\end{array}$ \\
\hline $\begin{array}{l}\text { Effluent } \\
\text { concentration, } \\
\mathrm{mg} / \mathrm{L}\end{array}$ & $\begin{array}{c}7.90 \\
{[5.00-10.0]}\end{array}$ & $\begin{array}{c}4.36^{\dagger} \\
{\left[1.43^{\dagger}-6.04\right]}\end{array}$ & $\begin{array}{c}0.31 \\
{[0.15-0.48]}\end{array}$ & $\begin{array}{c}0.18 \\
{[0.03-0.27]}\end{array}$ & $\begin{array}{c}0.19 \\
{\left[0.005^{\dagger}-0.29\right]}\end{array}$ \\
\hline $\begin{array}{l}\text { Effluent loading, } \\
\mathrm{kg} / \mathrm{d}\end{array}$ & $\begin{array}{c}81.2 \\
{[32.2-161]}\end{array}$ & $\begin{array}{c}46.9^{\dagger} \\
{\left[7.68^{\dagger}-76.9\right]}\end{array}$ & $\begin{array}{c}3.06 \\
{[1.13-5.21]}\end{array}$ & $\begin{array}{c}1.79 \\
{[0.33-2.88]}\end{array}$ & $\begin{array}{c}1.35^{\dagger} \\
{\left[0.01^{\dagger}-2.76\right]}\end{array}$ \\
\hline $\begin{array}{l}\text { OLS Pond } \\
\text { effluent } \\
\text { concentration, } \\
\mathrm{mg} / \mathrm{L}\end{array}$ & $\begin{array}{c}5.69^{\dagger} \\
{[0.5-8.00]}\end{array}$ & $\begin{array}{c}1.70^{\dagger} \\
{\left[1.43^{\dagger}-3.56\right]}\end{array}$ & $\begin{array}{c}0.30 \\
{[0.13-0.54]}\end{array}$ & $\begin{array}{c}0.16 \\
{[0.10-0.19]}\end{array}$ & $\begin{array}{c}0.06^{\dagger} \\
{\left[0.005^{\dagger}-0.10\right]}\end{array}$ \\
\hline $\begin{array}{l}\text { OLS Pond } \\
\text { effluent loading, } \\
\mathrm{kg} / \mathrm{d}\end{array}$ & $\begin{array}{c}12.6^{\dagger} \\
{[1.72-21.0]}\end{array}$ & $\begin{array}{c}4.07^{\dagger} \\
{\left[0.49^{\dagger}-10.9\right]}\end{array}$ & $\begin{array}{c}0.68 \\
{[0.14-1.65]}\end{array}$ & $\begin{array}{c}0.34 \\
{[0.06-0.57]}\end{array}$ & $\begin{array}{c}0.20^{\dagger} \\
{\left[0.02-0.55^{\dagger}\right]}\end{array}$ \\
\hline
\end{tabular}

$\dagger$ Presented valued was calculated by: $\frac{\mathrm{MDL}}{2}$.

\subsubsection{Total Suspended Solids (TSS)}

TSS concentrations are summarized in Table 4.5.2.1 and presented fully in Tables E.3 and E.8. Influent TSS concentrations ranged from 1.00 to $4.00 \mathrm{mg} / \mathrm{L}$ and averaged $2.38 \mathrm{mg} / \mathrm{L}$. 
Effluent TSS concentrations ranged from 5.00 to $10.0 \mathrm{mg} / \mathrm{L}$ and averaged $7.90 \mathrm{mg} / \mathrm{L}$. TSS effluent loadings ranged from 32.2 to $161 \mathrm{~kg} / \mathrm{d}$ and averaged $81.2 \mathrm{~kg} /$ day. OLS Pond effluent TSS concentrations ranged from 0.50 to $8.00 \mathrm{mg} / \mathrm{L}$ and averaged $5.69 \mathrm{mg} / \mathrm{L}$. OLS Pond effluent loadings ranged from 1.72 to $21.0 \mathrm{~kg} / \mathrm{d}$ and averaged $12.6 \mathrm{~kg} / \mathrm{day}$.

\subsubsection{Five Day Biochemical Oxygen Demand $\left(B O D_{5}\right)$}

All influent grab samples analyzed for $\mathrm{BOD}_{5}$ were below the MDL. Effluent $\mathrm{BOD}_{5}$ concentrations ranged from 1.43 to $6.04 \mathrm{mg} / \mathrm{L}$ and averaged $4.36 \mathrm{mg} / \mathrm{L}$. Mass loadings of $\mathrm{BOD}_{5}$ ranged from 7.68 to $76.9 \mathrm{~kg} / \mathrm{d}$ and averaged $46.9 \mathrm{~kg} / \mathrm{d}$. OLS Pond effluent $\mathrm{BOD}_{5}$ concentrations ranged from 1.43 to $3.56 \mathrm{mg} / \mathrm{L}$ and averaged $1.70 \mathrm{mg} / \mathrm{L}$. OLS Pond mass loadings of $\mathrm{BOD}_{5}$ ranged from 0.49 to $10.9 \mathrm{~kg} / \mathrm{d}$ and averaged $4.07 \mathrm{~kg} / \mathrm{d}$ Results are summarized in Table 4.5.2.1 and presented fully in Tables E.6 and E.9.

\subsubsection{Total Ammonia Nitrogen (TAN)}

Ammonia concentrations and mass loadings are summarized in Table 4.5.2.1 and presented fully in Tables E.3, E.4, and E.8. Influent $\mathrm{NH}_{3}$ concentrations ranged from 0.05 to $0.1 .23 \mathrm{mg} / \mathrm{L}$ and averaged $0.24 \mathrm{mg} / \mathrm{L}$. Effluent $\mathrm{NH}_{3}$ concentrations ranged from 0.15 to 0.48 $\mathrm{mg} / \mathrm{L}$ and averaged $0.31 \mathrm{mg} / \mathrm{L}$. Effluent mass loadings ranged from 1.13 to $5.21 \mathrm{~kg} / \mathrm{d}$ and averaged $3.06 \mathrm{~kg} / \mathrm{d}$. OLS Pond effluent $\mathrm{NH}_{3}$ concentrations ranged from 0.13 to $0.54 \mathrm{mg} / \mathrm{L}$ and averaged $0.30 \mathrm{mg} / \mathrm{L}$. OLS Pond mass loadings of $\mathrm{NH}_{3}$ ranged from 0.14 to $1.65 \mathrm{~kg} / \mathrm{d}$ and averaged $0.68 \mathrm{~kg} / \mathrm{d}$.

\subsubsection{Nitrate $\left(\mathrm{NO}_{3}{ }^{-}\right)$}

Nitrate concentrations and mass loadings are summarized in Table 4.5.2.1 and presented fully in Tables E.4, E.5, E.8, and E.9. Influent nitrate concentrations ranged from 0.01 to 0.22 $\mathrm{mg} / \mathrm{L}$ and averaged $0.10 \mathrm{mg} / \mathrm{L}$. Effluent nitrate concentrations ranged from 0.03 to $0.27 \mathrm{mg} / \mathrm{L}$ 
and averaged $0.18 \mathrm{mg} / \mathrm{L}$. Effluent mass loadings ranged from 0.33 to $2.88 \mathrm{~kg} / \mathrm{d}$ and averaged $1.79 \mathrm{~kg} / \mathrm{d}$. OLS Pond effluent nitrate concentrations ranged from 0.10 to $0.19 \mathrm{mg} / \mathrm{L}$ and averaged $0.16 \mathrm{mg} / \mathrm{L}$. OLS Pond mass loadings of nitrate ranged from 0.06 to $0.57 \mathrm{~kg} / \mathrm{d}$ and averaged $0.34 \mathrm{~kg} / \mathrm{d}$.

\subsubsection{Total Phosphorus (TP)}

Total phosphorus concentrations and mass loadings are summarized in Table 4.5.2.1 and presented fully in Tables E.6 and E.9. Influent total phosphorus concentrations ranged from 0.005 to $0.07 \mathrm{mg} / \mathrm{L}$ and averaged $0.02 \mathrm{mg} / \mathrm{L}$. Effluent total phosphorus concentrations ranged from 0.005 to $0.29 \mathrm{mg} / \mathrm{L}$ and averaged $0.15 \mathrm{mg} / \mathrm{L}$. Effluent mass loadings ranged from 0.01 to $2.76 \mathrm{~kg} / \mathrm{d}$ and averaged $1.35 \mathrm{~kg} / \mathrm{d}$. OLS Pond effluent total phosphorus concentrations ranged from 0005 to $0.10 \mathrm{mg} / \mathrm{L}$ and averaged $0.06 \mathrm{mg} / \mathrm{L}$. OLS Pond mass loadings of total phosphorus ranged from 0.02 to $0.55 \mathrm{~kg} / \mathrm{d}$ and averaged $0.20 \mathrm{~kg} / \mathrm{d}$.

\subsubsection{Nitrite $\left(\mathrm{NO}_{2}{ }^{-}\right)$}

All influent and effluent grab samples had nitrite concentrations less than the MDL. The resulting mass loadings ranged from 0.05 to $0.16 \mathrm{~kg} / \mathrm{d}$ and averaged $0.10 \mathrm{~kg} / \mathrm{d}$. OLS Pond effluent mass loadings ranged from 0.003 to $0.03 \mathrm{~kg} / \mathrm{d}$ and averaged $0.02 \mathrm{~kg} / \mathrm{d}$. These results are presented fully in Table E.5 and E.9.

\subsubsection{Statistical Analysis}

The Paired t-Test and Wilcoxon Signed Rank Test was used to determine if any significance difference existed between influent and effluent monitored parameters. The Paired $t$-Test was used when observed treatment effects were normally distributed, while the Wilcoxon Signed Rank Test was employed with non-normal distribution. The Summaries of the statistical analysis results are presented in Table 4.5.3.1. and 4.5.3.2. 
Table 4.5.3.1 Facility E Effluent Water Quality Monitoring Statistical Analysis Results.

\begin{tabular}{lcccc}
\hline \multicolumn{1}{c}{ Parameter } & $\begin{array}{c}\text { Normality Test } \\
\text { Passed? (Y/N) }\end{array}$ & Test Used & P & $\begin{array}{c}\text { Statistically } \\
\text { Significant } \\
\text { Difference? (Y/N; } \\
\mathbf{P}<\mathbf{0 . 0 5})\end{array}$ \\
\hline $\mathrm{pH}$ & $\mathrm{Y}$ & Paired $t$-Test & $<0.001$ & $\mathrm{Y}$ \\
Temperature & $\mathrm{Y}$ & Paired $t$-Test & 0.279 & $\mathrm{~N}$ \\
Dissolved Oxygen & $\mathrm{Y}$ & Paired $t$-Test & 0.001 & $\mathrm{Y}$ \\
Spc. Cond. & $\mathrm{N}$ & Wilcoxon Signed & 0.016 & $\mathrm{Y}$ \\
Turbidity & $\mathrm{Y}$ & Rank Test & $\mathrm{N}$ \\
TSS & $\mathrm{Y}$ & Paired $t$-Test & 0.087 & $\mathrm{Y}$ \\
Ammonia & $\mathrm{Y}$ & Paired $t$-Test & $<0.001$ & $\mathrm{Y}$ \\
Nitrate & $\mathrm{Y}$ & Paired $t$-Test & 0.001 & $\mathrm{Y}$ \\
Total P & $\mathrm{Y}$ & Paired $t$-Test & 0.015 & $\mathrm{Y}$ \\
BOD 5 & $\mathrm{Y}$ & Paired $t$-Test & $<0.004$ & $\mathrm{Y}$ \\
Nitrite & $\mathrm{N}$ & Wilcoxon Signed & 1.000 & $\mathrm{~N}$ \\
\hline
\end{tabular}

Table 4.5.3.2 Facility E OLS Pond Effluent Water Quality Monitoring Statistical Analysis Results.

\begin{tabular}{|c|c|c|c|c|}
\hline Parameter & $\begin{array}{l}\text { Normality Test } \\
\text { Passed? (Y/N) }\end{array}$ & Test Used & $\mathbf{P}$ & $\begin{array}{c}\text { Statistically } \\
\text { Significant } \\
\text { Difference? (Y/N; } \\
\mathbf{P}<\mathbf{0 . 0 5 )}\end{array}$ \\
\hline $\mathrm{pH}$ & $\mathrm{Y}$ & Paired $t$-Test & $<0.001$ & $\mathrm{Y}$ \\
\hline Temperature & $\mathrm{Y}$ & Paired $t$-Test & 0.082 & $\mathrm{~N}$ \\
\hline Dissolved Oxygen & Y & Paired $t$-Test & $<0.001$ & $\mathrm{Y}$ \\
\hline Spc. Cond. & $\mathrm{N}$ & Paired $t$-Test & 0.55 & $\mathrm{~N}$ \\
\hline Turbidity & $\mathrm{Y}$ & Paired $t$-Test & 0.287 & $\mathrm{~N}$ \\
\hline TSS & $\mathrm{Y}$ & Paired $t$-Test & 0.006 & $\mathrm{Y}$ \\
\hline Ammonia & $\mathrm{N}$ & $\begin{array}{l}\text { Wilcoxon Signed } \\
\text { Rank Test }\end{array}$ & 0.195 & $\mathrm{~N}$ \\
\hline Nitrate & $\mathrm{Y}$ & Paired $t$-Test & 0.083 & $\mathrm{~N}$ \\
\hline Total P & $\mathrm{Y}$ & Paired $t$-Test & 0.003 & $\mathrm{Y}$ \\
\hline $\mathrm{BOD}_{5}$ & $\mathrm{~N}$ & $\begin{array}{l}\text { Wilcoxon Signed } \\
\text { Rank Test }\end{array}$ & 1.000 & $\mathrm{~N}$ \\
\hline Nitrite & $\mathrm{N}$ & $\begin{array}{c}\text { Wilcoxon Signed } \\
\text { Rank Test }\end{array}$ & 1.000 & $\mathrm{~N}$ \\
\hline
\end{tabular}




\subsection{Facility $F$}

\subsubsection{Field Monitoring}

Field monitoring results for Facility F from January 2001 to June 2002 are presented in Table 4.6.1.1. Averages and ranges of concentrations are presented to show extremes due to seasonal variations and impacts of production activities.

Table 4.6.1.1. Field Monitoring Results of Facility F.

\begin{tabular}{cccccc}
\hline Site & $\begin{array}{c}\mathbf{p H}, \text { Std. Units } \\
\text { average } \\
\text { [range] }\end{array}$ & $\begin{array}{c}\text { Temperature, }{ }^{\circ} \mathbf{C} \\
\text { average } \\
\text { [range] }\end{array}$ & $\begin{array}{c}\text { Spc. Cond., } \mu \mathbf{S} / \mathbf{c m} \\
\text { average } \\
\text { [range] }\end{array}$ & $\begin{array}{c}\text { DO, } \mathbf{~ m g} / \mathbf{L} \\
\text { average } \\
\text { [range] }\end{array}$ & $\begin{array}{c}\text { Turbidity, NTU } \\
\text { average } \\
\text { [range] }\end{array}$ \\
\hline \multirow{3}{*}{ Influent } & 7.47 & 12.8 & 524.4 & 9.93 & 1.80 \\
& {$[7.13-7.82]$} & {$[12.1-13.1]$} & {$[500.0-539.0]$} & {$[8.19-11.32]$} & {$[0.62-3.13]$} \\
\multirow{2}{*}{ Effluent } & 7.35 & 12.9 & & & \\
& {$[7.09-7.56]$} & {$[12.0-13.6]$} & {$[500.0-565.9]$} & {$[6.98-9.52]$} & {$[1.00-6.62]$} \\
\hline
\end{tabular}

\subsubsection{Flow}

Measured flow rates, presented fully in Table F.1, ranged from 3,036 to $11,571 \mathrm{~m}^{3} /$ day and averaged $6,387 \mathrm{~m}^{3} /$ day $(557,2,123$, and $1,172 \mathrm{GPM})$.

4.6.1.2 $\mathrm{pH}$

Measured $\mathrm{pH}$ values are summarized in Table 4.6.1.1 and presented fully in Table F.1. Influent $\mathrm{pH}$ values ranged from 7.13 to 7.82 standard units and averaged 7.47. Effluent $\mathrm{pH}$ values ranged from 7.09 to 7.56 and averaged 7.35 .

\subsubsection{Specific Conductance}

Specific conductance values summarized in Table 4.6.1.1 are presented fully in Table F.2. Influent specific conductance values ranged from 500.0 to $539.0 \mu \mathrm{S} / \mathrm{cm}$ and averaged $524.4 \mu \mathrm{S} / \mathrm{cm}$. Effluent specific conductance values ranged from 500.0 to $565.9 \mu \mathrm{S} / \mathrm{cm}$ and averaged $535.8 \mu \mathrm{S} / \mathrm{cm}$. 


\subsubsection{Temperature}

Temperature values, summarized in Table 4.6.1.1, are presented fully in Table F.1. Influent temperatures ranged from 12.1 to $13.1{ }^{\circ} \mathrm{C}\left(53.8\right.$ to $\left.55.6{ }^{\circ} \mathrm{F}\right)$ and averaged $12.8{ }^{\circ} \mathrm{C}(55.0$ $\left.{ }^{\circ} \mathrm{F}\right)$. Effluent temperatures ranged from 12.0 to $13.6{ }^{\circ} \mathrm{C}\left(53.6\right.$ to $\left.56.5{ }^{\circ} \mathrm{F}\right)$ and averaged $12.9{ }^{\circ} \mathrm{C}$ $\left(55.2^{\circ} \mathrm{F}\right)$. Monitored temperatures were in acceptable ranges for the survival of rainbow trout (Meade, 1989).

\subsubsection{Dissolved Oxygen}

Dissolved oxygen concentrations summarized in Table 4.6.1.1, are presented fully in Table F.2. Typically, DO concentrations remained relatively constant in the facility's influent, ranging from 8.19 to $11.32 \mathrm{mg} / \mathrm{L}$, with an average of $9.93 \mathrm{mg} / \mathrm{L}$, and were within the acceptable range for salmonid production (5 mg/L to saturation; Heinen 1996). Effluent DO concentrations ranged from 6.98 to $9.52 \mathrm{mg} / \mathrm{L}$ and average $8.25 \mathrm{mg} / \mathrm{L}$.

\subsubsection{Turbidity}

Turbidity values are summarized in Table 4.6.1.1 and presented fully in Table F.2. Influent turbidity ranged from 0.62 to $3.13 \mathrm{NTU}$ and averaged $1.80 \mathrm{NTU}$. Effluent turbidity ranged from 1.00 to $6.62 \mathrm{NTU}$ and averaged $3.11 \mathrm{NTU}$.

\subsubsection{Grab Samples}

Grab sample results from January 2001 to June 2002 are summarized in Table 4.6.2.1 and presented fully in Tables F.3 to F.6. Averages and ranges of concentration and loading are presented to show extremes due to seasonal variations and impacts of production activities. 
Table 4.6.2.1 Grab Sample Results of Facility F.

\begin{tabular}{|c|c|c|c|c|c|}
\hline Site & $\begin{array}{c}\text { TSS } \\
\text { average } \\
\text { [range] }\end{array}$ & $\begin{array}{c}\text { BOD }_{5} \\
\text { average } \\
\text { [range] }\end{array}$ & $\begin{array}{c}\mathrm{NH}_{3} \\
\text { average } \\
\text { [range] }\end{array}$ & $\begin{array}{c}\mathrm{NO}_{3}^{-} \\
\text {average } \\
\text { [range] }\end{array}$ & $\begin{array}{c}\text { TP } \\
\text { average } \\
\text { [range] }\end{array}$ \\
\hline $\begin{array}{l}\text { Influent } \\
\text { concentration, } \\
\mathrm{mg} / \mathrm{L}\end{array}$ & $\begin{array}{c}2.36 \\
{[1.00-3.00]}\end{array}$ & $\begin{array}{c}1.43^{\dagger} \\
{\left[1.43^{\dagger}\right]}\end{array}$ & $\begin{array}{c}0.03^{\dagger} \\
{\left[0.01^{\dagger}-0.06\right]}\end{array}$ & $\begin{array}{c}0.15 \\
{[0.08-0.24]}\end{array}$ & $\begin{array}{c}0.02^{\dagger} \\
{\left[0.005^{\dagger}-0.07\right]}\end{array}$ \\
\hline $\begin{array}{l}\text { Effluent } \\
\text { concentration, } \\
\mathrm{mg} / \mathrm{L}\end{array}$ & $\begin{array}{c}6.43 \\
{[3.00-10.0]}\end{array}$ & $\begin{array}{c}2.75^{\dagger} \\
{\left[1.43^{\dagger}-5.60\right]}\end{array}$ & $\begin{array}{c}0.36 \\
{[0.13-0.65]}\end{array}$ & $\begin{array}{c}0.18 \\
{[0.11-0.29]}\end{array}$ & $\begin{array}{c}0.10 \\
{\left[0.005^{\dagger}-0.19\right]}\end{array}$ \\
\hline $\begin{array}{l}\text { Effluent loading, } \\
\mathrm{kg} / \mathrm{d}\end{array}$ & $\begin{array}{c}37.4 \\
{[17.0-57.9]}\end{array}$ & $\begin{array}{c}18.6^{\dagger} \\
{\left[4.34^{\dagger}-46.3\right]}\end{array}$ & $\begin{array}{c}2.15 \\
{[0.65-3.57]}\end{array}$ & $\begin{array}{c}1.20 \\
{[0.53-2.48]}\end{array}$ & $\begin{array}{c}0.62^{\dagger} \\
{[0.003-1.52]}\end{array}$ \\
\hline
\end{tabular}

$\dagger$ Presented valued was calculated by: $\frac{\mathrm{MDL}}{2}$.

\subsubsection{Total Suspended Solids (TSS)}

TSS concentrations are summarized in Table 4.6.2.1 and presented fully in Table F.3. Influent TSS concentrations ranged from 1.00 to $3.00 \mathrm{mg} / \mathrm{L}$ and averaged $2.36 \mathrm{mg} / \mathrm{L}$. Effluent TSS concentrations ranged from 3.00 to $10.0 \mathrm{mg} / \mathrm{L}$ and averaged $6.43 \mathrm{mg} / \mathrm{L}$. TSS loadings ranged from 17.0 to $57.9 \mathrm{~kg} / \mathrm{d}$ and averaged $37.4 \mathrm{~kg} /$ day.

\subsubsection{Five Day Biochemical Oxygen Demand $\left(B O D_{5}\right)$}

All influent grab samples analyzed for $\mathrm{BOD}_{5}$ were below the MDL. Effluent $\mathrm{BOD}_{5}$ concentrations ranged from 1.43 to $5.60 \mathrm{mg} / \mathrm{L}$ and averaged $2.75 \mathrm{mg} / \mathrm{L}$. Mass loadings of $\mathrm{BOD}_{5}$ ranged from 4.34 to $46.3 \mathrm{~kg} / \mathrm{d}$ and averaged $18.6 \mathrm{~kg} / \mathrm{d}$. Results are summarized in Table 4.6.2.1 and presented fully in Table F.6.

\subsubsection{Total Ammonia Nitrogen (TAN)}

Ammonia concentrations and mass loadings are summarized in Table 4.6.2.1 and presented fully in Tables F.3 and F.4. Influent $\mathrm{NH}_{3}$ concentrations ranged from 0.01 to 0.06 
$\mathrm{mg} / \mathrm{L}$ and averaged $0.03 \mathrm{mg} / \mathrm{L}$. Effluent $\mathrm{NH}_{3}$ concentrations ranged from 0.10 to $0.59 \mathrm{mg} / \mathrm{L}$ and averaged $0.36 \mathrm{mg} / \mathrm{L}$. Effluent mass loadings ranged from 0.65 to $3.57 \mathrm{~kg} / \mathrm{d}$ and averaged 2.15 $\mathrm{kg} / \mathrm{d}$.

\subsubsection{Nitrate $\left(\mathrm{NO}_{3}{ }^{-}\right)$}

Nitrate concentrations and mass loadings are summarized in Table 4.6.2.1 and presented fully in Tables F.4 and F.5. Influent nitrate concentrations ranged from 0.08 to $0.24 \mathrm{mg} / \mathrm{L}$ and averaged $0.15 \mathrm{mg} / \mathrm{L}$. Effluent nitrate concentrations ranged from 0.11 to $0.29 \mathrm{mg} / \mathrm{L}$ and averaged $0.18 \mathrm{mg} / \mathrm{L}$. Effluent mass loadings ranged from 0.53 to $2.48 \mathrm{~kg} / \mathrm{d}$ and averaged 1.20 $\mathrm{kg} / \mathrm{d}$.

\subsubsection{Total Phosphorus (TP)}

Total phosphorus concentrations and mass loadings are summarized in Table 4.6.2.1 and presented fully in Table F.6. Influent total phosphorus concentrations ranged from 0.005 to 0.07 $\mathrm{mg} / \mathrm{L}$ and averaged $0.02 \mathrm{mg} / \mathrm{L}$. Effluent total phosphorus concentrations ranged from 0.005 to $0.19 \mathrm{mg} / \mathrm{L}$ and averaged $0.10 \mathrm{mg} / \mathrm{L}$. Effluent mass loadings ranged from 0.003 to $1.52 \mathrm{~kg} / \mathrm{d}$ and averaged $0.62 \mathrm{~kg} / \mathrm{d}$.

\subsubsection{Nitrite $\left(\mathrm{NO}_{2}^{-}\right)$}

All influent and effluent grab samples had nitrite concentrations less than the MDL. The resulting mass loadings ranged from 0.03 to $0.12 \mathrm{~kg} / \mathrm{d}$ and averaged $0.06 \mathrm{~kg} / \mathrm{d}$. These results are presented fully in Table F.5.

\subsubsection{Statistical Analysis}

The Paired t-Test and Wilcoxon Signed Rank Test was used to determine if any significance difference existed between influent and effluent monitored parameters. The Paired $t$-Test was used when observed treatment effects were normally distributed, while the Wilcoxon 
Signed Rank Test was employed with non-normal distribution. The Summaries of the statistical analysis results are presented in Table 4.6.3.1.

Table 4.6.3.1 Facility F Water Quality Monitoring Statistical Analysis Results.

\begin{tabular}{lcccc}
\hline \multicolumn{1}{c}{ Parameter } & $\begin{array}{c}\text { Normality Test } \\
\text { Passed? (Y/N) }\end{array}$ & Test Used & P & $\begin{array}{c}\text { Statistically } \\
\text { Significant } \\
\text { Difference? (Y/N; } \\
\mathbf{P}<\mathbf{0 . 0 5})\end{array}$ \\
\hline $\mathrm{pH}$ & $\mathrm{Y}$ & Paired $t$-Test & 0.018 & $\mathrm{Y}$ \\
Temperature & $\mathrm{Y}$ & Paired $t$-Test & 0.747 & $\mathrm{~N}$ \\
Dissolved Oxygen & $\mathrm{Y}$ & Paired $t$-Test & 0.047 & $\mathrm{Y}$ \\
Spc. Cond. & $\mathrm{Y}$ & Paired $t$-Test & 0.096 & $\mathrm{~N}$ \\
Turbidity & $\mathrm{Y}$ & Paired $t$-Test & 0.044 & $\mathrm{Y}$ \\
TSS & $\mathrm{Y}$ & Paired $t$-Test & 0.007 & $\mathrm{Y}$ \\
Ammonia & $\mathrm{Y}$ & Paired $t$-Test & 0.004 & $\mathrm{Y}$ \\
Nitrate & $\mathrm{N}$ & Paired $t$-Test & 0.084 & $\mathrm{~N}$ \\
Total P & $\mathrm{Y}$ & Paired $t$-Test & 0.002 & $\mathrm{Y}$ \\
BOD $\mathrm{S}_{5}$ & $\mathrm{Y}$ & Paired $t$-Test & 0.091 & $\mathrm{~N}$ \\
Nitrite & $\mathrm{N}$ & Wilcoxon Signed & 1.000 & $\mathrm{~N}$ \\
\hline
\end{tabular}

\section{CHAPTER 5. DISCUSSION}

\subsection{Field Measurements}

Presented in Table 5.1 are the average changes in field monitoring results from influent and effluent for all facilities. In general, small increases in water temperature, turbidity, and specific conductance were observed and attributed to atmospheric exposure and the addition of fish production waste. Reductions in DO were attributed to fish respiration and the biological decomposition of fish biosolids. 
Table 5.1 Average change in measured parameters from influent to effluent.

\begin{tabular}{cccccc}
\hline Facility & Temperature, ${ }^{\circ} \mathrm{C}$ & $\mathrm{pH}$, Std. Units & DO, mg/L & Turbidity, NTU & $\begin{array}{c}\text { Specific } \\
\text { Conductance, } \\
\mu \mathrm{S} / \mathrm{cm}\end{array}$ \\
\hline A & 0.86 & -0.09 & $-1.91^{\dagger}$ & $2.60^{\dagger}$ & $9.29^{\dagger}$ \\
B & 2.00 & 0.07 & 0.90 & 0.13 & 12.2 \\
C & 0.79 & 0.22 & 0.99 & $4.17^{\dagger}$ & 3.68 \\
D & $0.90^{\dagger}$ & 0.12 & $-1.26^{\dagger}$ & $1.17^{\dagger}$ & $22.24^{\dagger}$ \\
E (Outlet) & 0.18 & $0.53^{\dagger}$ & $1.52^{\dagger}$ & 1.09 & $32.30^{\dagger}$ \\
E (OLS Pond) & 1.13 & $0.51^{\dagger}$ & $3.08^{\dagger}$ & 0.50 & 40.23 \\
F & 0.05 & $-0.12^{\dagger}$ & $-1.68^{\dagger}$ & $1.31^{\dagger}$ & 11.40 \\
\hline
\end{tabular}

$\dagger$ : Indicates a statistically significant change.

\section{$5.1 .1 \mathrm{pH}$}

Measurements of $\mathrm{pH}$ were relatively constant from influent to effluent for facilities $\mathrm{A}, \mathrm{B}$, C, D and not statistically different. Facilities $\mathrm{E}$ and $\mathrm{F}$ both had statistically significant increases in $\mathrm{pH}$ from influent to effluent as a result of the $\mathrm{CO}_{2}$ stripping. Equations 5.1.1 and 5.1.2 represent the equilibrium relationships between $\mathrm{CO}_{2(\mathrm{~g})}, \mathrm{CO}_{2(\mathrm{aq})}, \mathrm{H}_{2} \mathrm{O}, \mathrm{H}_{2} \mathrm{CO}_{3}$ (carbonic acid), $\mathrm{H}^{+}$ (pH), $\mathrm{HCO}_{3}^{-}$(carbonate), and $\mathrm{CO}_{3}^{-2}$ (carbonate) (Snoeyink and Jenkins, 1980).

$$
\begin{aligned}
& \mathrm{CO}_{2(\mathrm{~g})} \leftrightarrow \mathrm{CO}_{2(\mathrm{aq})} ; \mathrm{K}_{\mathrm{H}}=10^{-1.5} \\
& \mathrm{CO}_{2(\mathrm{aq})}+\mathrm{H}_{2} \mathrm{O} \rightarrow \mathrm{H}_{2} \mathrm{CO}_{3} \leftrightarrow \mathrm{H}^{+}+\mathrm{HCO}_{3}^{-} \leftrightarrow \mathrm{H}^{+}+\mathrm{CO}_{3}^{-2}
\end{aligned}
$$

When $\mathrm{CO}_{2}$ is removed from the systems with the use of packed aeration columns (PAC), the concentration of $\mathrm{H}^{+}$is reduced; this results in an increase in $\mathrm{pH}$.

Average effluent $\mathrm{pH}$ values of all facilities were with the regulated range of $6-9$ standard units. Presented in Figure 5.1.1.1 is the average effluent $\mathrm{pH}$ for each facility and the permitted limitations. 


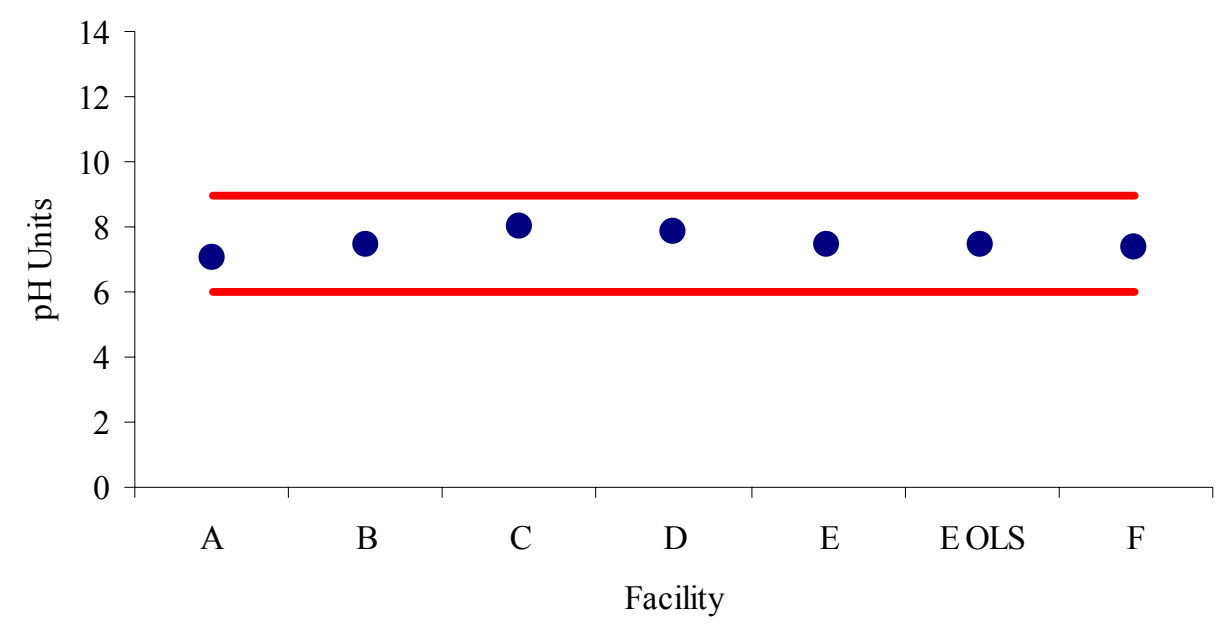

Figure 5.1.1.1 Average effluent $\mathrm{pH}$ of each facility and permit limitations.

\subsubsection{Dissolved Oxygen}

Three facilities had slight reductions in DO concentration from influent to effluent while the other three had slight increases in DO concentration. DO concentration reductions in facilities $\mathrm{A}, \mathrm{D}$, and $\mathrm{E}$ were attributed to fish metabolic requirements and the biological decomposition of organic matter in fish production waste (Hinshaw, 2002). Presented in Figures 5.1.2.1, 5.1.2.2, and 5.1.2.3 are plots of influent and effluent DO concentrations of facilities A, $\mathrm{D}$, and $\mathrm{E}$ over the study period.

\section{Facility A}

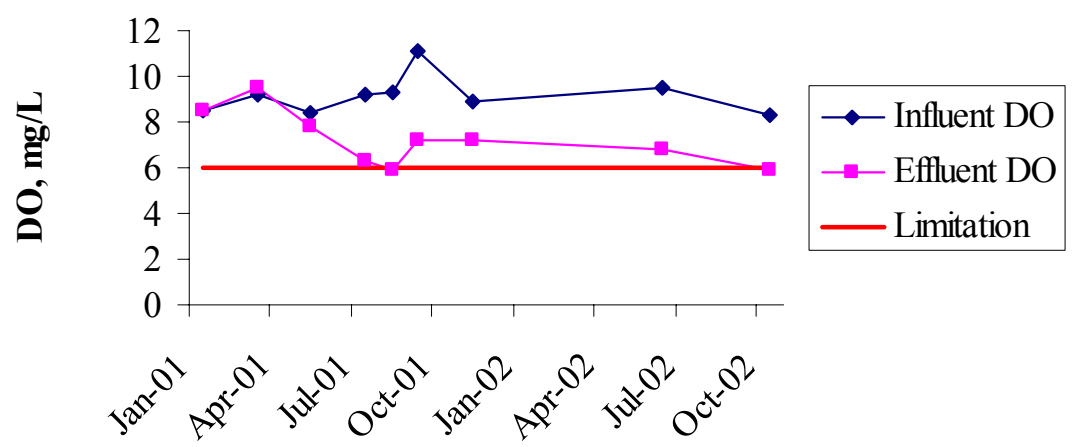

Figure 5.1.2.1. Influent and Effluent DO Concentrations of Facility A. 


\section{Facility D}

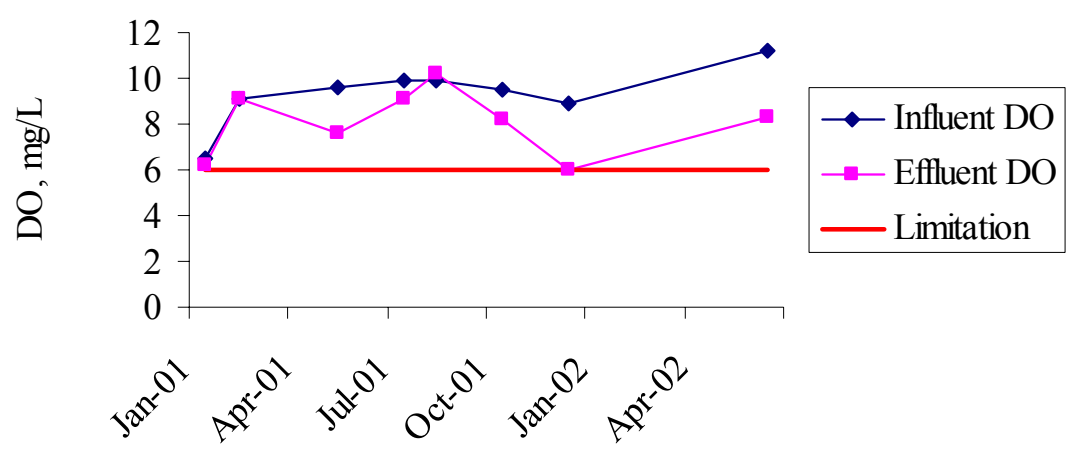

Figure 5.1.2.2. Influent and Effluent DO Concentrations of Facility D.

Facility E

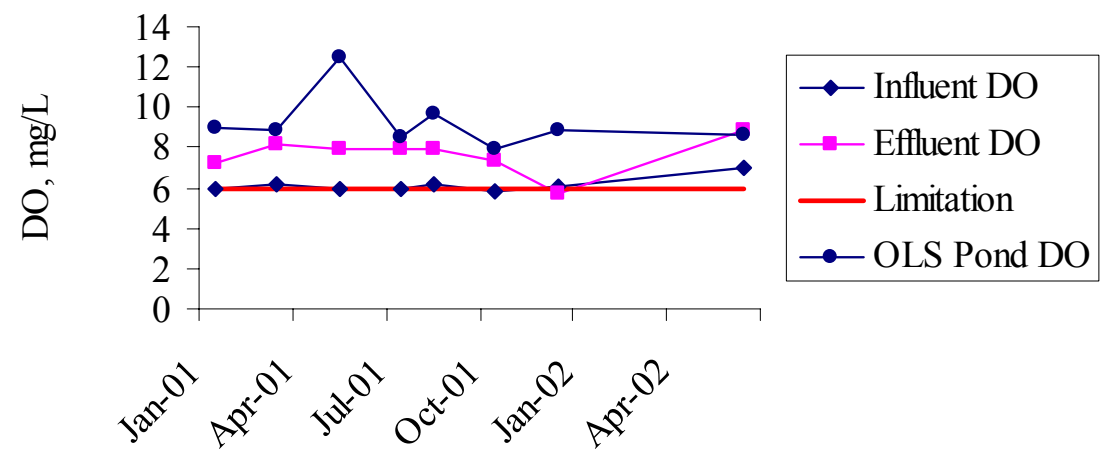

Figure 5.1.2.3. Influent and Effluent DO Concentrations of Facility E.

Facilities A, D, and E each had one occurrence of effluent DO below the regulated limit of $6 \mathrm{mg} / \mathrm{L}$; however, average concentrations of all facilities were within the acceptable range. The low DO measurements of facility A effluent was most likely the result of the aerobic biological decomposition of organic waste in the sedimentation pond. Equations 5.1.2.2, 5.1.2.3, and 5.1.2.4 represent three primary biologically mediated reactions that can reduce dissolved oxygen concentrations in water. COHNS represents carbon, oxygen, hydrogen, nitrogen, and sulfur of the organic material and $\mathrm{C}_{5} \mathrm{H}_{7} \mathrm{NO}_{2}$ represents cell tissue (Metcalf \& Eddy, 2003). 


\section{Oxidation:}

$\mathrm{COHNS}+\mathrm{O}_{2}+$ bacteria $\rightarrow \mathrm{CO}_{2}+\mathrm{H}_{2} \mathrm{O}+\mathrm{NH}_{3}+$ energy

(EQN 5.1.2.2)

Synthesis:

$\mathrm{COHNS}+\mathrm{O}_{2}+$ bacteria + energy $\underset{\text { New cell tissue }}{\rightarrow} \mathrm{C}_{5} \mathrm{H}_{7} \mathrm{NO}_{2}$

(EQN 5.1.2.3)

Endogenous respiration:

$\mathrm{C}_{5} \mathrm{H}_{7} \mathrm{NO}_{2}+5 \mathrm{O}_{2} \rightarrow 5 \mathrm{CO}_{2}+\mathrm{NH}_{3}+2 \mathrm{H}_{2} \mathrm{O}$

(EQN 5.1.2.4)

DO depression at facility $\mathrm{D}$ were the result of two main problems, oxygen consumption through biological decomposition of organic material (see equations 5.1.2.2, 5.1.2.3, and 5.1.2.4) and low reaeration efficiency between raceways. Lack of effective solids removal led to solids accumulation in the earthen raceways and subsequent decomposition. Aeration in facility D was accomplished through the intermittent use of floating surface aerators and simple weir cascade aeration between containment areas. Low DO levels were most likely due to an inadequate number of mechanical aerators and the low reaeration efficiencies of simple weirs. Soderberg (1995) reported simple weir reaeration efficiencies of 6.2, 9.3, and 12.4\% for head losses of 22.9, 30.5, and $61.0 \mathrm{~cm}$, respectively. All the simple weir head losses at facility D were less than $61.0 \mathrm{~cm}$.

Low DO concentrations in the effluent of facility E were most likely a result of high fish density and thus high $\mathrm{O}_{2}$ consumption in a containment area located immediately before discharge to the receiving stream. Market-size fish were held in the containment area for shipment to the processing facility

Increases in $\mathrm{DO}$ concentration in facilities $\mathrm{B}, \mathrm{C}$, and $\mathrm{E}$ were attributed to efficient reaeration in combination with low fish demand, photosynthetic activity of aquatic plants, and liquid oxygen supplementation. Equation 5.1.2.1 represents the formula for photosynthesis by 
green plants, bryophytes, and algae that results in $\mathrm{O}_{2}$ production (Smith, 1996). Photosynthesis involves the reduction of six moles of $\mathrm{CO}_{2}$ to one mole of sugar $\left(\mathrm{CH}_{2} \mathrm{O}\right)$ and results in the removal of six moles of $\mathrm{H}_{2} \mathrm{O}$ and the production of six moles of $\mathrm{O}_{2}$.

$$
6 \mathrm{CO}_{2}+6 \mathrm{H}_{2} \mathrm{O} \rightarrow 6 \mathrm{CO}_{2}+12 \mathrm{H}^{+}+6 \mathrm{O} \rightarrow\left(\mathrm{CH}_{2} \mathrm{O}\right)_{6}+6 \mathrm{O}_{2}
$$

Presented in Figures 5.1.2.4, 5.1.2.5, and 5.1.2.6 are the influent and effluent DO concentrations of facilities B, C, and F over the study period.

Facility B

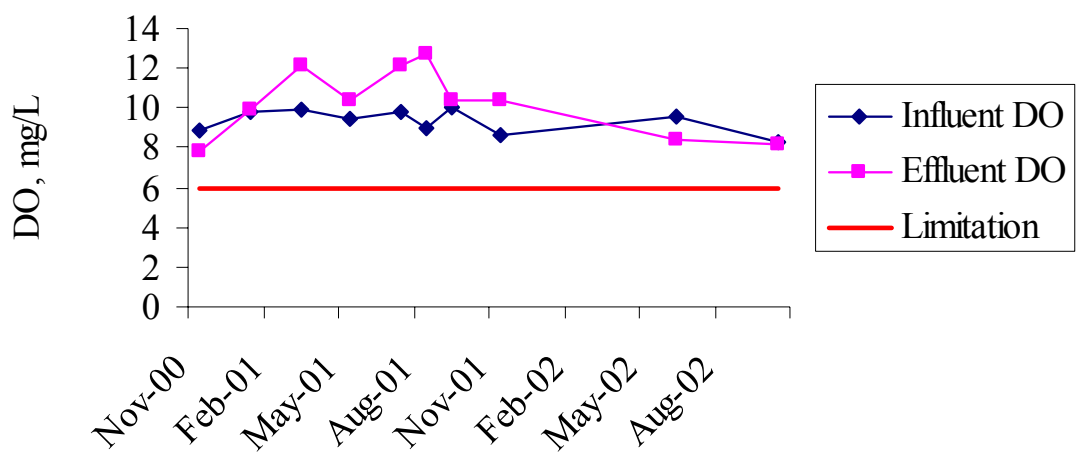

Figure 5.1.2.4. Influent and Effluent DO Concentrations of Facility B.

Facility C

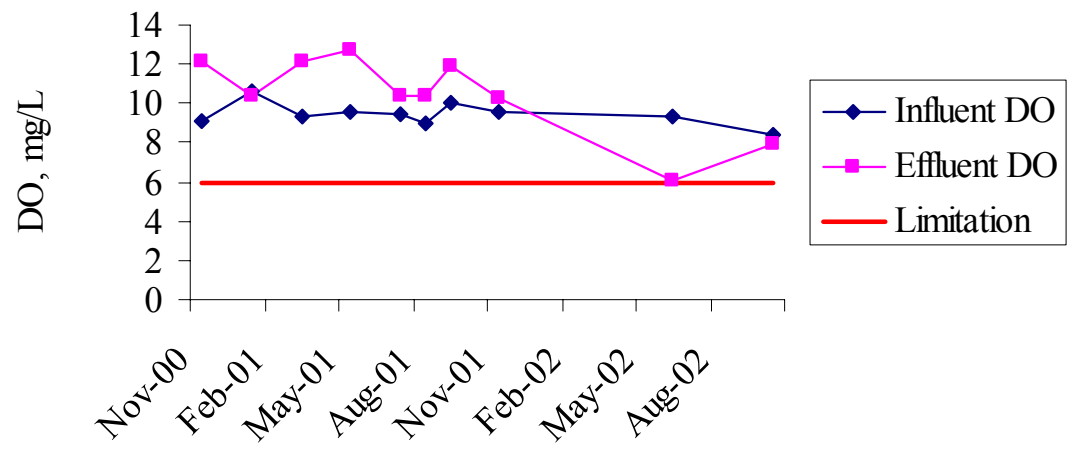

Figure 5.1.2.5. Influent and Effluent DO Concentrations of Facility $C$. 
Facility F

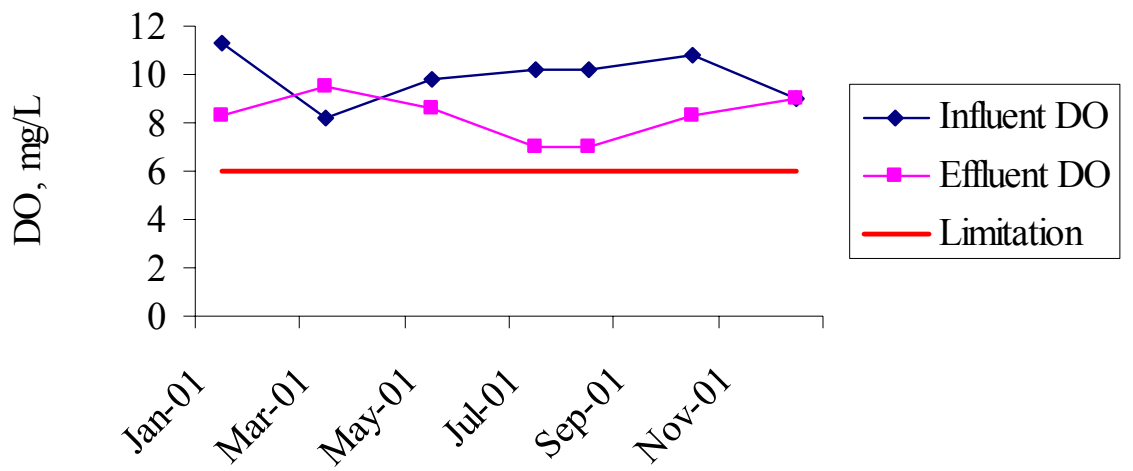

Figure 5.1.2.6. Influent and Effluent DO Concentrations of Facility F.

\subsection{Grab Samples}

Presented in Table 5.2.1 are the normal ranges of pollutant concentration increase reported by four studies as reported by Hinshaw (2002). In general, small increases in pollutant concentrations were observed in the process water from influent to effluent as a result of production activities. Concentrations of measured pollutants were within acceptable ranges of anticipated limits for all facilities and compared relatively well to reported data.

Table 5.2.1 Normal ranges of pollutant concentration increase reported by Hinshaw, 2002.

\begin{tabular}{cccccc}
\hline Study No. & $\mathrm{TSS}, \mathrm{mg} / \mathrm{L}$ & $\mathrm{BOD}_{5}, \mathrm{mg} / \mathrm{L}$ & $\mathrm{TAN}, \mathrm{mg} / \mathrm{L}$ & $\mathrm{NO}_{3}{ }^{-}, \mathrm{mg} / \mathrm{L}$ & $\mathrm{TP}, \mathrm{mg} / \mathrm{L}$ \\
\hline 1 & $0-55$ & 5.36 & 0.53 & 1.68 & $*$ \\
2 & 3.7 & 4.0 & 0.49 & $0-0.17$ & $*$ \\
3 & $0-2.8$ & 0 & $0.01-0.18$ & $0-0.017$ & $0-0.13$ \\
4 & 4.36 & 1.5 & 0.172 & 0.036 & 0.038 \\
\hline
\end{tabular}

* No data reported in study. 
Table 5.2.2 Average Changes in Pollutant Concentrations and Mass Loading from Influent to Effluent for All Participating Facilities.

\begin{tabular}{lccccc}
\hline Facility & $\begin{array}{c}\mathrm{TSS}, \mathrm{mg} / \mathrm{L} \\
(\mathrm{kg} / \mathrm{day})\end{array}$ & $\begin{array}{c}\mathrm{BOD}_{5}, \mathrm{mg} / \mathrm{L} \\
(\mathrm{kg} / \text { day })\end{array}$ & $\begin{array}{c}\mathrm{TAN}, \mathrm{mg} / \mathrm{L} \\
(\mathrm{kg} / \mathrm{day})\end{array}$ & $\begin{array}{c}\mathrm{NO}_{3}{ }^{-}, \mathrm{mg} / \mathrm{L} \\
(\mathrm{kg} / \text { day })\end{array}$ & $\begin{array}{c}\mathrm{TP}, \mathrm{mg} / \mathrm{L} \\
(\mathrm{kg} / \text { day })\end{array}$ \\
\hline $\mathrm{A}$ & $5.74^{\dagger}$ & $3.27^{\dagger}$ & $0.24^{\dagger}$ & $0.52^{\dagger}$ & $0.49^{\dagger}$ \\
& $(44.2)$ & $(24.4)$ & $(1.55)$ & $(3.02)$ & $(3.52)$ \\
$\mathrm{B}$ & $1.85^{\dagger}$ & 0.00 & $0.03^{\dagger}$ & 0.03 & $0.01^{\dagger}$ \\
& $(8.20)$ & $(0.00)$ & $(0.13)$ & $(0.32)$ & $(0.06)$ \\
$\mathrm{C}$ & $4.22^{\dagger}$ & 0.28 & $0.12^{\dagger}$ & $-0.07^{\mathrm{A}}$ & $0.04^{\dagger}$ \\
& $(7.70)$ & $(0.46)$ & $(0.21)$ & $(-0.10)$ & $(0.06)$ \\
$\mathrm{D}$ & $7.88^{\dagger}$ & 0.99 & $0.18^{\dagger}$ & 0.00 & $0.17^{\dagger}$ \\
& $(27.3)$ & $(3.00)$ & $(0.35)$ & $(0.00)$ & $(0.42)$ \\
$\mathrm{E}$ (outlet) & $5.52^{\dagger}$ & $2.93^{\dagger}$ & $0.07^{\dagger}$ & $0.08^{\dagger}$ & $0.13^{\dagger}$ \\
& $(58.1)$ & $(32.5)$ & $(0.56)$ & $(0.72)$ & $(1.22)$ \\
$\mathrm{E}$ (OLS Pond) & $3.31^{\dagger}$ & 0.27 & 0.06 & 0.06 & $0.04^{\dagger}$ \\
& $(-10.6)^{\mathrm{B}}$ & $(-10.3)^{\mathrm{B}}$ & $(-1.82)^{\mathrm{B}}$ & $(-0.73)^{\mathrm{B}}$ & $(0.07)^{\mathrm{B}}$ \\
$\mathrm{F}$ & $4.07^{\dagger}$ & 1.32 & $0.33^{\dagger}$ & 0.03 & $0.08^{\dagger}$ \\
& $(23.6)$ & $(9.43)$ & $(1.92)$ & $(0.14)$ & $(0.53)$ \\
\hline
\end{tabular}

A: Overall reduction in concentration and mass load from influent to effluent.

B: Overall reduction in mass load due to partial flow of the facility.

$\dagger$ : Statistically significant change.

Typically, the generation of pollutants correlated with fish production; operations with larger fish production had higher pollutant concentrations and mass loads. The order of fish production, from highest to lowest was A, E, F, C, D, and B, while order of mass load TSS production was E, A, D, F, B, and C. Facility D had the highest average concentration increase in TSS, but this was attributed to the lack of effluent treatment for solids removal and the use of earthen raceways which could contribute solids by stream bank erosion. Additionally, facility D had similar fish production to that of $\mathrm{B}$ and $\mathrm{C}$, but discharged higher concentrations and mass loadings for all monitored parameters.

Facility $\mathrm{C}$ had an average reduction in nitrate concentration from influent to effluent. Nitrate reduction could be contributed to uptake by aquatic plants in the operation's sedimentation pond. Redding et al. (1997) observed decreases in nitrate concentrations in aquaculture wastewaters as it passed through ponds containing aquatic plants. 


\subsubsection{Un-ionized Ammonia Nitrogen}

Ammonia is the primary nitrogenous by-product of fish metabolism and is a concern for aquaculture because it is toxic in its un-ionized form $\left(\mathrm{NH}_{3}\right)$ (Wedenmyer, 2001). In water, ammonia nitrogen exists as either the ammonium $\left(\mathrm{NH}_{4}^{+}\right)$or un-ionized ammonia $\left(\mathrm{NH}_{3}\right)$ ions, and their concentrations are regulated by $\mathrm{pH}$. Equations 5.2.1.1 and 5.2.1.1 present the equilibrium reactions which governs ammonia nitrogen speciation.

$$
\begin{aligned}
& \mathrm{NH}_{3} \leftrightarrow \mathrm{NH}_{4}^{+}, K_{\mathrm{H}}=57 \\
& \mathrm{NH}_{4}^{+} \leftrightarrow \mathrm{NH}_{3}+\mathrm{H}^{+}, K_{\mathrm{a}}=10^{-9.25}
\end{aligned}
$$

Grab sample measurements of TAN include both $\mathrm{NH}_{3}$ and $\mathrm{NH}_{4}^{+}$concentrations and thus, concentration of un-ionized ammonia is not explicitly represented as TAN. However, Soderberg (1995) presented the following equation for un-ionized ammonia nitrogen calculation.

$$
\text { Un-ionized ammonia }\left(\mathrm{NH}_{3}\right) \mathrm{mg} / \mathrm{L}=\frac{\mathrm{TAN}(\mathrm{mg} / \mathrm{L})}{1+10^{(\mathrm{pka}-\mathrm{pH})}}
$$

where,

$$
\begin{gathered}
\text { pka }=\text { negative } \log \text { of the acid dissociation constant. } \\
\text { pka }=0.09018+\frac{2729.92}{\mathrm{~T}+273.15} \\
\text { where, } \\
\qquad \mathrm{T}=\text { temperature in }{ }^{\circ} \mathrm{C} .
\end{gathered}
$$

Presented in Figure 5.2.1.1 is a distribution plot of ammonia $\left(\mathrm{NH}_{3}\right)$ and ammonium $\left(\mathrm{NH}_{4}{ }^{+}\right)$as a function of $\mathrm{pH}$. 


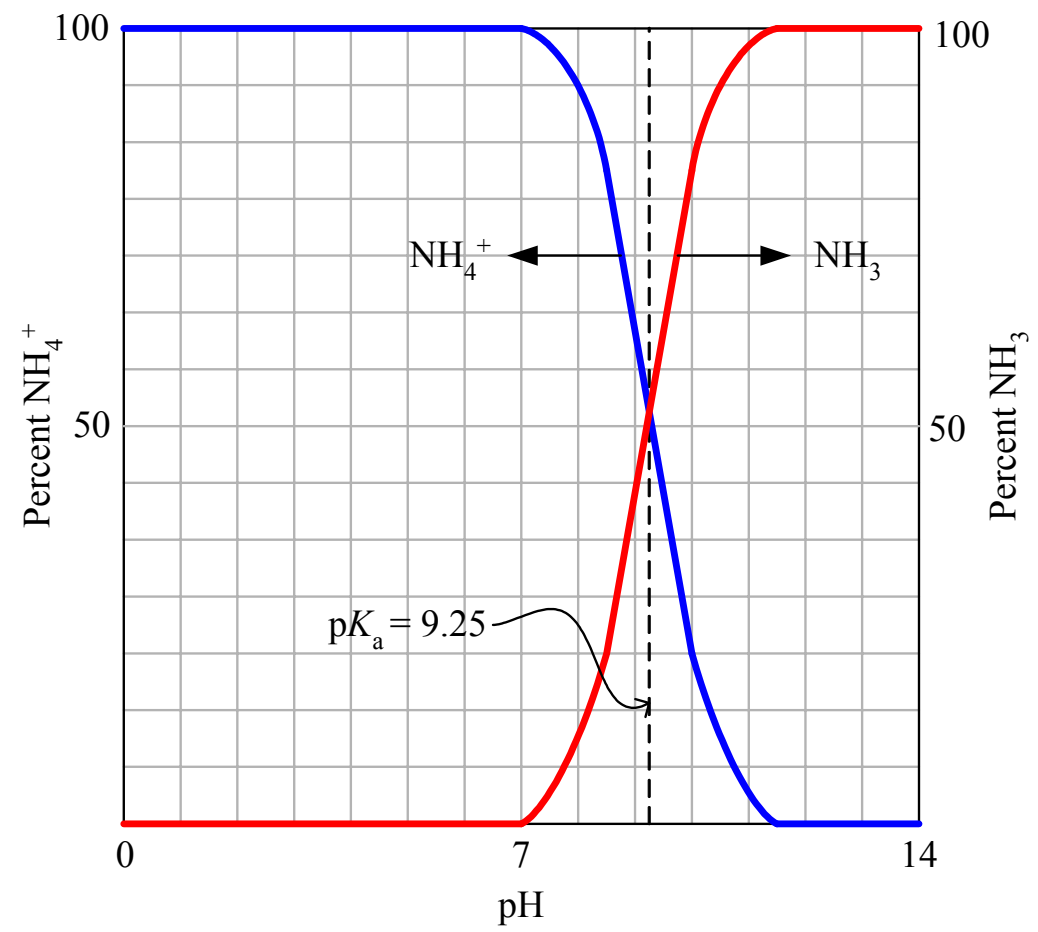

Figure 5.2.1.1 Ammonia Speciation as a Function of pH.

Presented in Table 5.2.1.1 are the calculated un-ionized ammonia concentrations and mass loadings of all participating facilities.

Table 5.2.1.1. Calculated Un-ionized Ammonia Concentrations, Mass Loads, and Production Output of Participating Facilities.

\begin{tabular}{|c|c|c|c|}
\hline Facility & $\begin{array}{l}\text { Average influent un- } \\
\text { ionized ammonia, } \mathrm{mg} / \mathrm{L} \\
\text { (range) }\end{array}$ & $\begin{array}{l}\text { Average effluent un- } \\
\text { ionized ammonia, mg/L } \\
\text { (range) }\end{array}$ & $\begin{array}{c}\text { Average un-ionized } \\
\text { ammonia production } \\
\text { [effluent - influent] } \\
\mathrm{mg} / \mathrm{L} \\
\end{array}$ \\
\hline A & $\begin{array}{c}1.7 \times 10^{-4} \\
\left(2.0 \times 10^{-5}-6.6 \times 10^{-4}\right)\end{array}$ & $\begin{array}{c}9.1 \times 10^{-4} \\
\left(2.8 \times 10^{-4}-3.2410^{-3}\right)\end{array}$ & $7.4 \times 10^{-4}$ \\
\hline B & $\begin{array}{c}4.5 \times 10^{-4} \\
\left(2.0 \times 10^{-5}-2.28 \times 10^{-3}\right)\end{array}$ & $\begin{array}{c}1.08 \times 10^{-3} \\
\left(2.0 \times 10^{-4}-4.47 \times 10^{-3}\right)\end{array}$ & $6.3 \times 10^{-4}$ \\
\hline $\mathrm{C}$ & $\begin{array}{c}1.58 \times 10^{-3} \\
\left(1.3 \times 10^{-4}-8.86 \times 10^{-3}\right)\end{array}$ & $\begin{array}{c}8.01 \times 10^{-3} \\
\left(5.4 \times 10^{-4}-1.893 \times 10^{-2}\right)\end{array}$ & $6.43 \times 10^{-3}$ \\
\hline $\mathrm{D}$ & $\begin{array}{c}5.4 \times 10^{-4} \\
\left(5.0 \times 10^{-5}-2.07 \times 10^{-3}\right)\end{array}$ & $\begin{array}{c}3.41 \times 10^{-3} \\
\left(1.12 \times 10^{-3}-6.74 \times 10^{-3}\right)\end{array}$ & $2.87 \times 10^{-3}$ \\
\hline $\mathrm{E}$ & $\begin{array}{c}2.9 \times 10^{-4} \\
\left(1.0 \times 10^{-4}-6.4 \times 10^{-4}\right)\end{array}$ & $\begin{array}{c}2.54 \times 10^{-3} \\
\left(7.6 \times 10^{-4}-6.26 \times 10^{-3}\right)\end{array}$ & $2.25 \times 10^{-3}$ \\
\hline E (OLS Pond) & $\begin{array}{c}2.9 \times 10^{-4} \\
\left(1.0 \times 10^{-4}-6.4 \times 10^{-4}\right)\end{array}$ & $\begin{array}{c}2.57 \times 10^{-3} \\
\left(4.1 \times 10^{-4}-4.52 \times 10^{-3}\right)\end{array}$ & $2.28 \times 10^{-3}$ \\
\hline $\mathrm{F}$ & $\begin{array}{c}2.4 \times 10^{-4} \\
\left(4.0 \times 10^{-5}-4.9 \times 10^{-4}\right)\end{array}$ & $\begin{array}{c}1.91 \times 10^{-3} \\
\left(4.7 \times 10^{-4}-3.28 \times 10^{-3}\right)\end{array}$ & $1.67 \times 10^{-3}$ \\
\hline
\end{tabular}


The U.S. Environmental Protection Agency has established acceptable concentration of $\mathrm{NH}_{3}$ not to exceed $0.016 \mathrm{mg} / \mathrm{L}$ for aquatic organisms. Reduced growth rates of rainbow trout were reported at $0.0166 \mathrm{mg} / \mathrm{L} \mathrm{NH}_{3}$, but not at $0.0125 \mathrm{mg} / \mathrm{L}$ by Larmoyeaux and Piper (1973). All facility effluents were below the toxic threshold of $0.016 \mathrm{mg} / \mathrm{L}$ and thus could be further utilized for production.

\subsection{Pollutant Spikes}

Due to the long distance between the WVU campus and the study sites, it was difficult to plan sampling events to coincide with plant activities that could influence effluent water quality such as time of day, feeding, cleaning, and harvesting. Clark et al. (1985) and Boardman et al. (1998) reported increases in nutrients and solids throughout the day and concentration peaks during raceway cleaning and harvesting. The data from this study were derived by random grab sampling and may not include pollutant spikes. However, pollutant spikes cannot be overlooked when addressing the quality of water discharged from a facility and should be further investigated to determine the magnitude and occurrences of such events.

\section{$5.4 \mathrm{BOD}_{5}$ vs. Turbidity}

In an effort to provide a real-time monitor of pollutant concentration, the relationship between turbidity and $\mathrm{BOD}_{5}$ was examined. The potential exists for operators with an inexpensive turbidity meter to estimate $\mathrm{BOD}_{5}$ concentration. To determine the existence of a correlation, turbidity measurements were considered the independent and $\mathrm{BOD}_{5}$ concentrations the dependent variables. The results were plotted for each individual site due to variability in raw water quality. Facilities $\mathrm{A}$ and $\mathrm{E}$ were the only two facilities that had consistent $\mathrm{BOD}_{5}$ measurements greater than the MDL $(2.86 \mathrm{mg} / \mathrm{L})$. Field measurements and sampling during 
times of high $\mathrm{BOD}_{5}$ discharge would give additional data and improve the results of this investigation.

Presented in Figure 5.4.1 is the turbidity vs. $\mathrm{BOD}_{5}$ plot for facility $\mathrm{A} . \mathrm{A} \mathrm{R}^{2}$ value of 0.7101 was calculated, however a majority of the measurements were taken at low turbidity and $\mathrm{BOD}_{5}$ concentrations.

Facility A

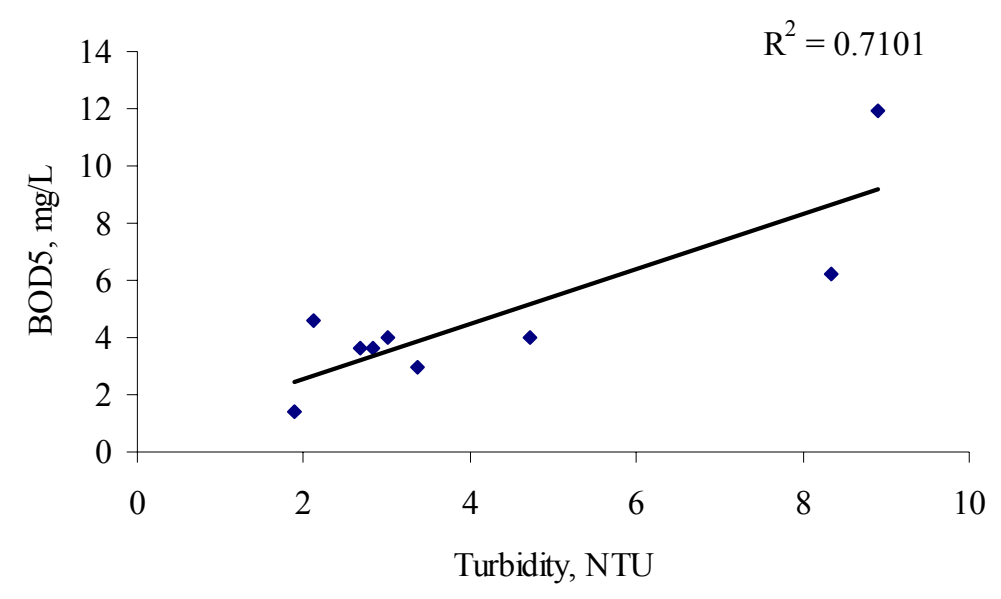

Figure 5.4.1. Turbidity vs. BOD 5 for Facility A.

Presented in Figure 5.4.2 is the turbidity vs. $\mathrm{BOD}_{5}$ plot for facility E. A $\mathrm{R}^{2}$ value of 0.0002 was calculated for this facility, but the low value was attributed to low turbidity and $\mathrm{BOD}_{5}$ measurements.

Facility E, Outlet

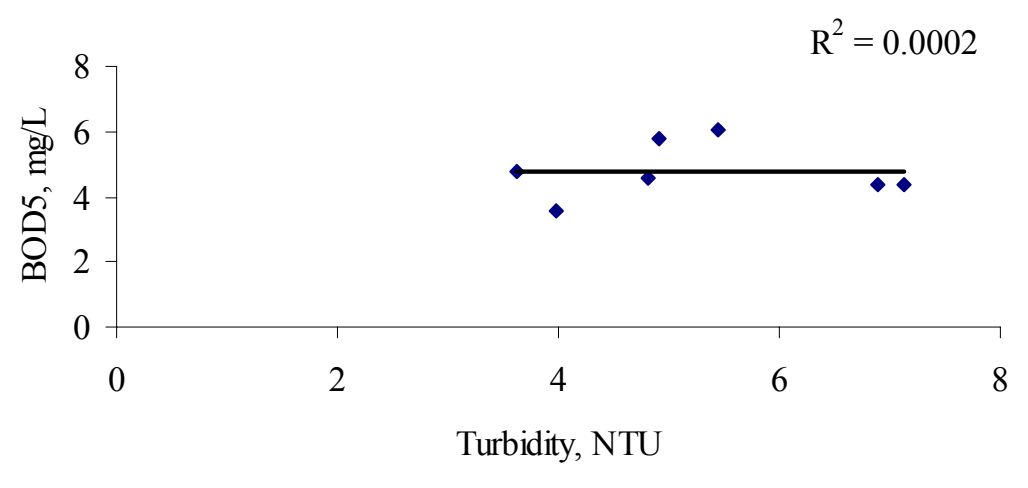

Figure 5.4.2. Turbidity vs. $\mathrm{BOD}_{5}$ for Facility $\mathrm{E}$. 
Presented in Figure 5.4.3 is a plot of turbidity and $\mathrm{BOD}_{5}$ for both facilities A and E. A R ${ }^{2}$ value of 0.5345 was calculated; however the low result was attributed to low measurements for both variables.

Facility A and E

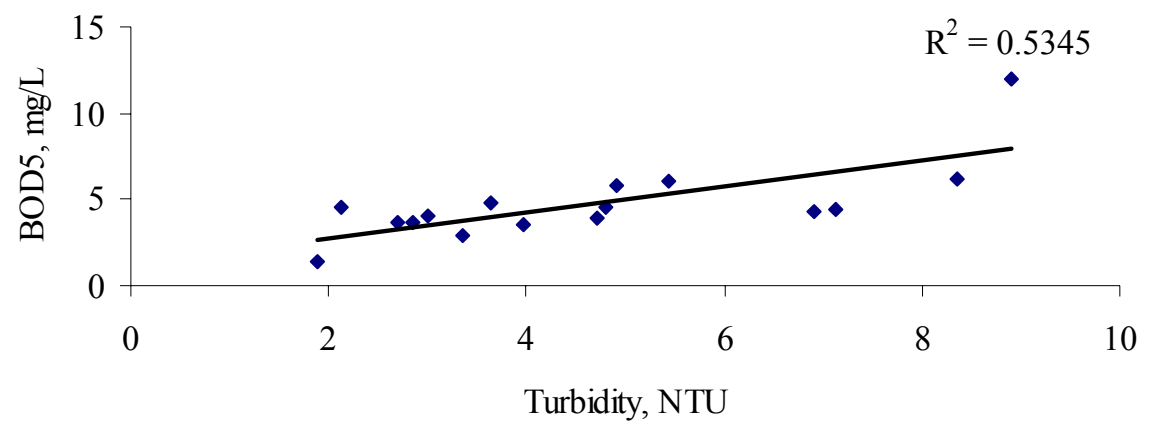

\section{Figure 5.4.3. Turbidity vs. $\mathrm{BOD}_{5}$ for Facilities $\mathrm{A}$ and $\mathrm{E}$.}

Although low $\mathrm{R}^{2}$ values were calculated for the respective facilities, a relationship existed between turbidity and $\mathrm{BOD}_{5}$. Sampling and analysis of facilities with higher fish densities or during production operations such as cleaning and harvesting may have resulted in higher turbidity and $\mathrm{BOD}_{5}$ measurements and thus a higher $\mathrm{R}^{2}$ values.

\subsection{Increased Production Potential}

The presented production numbers are based strictly on effluent pollutant load and discharge limitations and do not address the metabolic requirements of fish nor the capacity of the existing operations. Average discharge concentrations of regulated parameters (TSS, TAN, and $\mathrm{BOD}_{5}$ ) for each facility were compared to existing West Virginia discharge limitations. There exist the potential for increased production at each facility based on current permit limitations. Additionally, average discharge concentrations of TP for each facility were compared to discharge limitations in other States reported by Wedemeyer (2001). The difference between the pollutant limitation and discharge concentration represent a "freeboard" of potential 
increase in fish production. Using the calculated freeboard for each pollutant and the average discharge for each facility, the mass load freeboard was then calculated. The mass load of each pollutant was used to calculate an equivalent amount of feed and extrapolated to the fish production value of the feed (IDEQ, 1998). The species dependent calculating factors were based on a dry feed with $10 \%$ moisture, digestibility of $80 \%$ and a feed conversion of 1.2 .

Presented in Table 5.5.1 are the production impacts of effluent TSS limitation of 30, 20, 10, and $5 \mathrm{mg} / \mathrm{L}$. The current West Virginia NPDES limitation for average TSS concentration is $30 \mathrm{mg} / \mathrm{L}$. However, Wedemeyer (2001) reported average TSS limitations at Idaho, Washington, and Michigan facilities as 5, 5, and $4 \mathrm{mg} / \mathrm{L}$, respectively.

Table 5.5.1 Production impacts of various TSS effluent limitations.

\begin{tabular}{|c|c|c|c|c|c|c|c|c|}
\hline \multicolumn{3}{|c|}{$30 \mathrm{mg} / \mathrm{L}$ Limitation } & \multicolumn{2}{|c|}{$20 \mathrm{mg} / \mathrm{L}$ Limitation } & \multicolumn{2}{|c|}{$10 \mathrm{mg} / \mathrm{L}$ Limitation } & \multicolumn{2}{|c|}{$5 \mathrm{mg} / \mathrm{L}$ Limitation } \\
\hline Facility & $\begin{array}{l}\text { Change in } \\
\text { Production, } \\
\text { kg/year }\end{array}$ & $\begin{array}{l}\text { Percent } \\
\text { Change }\end{array}$ & $\begin{array}{l}\text { Change in } \\
\text { Production, } \\
\text { kg/year }\end{array}$ & $\begin{array}{l}\text { Percent } \\
\text { Change }\end{array}$ & $\begin{array}{l}\text { Change in } \\
\text { Production, } \\
\text { kg/year }\end{array}$ & $\begin{array}{l}\text { Percent } \\
\text { Change }\end{array}$ & $\begin{array}{l}\text { Change in } \\
\text { Production, } \\
\text { kg/year }\end{array}$ & $\begin{array}{l}\text { Percent } \\
\text { Change }\end{array}$ \\
\hline A & 133,555 & 147 & 61,285 & 68 & $-10,985$ & -12 & $-47,120$ & -52 \\
\hline B & 111,510 & 819 & 69,271 & 509 & 27,033 & 199 & 5,913 & 43 \\
\hline $\mathrm{C}$ & 40,922 & 301 & 23,230 & 171 & 5,538 & 41 & $-3,308$ & -24 \\
\hline $\mathrm{D}$ & 53,136 & 390 & 25,345 & 186 & $-2,446$ & -18 & $-16,341$ & -120 \\
\hline $\mathrm{E}$ & 225,593 & 392 & 123,515 & 215 & 21,436 & 37 & $-29,603$ & -51 \\
\hline $\mathrm{F}$ & 152,632 & 421 & 87,875 & 242 & 23,118 & 64 & $-9,260$ & -26 \\
\hline
\end{tabular}

As seen in Table 5.5.1, current West Virginia limitations would enable all facilities to increase production from 147 to $819 \%$, while a $5 \mathrm{mg} / \mathrm{L}$ limitation would result in reduced production at five facilities from 24 to $120 \%$ and an increase at one facility of $43 \%$.

Presented in Table 5.5.2 are the production impacts by an effluent TAN limitation of 10.44 and $5 \mathrm{mg} / \mathrm{L}$. The current West Virginia average discharge limitation for TAN is 10.44 $\mathrm{mg} / \mathrm{L}$. 
Table 5.5.2 Production impacts of two TAN effluent limitations.

\begin{tabular}{l|ll|ll}
\hline & $10.44 \mathrm{mg} / \mathrm{L}$ & & $5 \mathrm{mg} / \mathrm{L}$ & \\
\hline Facility & $\begin{array}{l}\text { Additional } \\
\text { Production, kg/year }\end{array}$ & Percent Change & $\begin{array}{l}\text { Additional } \\
\text { Production, kg/year }\end{array}$ & Percent Change \\
\hline A & 573,443 & 632 & 265,493 & 293 \\
B & 342,100 & 2,514 & 162,117 & 1,191 \\
C & 141,770 & 1,042 & 66,381 & 488 \\
D & 222,253 & 1,633 & 103,834 & 763 \\
E & 809,964 & 1,407 & 374,998 & 651 \\
F & 511,294 & 1,410 & 235,357 & 649 \\
\hline
\end{tabular}

As seen in Table 5.5.2, the current West Virginia limitation for TAN would enable all facilities to increase production from 632 to 2,514\%, while a $5 \mathrm{mg} / \mathrm{L}$ limitation would allow 293 to $1,191 \%$ increase in production

Presented in Table 5.5.3 are the production impacts of an effluent $\mathrm{BOD}_{5}$ limitation of 30 $\mathrm{mg} / \mathrm{L}$, the current West Virginia discharge limit.

Table 5.5.3 Production impacts of $\mathrm{BOD}_{5}$ effluent limitation.

\begin{tabular}{lll}
\hline & $30 \mathrm{mg} / \mathrm{L}$ & \\
\hline Facility & $\begin{array}{l}\text { Additional } \\
\text { Production, kg/year }\end{array}$ & Percent Change \\
\hline A & 182,843 & 202 \\
B & 120,676 & 887 \\
C & 50,052 & 368 \\
D & 76,647 & 563 \\
E & 261,729 & 455 \\
F & 176,463 & 487 \\
\hline
\end{tabular}

As seen in Table 5.5.3, the current West Virginia limitation for $\mathrm{BOD}_{5}$ would allow all facilities to increase production from 202 to $887 \%$. 
Presented in Table 5.5.4 are the production impacts of an effluent TP limitation of 0.1 and $1.0 \mathrm{mg} / \mathrm{L}$. Wedemeyer (2001) reported NPDES average effluent limits for TP as $0.1 \mathrm{mg} / \mathrm{L}$ at an Idaho hatchery. There is currently no effluent discharge limitation for TP at permitted West Virginia facilities.

Table 5.5.4 Production impacts at two TP effluent limitations.

\begin{tabular}{lllll}
\hline & $0.1 \mathrm{mg} / \mathrm{L}$ & & $1.0 \mathrm{mg} / \mathrm{L}$ & \\
\hline Facility & $\begin{array}{l}\text { Additional } \\
\text { Production, kg/year }\end{array}$ & Percent Change & $\begin{array}{l}\text { Additional } \\
\text { Production, kg/year }\end{array}$ & Percent Change \\
\hline A & $-22,643$ & -25 & 28,304 & 31 \\
B & 2,647 & 19 & 32,423 & 238 \\
C & 139 & 1 & 12,611 & 93 \\
D & $-1,959$ & -14 & 17,632 & 130 \\
E & $-3,998$ & -7 & 67,963 & 118 \\
F & 0 & 0 & 45,651 & 126 \\
\hline
\end{tabular}

As seen in Table 5.5.4, if a TP limitation of $0.1 \mathrm{mg} / \mathrm{L}$ was instituted at each facility, production would have to decrease from 7 to $25 \%$ for three facilities, could increase 1 and $19 \%$ at two facilities, while no change in production would be possible at the final site.

Based on the minimum amount of freeboard, the limiting factor for increased production at each facility was TSS, with increases ranging from 147 to 819 percent. 


\section{CHAPTER 6. SUMMARY AND CONCLUSIONS}

\subsection{Summary}

Close proximity to eastern markets and an abundance of water resources gives the aquaculture industry in West Virginia tremendous potential for growth. However, existing facilities must maximize their production to meet market demands, compete with new operations, and continue to meet effluent pollutant limitations. The purpose of this study was to provide industry, State, and Federal stakeholders with baseline water quality data specific to West Virginia facilities, in an effort to help concerned parties make informed decisions regarding impending regulations. Another objective of this research was to examine the potential for increases in production at each facility, based on effluent pollutant discharge requirements.

\subsubsection{Site Visits}

Each facility was visited and engineering process assessments were conducted through interviews and observations to establish PFDs, production techniques, and management practices. Influent and effluent field measurements of flowrate, $\mathrm{pH}$, temperature, $\mathrm{DO}$, turbidity, and specific conductance were taken at each facility to establish baseline conditions and for comparison with water quality criteria for trout production and effluent regulatory limits. Similarly, grab samples of influent and effluent at each facility were taken and measured for TSS, $\mathrm{BOD}_{5}$, TAN, $\mathrm{NO}_{2}{ }^{-}, \mathrm{NO}_{3}{ }^{-}$, and $\mathrm{TP}$ concentrations to establish baseline conditions and for comparison with water quality criteria for trout production and effluent regulatory limits.

\subsubsection{Data Analysis}

Flowrate and effluent pollutant concentrations were used to calculate mass loadings for comparison with current and anticipated regulatory limits. Water temperature, $\mathrm{pH}$, and TAN concentrations were used to calculate un-ionized ammonia concentrations for comparison with 
the known concentration toxic to trout. In order to provide operators with an inexpensive realtime indicator of pollutant discharge, turbidity and $\mathrm{BOD}_{5}$ measurements were examined to determine if a predictable relationship could be established. Additionally, average effluent pollutant concentration at each facility was used to calculate the potential to increase productivity, based on effluent regulatory limits.

\subsection{Conclusions}

\subsubsection{Effluent Characteristics}

Field measurements of influent and effluent at each facility were within acceptable ranges for trout production. Average effluent values of regulated field measurements of $\mathrm{pH}$ and $\mathrm{DO}$ were within current limitations. However, facilities A, D, and E each had one occurrence of DO concentration less than the regulatory limit of $6 \mathrm{mg} / \mathrm{L}$. The low DO measurements were attributed to the biological decomposition of organic matter, poor reaeration efficiency, and high fish density prior to discharge. Low DO occurrences could be corrected by the implementation of various reaeration techniques such as diffusion, mechanical aeration, and pure oxygen addition. Additionally, better management of fish biosolids (quick and permanent removal) to prevent over-accumulation would reduce DO depletion as organic matter decomposes.

Regulated parameters (TSS, $\mathrm{BOD}_{5}$, and TAN) were below current limitations in terms of concentration and mass load for all facilities. Concentration of grab sample pollutants (e.g., TSS, $\mathrm{BOD}_{5}, \mathrm{TAN}, \mathrm{NO}_{2}^{-}, \mathrm{NO}_{3}^{-}$, and TP), in general, had small increases from influent to effluent for all facilities, as a result of fish production. Generally, effluent pollutant concentrations were proportional to fish production, higher production equated higher pollutant concentration. However, facility $\mathrm{D}$ had low production numbers and relatively high pollutant concentration increases, which were attributed to the lack of effluent treatment. 


\subsubsection{Production Potential}

All participating facilities had the potential to increase production based on effluent pollutant concentration, mass load, and current effluent regulatory limits. Based on current limitations, the limiting factor for increased production at all facilities was TSS, though a minimum increase in production potential of $147 \%$ was attainable.

\subsubsection{Further Research}

Further study is warranted to examine effluent pollutant spikes during various hours of the day and during different management practices (e.g., feeding, harvesting, and raceway cleaning), to determine more accurately the extent that existing water resources at each facility can be utilized to increase production, reaeration efficiencies of each facility, and the effectiveness of various treatment methods to enable further productivity while maintaining regulatory compliance. 


\section{CHAPTER 7. REFERENCES}

APHA (American Public Health Association). 1985. Standard Methods for the Examination of Water and Wastewater, $16^{\text {th }}$ Edition. Washington, D.C.

Axler, R.P., Tikkanen, C., Henneck J., Schuldt, J., and McDonald, M.E. 1997. "Characteristics of Effluent and Sludge from Two Commercial Rainbow Trout Farms in Minnesota." The Progressive Fish-Culturist 59: 161-172.

Boaventura, R., Pedro, A.M., Coimbra, J., and Lencastre, E. 1997. "Trout Farm Effluents: Characterization and Impacts on the Receiving Streams." Environmental Pollution 95: 379-387.

Boardman, G.D., Maillard, V., Nyland, J., Flick, G.J., and Libey, G.S. 1998. The Characterization, Treatment and Improvement of Aquaculture Effluents. Virginia Polytechnical Institute, Blacksburg, Virginia.

Buttner, J.K., Soderberg, R.W., and Terlizzi, D.E. 1993. "An Introduction to Water Chemistry in Freshwater Aquaculture." Northeastern Regional Aquaculture Center Factsheet 170.

Cho, C.Y. 1997. "Reduction of Waste Output from Salmonid Aquaculture through Feeds and Feeding." The Progressive Fish-Culturist 59: 155-160.

Colt, J.E. and Tomasso, J.R. 2001. "Hatchery Water Supply and Treatment." Wedemeyer, G. (Ed.), Fish Hatchery Management, $2^{\text {nd }}$ Edition (pp 91-186). American Fisheries Society, Bethesda, Maryland.

Davis, J.T. 1993. "Survey of Aquaculture Effluent Permitting and 1993 Standards in the South." Southern Regional Aquaculture Center Publication No. 465.

Enell, M. 1995. "Environmental Impact of Nutrients from Nordic Fish Farming." Water Science and Technology 31: 61-71.

Eqart, J.W., Hankins, J., and Bullock, D. 1995. "State Policies for Aquaculture Effluents and Solid Wastes in the Northeast Region." Northeastern Regional Aquaculture Center Bulletin No. 300 .

Gatlin, D.M., III, and Hardy, R.W. 2002. "Manipulations of Diets and Feeding to Reduce Losses of Nutrients in Intensive Aquaculture." Aquaculture and the Environment in the United States, U.S. Aquaculture Society, Baton Rouge, Louisiana.

Hargreaves and Brunson. 1996. "Carbon Dioxide in Fish Ponds." Southern Regional Aquaculture Center. Publication No. 468.

Heinen, J.M. 1996. "Water Quality Criteria, Uptake, Bioaccumulation, and Public Health Considerations for Chemicals of Possible Concern in West Virginia Mine Waters Used for 
Culture of Rainbow Trout." The Conservation Fund's Freshwater Institute, Shepherdstown, West Virginia.

Hinshaw, J. 2000. "Trout Farming: Carrying Capacity and Inventory Management." Southern Regional Aquaculture Center Publication No. 222.

Hinshaw, J.M., and Fornshell, G. 2002. "Effluents from Raceways." Aquaculture and the Environment in the United States, U.S. Aquaculture Society, Baton Rouge, Louisiana.

IDEQ (Idaho Division of Environmental Quality). 1998. Idaho Waste Management Guidelines for Aquaculture Operations. Idaho Department of Health and Welfare, Division of Environmental Quality, Twin Falls, Idaho.

Isco, Inc. 1988. Open Channel Flow Measurement Handbook. $2^{\text {nd }}$ Edition. Lincoln, Nebraska.

Klontz, G.W. 1995. Quantitative Methods for Intensive Aquaculture. University of Idaho, Moscow, Idaho.

Kolsäter, L. 1995. "Feed Management and Reduction of Aquaculture Wastes." Water Science and Technology 31: 213-218.

Lanari, D, D'Agaro, E., and Ballestrazzi, R. 1995. "Dietary N and P Levels, Effluent Water Characteristics and Performance in Rainbow Trout." Water Science and Technology 31:157165.

Lin, S.D. 2001. Water and Wastewater Calculations Manual. McGraw-Hill, New York, New York.

Mayer, I., and McLean, E. 1995. "Bioengineering and Biotechnological Strategies for Reduced Waste Aquaculture.” Water Science and Technology 31: 85-102.

Mazik, P.M. and Parker, N.C. 2001. "Semicontrolled Systems." Wedemeyer, G. (Ed.), Fish Hatchery Management, $2^{\text {nd }}$ Edition (pp 241-284). American Fisheries Society, Bethesda, Maryland.

Meade, J.W. 1989. Aquaculture Management. Van Nostrand Reinhold, New York.

Médale, F., Brauge, C., Vallée, F., and Kaushik, S.J. 1995. "Effects of Dietary Protein/Energy Ratio, Ration Size, Dietary Energy Source and Water Temperature on Nitrogen Excretion in Rainbow Trout." Water Science and Technology 31: 185-194.

Metcalf \& Eddy, Inc. 2003. Wastewater Engineering: Treatment and Reuse. McGraw-Hill, New York, New York. 
Mugg, J., Serrano, A., Liberti, A, and Rice, M.A. "Aquaculture Effluents: A Guide for Water Quality Regulators and Aquaculturist" Northeastern Regional Aquaculture Center Bulletin No. 00-003.

Naylor, S.J., Moccia, R.D., and Durant, G.M. 1999. "The Chemical Composition of Settleable Solid Fish Waste (Manure) from Commercial Rainbow Trout Farms in Ontario, Canada." North American Journal of Aquaculture 61:21-26.

Piper, R.G., McElwain, I.B., Orme, L.E., McCraren, J.P., Fowler, L.G., and Leonard, J.R. 1982. "Fish Hatchery Management." U.S. Fish and Wildlife Service, Washington, D.C.

Ramseyer, L.J. and Garling, D.L. 1997. "Fish Nutrition and Aquaculture Waste Management." Proceedings of the 1997 North Central Aquaculture Conference, Indianpolis, IN. Illinios-Indiana Sea Grant Program, Publication CES-305 57-62.

Redding, T., Todd, S., and Midlen, A. 1997. "The Treatment of Aquaculture Wastewaters - A Botanical Approach." Journal of Environmental Management 50: 283-299.

Rodriques, A.M.P. 1995. "Biological and Nutritional Approach to the Environmental Impact of Trout Culture in Portugal." Water Science and Technology 31: 239-248.

Sawyer, C.N., McCarty, P.L., and Parkin, G.F. 1994. Chemistry for Environmental Engineering, $4^{\text {th }}$ Edition, McGraw-Hill, Inc., New York, New York.

Selong, J.H., and Helfrich, L.A. 1998. "Impacts of Trout Culture Effluent of Water Quality and Biotic Communities in Virginia Headwater Streams." The Progressive Fish-Culturist 60:247262.

Smearman, S.C., D’Souza, G.E., and Norton, V.J. 1997. “External Costs of Aquaculture Production in West Virginia." Environmental and Resource Economics 10: 167-175.

Snoeyink, V.L. and Jenkins, D. 1980. Water Chemistry. John Wiley \& Sons, Inc., New York, New York.

Soderberg, R.W. 1995. Flowing Water Fish Culture. Lewis Publishers, Boca Raton, Florida. Summerfelt, S., Bebak-Williams, J., and Tsukuda, S. 2001. "Controlled Systems: Water Reuse and Recirculation." Wedemeyer, G. (Ed.), Fish Hatchery Management, $2^{\text {nd }}$ Edition (pp 285395). American Fisheries Society, Bethesda, Maryland.

Stumm, W. and Morgan, J.J. 1996. Aquatic Chemistry. John Wiley \& Sons, Inc., New York, New York.

United States Department of Agriculture. Electronic Outlook Report from the Economic Research Service. National Agriculture Statistics Service, LDP=AQS-15. 2002. 
USEPA, 1998. "Guidance for Data Quality Assessment, Practical Methods for Data Analysis." EPA 600-R-96-084, Office of Research and Development, U.S. Environmental Protection Agency, Washington, D.C.

USEPA. 1982. "Handbook for Sampling and Sample Preservation of Water and Wastewater." EPA 600/4-82-029, U.S. Environmental Protection Agency, Washington, D.C.

USEPA. 1997. "Volunteer Stream Monitoring: A Methods Manual.” EPA 841-B-97-003, U.S. Environmental Protection Agency, Washington, D.C.

USEPA. 1999. "Methods and Guidance for Analysis of Water." EPA 821-C-99-001, U.S. Environmental Protection Agency, Washington, D.C.

Westers, H. 1984. Principles of Intensive Fish Culture. Michigan Department of Natural Resources, Lansing, Michigan.

West Virginia Department of Environmental Protection. National Pollutant Discharge Elimination System. Permit No. WV0111821. Charleston, West Virginia, 1993.

Westers, H. 2001. "Production.” Wedemeyer, G. (Ed.), Fish Hatchery Management, $2^{\text {nd }}$ Edition (pp 31-89). American Fisheries Society, Bethesda, Maryland.

Wurts, W.A. and Durborow, R.M. 1992. "Interactions of pH, Carbon Dioxide, Alkalinity and Hardness in Fish Ponds." Southern Regional Aquaculture Center Publication No. 464. 


\section{APPENDIX A}

Table A.1. Facility A Flow, pH, and Temperature.

\begin{tabular}{lcccccc}
\multicolumn{1}{c}{ Date } & $\begin{array}{c}\text { Flow, } \\
\text { gal./min. }\end{array}$ & $\begin{array}{c}\text { Flow, } \\
\text { m3/day }\end{array}$ & $\begin{array}{c}\text { Influent } \\
\mathrm{pH}\end{array}$ & $\mathrm{pH}$ & $\begin{array}{c}\text { Influent } \\
\text { Temperature, } \\
{ }^{\circ} \mathrm{C}\end{array}$ & $\begin{array}{c}\text { Temperature, } \\
{ }^{\circ} \mathrm{C}\end{array}$ \\
\hline $1 / 4 / 01$ & 1344 & 7325.34 & 7.46 & 7.03 & 7.3 & 5.8 \\
$3 / 26 / 01$ & 1056 & 5755.62 & 7.08 & 7.19 & 7.3 & 7 \\
$5 / 16 / 01$ & 1508 & 8219.20 & 7.11 & 6.82 & 10.4 & 10.9 \\
$7 / 5 / 01$ & 1556 & 8480.82 & 6.57 & 6.71 & 12.2 & 14.1 \\
$8 / 8 / 01$ & 1850 & 10083.24 & 7.57 & 7.31 & 12.8 & 16.3 \\
$9 / 25 / 01$ & 1276 & 6954.71 & 7.37 & 7.2 & 11.7 & 13.2 \\
$11 / 19 / 01$ & 754 & 4109.60 & 7.50 & 7.49 & 11.4 & 10.5 \\
$6 / 6 / 02$ & 1409 & 7679.61 & 6.92 & 6.89 & 11.6 & 13.2 \\
$10 / 13 / 02$ & 1017 & 5543.06 & 6.91 & 7.08 & 12.1 & 13.6 \\
\hline Min. & 754.00 & 4109.60 & 6.57 & 6.71 & 7.30 & 5.80 \\
Max. & 1850.00 & 10083.24 & 7.57 & 7.49 & 12.80 & 16.30 \\
Avg. & 1307.78 & 7127.91 & 7.17 & 7.08 & 10.76 & 11.62
\end{tabular}

Table A.2. Facility A DO, Turbidity, and Specific Conductance.

\begin{tabular}{lcccccc}
\multicolumn{1}{c}{ Date } & $\begin{array}{c}\text { Influent } \\
\text { Dissolved } \\
\text { Oxygen, } \\
\text { mg/L }\end{array}$ & $\begin{array}{c}\text { Dissolved } \\
\text { Oxygen, } \\
\text { mg/L }\end{array}$ & $\begin{array}{c}\text { Influent } \\
\text { Turbidity, } \\
\text { NTU }\end{array}$ & $\begin{array}{c}\text { Influent } \\
\text { Turbidity, } \\
\text { NTU }\end{array}$ & $\begin{array}{c}\text { Specific } \\
\text { Conductance, } \\
\mu \text { S/cm }\end{array}$ & $\begin{array}{c}\text { Specific } \\
\text { Conductance, } \\
\mu \text { S/cm }\end{array}$ \\
\hline $1 / 4 / 01$ & 8.53 & 8.52 & 1.08 & 1.88 & 157.4 & 156.9 \\
$3 / 26 / 01$ & 9.25 & 9.55 & 4.81 & 8.35 & 150.6 & 144.1 \\
$5 / 16 / 01$ & 8.44 & 7.82 & 0.69 & 3.01 & 161.8 & 170.4 \\
$7 / 5 / 01$ & 9.25 & 6.33 & 1.31 & 8.91 & 185.3 & 198.3 \\
$8 / 8 / 01$ & 9.27 & 5.94 & 1.73 & 2.84 & 174.6 & 192.2 \\
$9 / 25 / 01$ & 11.06 & 7.16 & 0.54 & 4.71 & 229.5 & 245.4 \\
$11 / 19 / 01$ & 8.86 & 7.16 & 0.57 & 2.69 & 233.6 & 245.3 \\
$6 / 6 / 02$ & 9.48 & 6.84 & 1.84 & 2.13 & 148.7 & 160.5 \\
$10 / 13 / 02$ & 8.27 & 5.92 & 1.95 & 3.36 & 230.5 & 242.5 \\
\hline Min. & 8.27 & 5.92 & 0.54 & 1.88 & 148.70 & 144.10 \\
Max. & 11.06 & 9.55 & 4.81 & 8.91 & 233.60 & 245.40 \\
Avg. & 9.16 & 7.25 & 1.61 & 4.21 & 185.78 & 195.07
\end{tabular}


Table A.3. Facility A TSS and TAN.

\begin{tabular}{|c|c|c|c|c|c|c|}
\hline Date & $\begin{array}{c}\text { Influent } \\
\text { Total } \\
\text { Suspended } \\
\text { Solids } \\
\text { (TSS), } \\
\text { mg/L }\end{array}$ & $\begin{array}{c}\text { Influent } \\
\text { Total } \\
\text { Suspended } \\
\text { Solids } \\
\text { (TSS), } \\
\text { kg/day }\end{array}$ & $\begin{array}{c}\text { Total } \\
\text { Suspended } \\
\text { Solids } \\
\text { (TSS), } \\
\text { mg/L }\end{array}$ & $\begin{array}{c}\text { Total } \\
\text { Suspended } \\
\text { Solids } \\
\text { (TSS), } \\
\text { kg/day }\end{array}$ & $\begin{array}{c}\text { Influent } \\
\text { Ammonia } \\
\text { Nitrogen } \\
\text { (TAN), } \\
\text { mg/L }\end{array}$ & $\begin{array}{c}\text { Influent } \\
\text { Ammonia } \\
\text { Nitrogen } \\
\text { (TAN), } \\
\text { kg/day }\end{array}$ \\
\hline $1 / 4 / 01$ & $32 *$ & & 14 & 102.55 & 0.153 & 1.121 \\
\hline $3 / 26 / 01$ & 2 & 11.51 & 14 & 80.58 & 0.01 & 0.058 \\
\hline $5 / 16 / 01$ & 1 & 8.22 & 15 & 123.29 & 0.04 & 0.329 \\
\hline $7 / 5 / 01$ & 2.5 & 21.20 & 17.5 & 148.41 & 0.125 & 1.060 \\
\hline $8 / 8 / 01$ & 2 & 20.17 & 10 & 100.83 & 0.010 & 0.101 \\
\hline $9 / 25 / 01$ & 4 & 27.82 & 8.7 & 60.51 & 0.005 & 0.035 \\
\hline $11 / 19 / 01$ & 3 & 12.33 & 4.5 & 18.49 & 0.03 & 0.107 \\
\hline $6 / 6 / 02$ & 2.5 & 19.20 & 11 & 84.48 & 0.08 & 0.614 \\
\hline $10 / 13 / 02$ & 3 & 16.63 & 9 & 49.89 & 0.14 & 0.776 \\
\hline Min. & 1.00 & 8.22 & 4.50 & 18.49 & 0.01 & 0.03 \\
\hline Max. & 4.00 & 27.82 & 17.50 & 148.41 & 0.15 & 1.12 \\
\hline Avg. & 2.50 & 17.13 & 11.52 & 85.45 & 0.07 & 0.47 \\
\hline
\end{tabular}

Table A.4. Facility $\mathrm{A} \mathrm{NH}_{3}$, TAN, and $\mathrm{NO}_{3}$.

\begin{tabular}{|c|c|c|c|c|c|c|c|}
\hline Date & $\begin{array}{c}\text { Influent } \\
\text { Unionized } \\
\text { Ammonia } \\
\text { Nitrogen } \\
\left(\mathrm{NH}_{3}\right), \\
\mathrm{mg} / \mathrm{L} \\
\end{array}$ & $\begin{array}{c}\text { Ammonia } \\
\text { Nitrogen } \\
\text { (TAN), } \\
\text { mg/L } \\
\end{array}$ & $\begin{array}{c}\text { Ammonia } \\
\text { Nitrogen } \\
\text { (TAN), } \\
\text { Kg/day } \\
\end{array}$ & $\begin{array}{c}\text { Unionized } \\
\text { Ammonia } \\
\text { Nitrogen } \\
\left(\mathrm{NH}_{3}\right), \\
\mathrm{mg} / \mathrm{L} \\
\end{array}$ & $\begin{array}{c}\text { Influent } \\
\text { Nitrate } \\
\text { Nitrogen } \\
\left(\mathrm{NO}_{3}\right) \text {, } \\
\mathrm{mg} / \mathrm{L} \\
\end{array}$ & $\begin{array}{c}\text { Influent } \\
\text { Nitrate } \\
\text { Nitrogen } \\
\left(\mathrm{NO}_{3}\right) \text {, } \\
\mathrm{kg} / \text { day } \\
\end{array}$ & $\begin{array}{c}\text { Nitrate } \\
\text { Nitrogen } \\
\left(\mathrm{NO}_{3}\right), \\
\mathrm{mg} / \mathrm{L} \\
\end{array}$ \\
\hline $1 / 4 / 01$ & 0.00066 & 0.4 & 2.93 & 0.00057 & 0.514 & 3.765 & 1.507 \\
\hline $3 / 26 / 01$ & 0.00002 & 0.357 & 2.05 & 0.00081 & 0.893 & 5.140 & 1.63 \\
\hline $5 / 16 / 01$ & 0.00010 & 0.212 & 1.74 & 0.00028 & 0.542 & 4.455 & 1.09 \\
\hline $7 / 5 / 01$ & 0.00010 & 0.459 & 3.89 & 0.00060 & 0.613 & 5.199 & 0.954 \\
\hline $8 / 8 / 01$ & 0.00008 & 0.53 & 5.34 & 0.00324 & 1.530 & 15.427 & 0.901 \\
\hline $9 / 25 / 01$ & 0.00002 & 0.15 & 1.04 & 0.00056 & 0.7139 & 4.965 & 0.937 \\
\hline $11 / 19 / 01$ & 0.00017 & 0.14 & 0.58 & 0.00083 & 0.5397 & 2.218 & 1.75 \\
\hline $6 / 6 / 02$ & 0.00014 & 0.25 & 1.92 & 0.00046 & 0.4600 & 3.533 & 0.85 \\
\hline $10 / 13 / 02$ & 0.00025 & 0.3 & 1.66 & 0.00088 & 1.0000 & 5.543 & 1.92 \\
\hline Min. & 0.00002 & 0.14 & 0.58 & 0.00028 & 0.46 & 2.22 & 0.85 \\
\hline Max. & 0.00066 & 0.53 & 5.34 & 0.00324 & 1.53 & 15.43 & 1.92 \\
\hline Avg. & 0.00017 & 0.31 & 2.35 & 0.00091 & 0.76 & 5.58 & 1.28 \\
\hline
\end{tabular}


Table A.5. Facility $\mathrm{A} \mathrm{NO}_{3}, \mathrm{NO}_{2}$, and TP.

\begin{tabular}{lcccccc} 
& $\begin{array}{c}\text { Nitrate } \\
\text { Nitrogen } \\
\left(\mathrm{NO}_{3}\right),\end{array}$ & $\begin{array}{c}\text { Influent } \\
\text { Nitrite } \\
\text { Nitrogen } \\
\left(\mathrm{NO}_{2}\right), \\
\mathrm{mg} / \mathrm{L} \text { day }\end{array}$ & $\begin{array}{c}\text { Nitrite } \\
\text { itrogen } \\
\left(\mathrm{NO}_{2}\right), \\
\mathrm{mg} / \mathrm{L}\end{array}$ & $\begin{array}{c}\text { Nitrite } \\
\text { Nitrogen } \\
\left(\mathrm{NO}_{2}\right), \\
\mathrm{Kg}_{\text {day }}\end{array}$ & $\begin{array}{c}\text { Influent } \\
\text { Total } \\
\text { Phosphorus } \\
(\mathrm{TP}), \mathrm{mg} / \mathrm{L}\end{array}$ & $\begin{array}{c}\text { Influent } \\
\text { Total } \\
\text { Phosphorus } \\
(\mathrm{TP}), \\
\mathrm{kg} / \mathrm{day}\end{array}$ \\
\hline $1 / 4 / 01$ & 11.04 & 0.01 & 0.01 & 0.07 & 0.0005 & 0.004 \\
$3 / 26 / 01$ & 9.38 & 0.01 & 0.023 & 0.13 & 0.0005 & 0.003 \\
$5 / 16 / 01$ & 8.96 & 0.01 & 0.01 & 0.08 & 0.0005 & 0.004 \\
$7 / 5 / 01$ & 8.09 & 0.01 & 0.01 & 0.08 & 0.0093 & 0.079 \\
$8 / 8 / 01$ & 9.08 & 0.01 & 0.01 & 0.10 & 0.0005 & 0.005 \\
$9 / 25 / 01$ & 6.52 & 0.01 & 0.01 & 0.07 & 0.0180 & 0.125 \\
$11 / 19 / 01$ & 7.19 & 0.01 & 0.024 & 0.10 & 0.03500 & 0.144 \\
$6 / 6 / 02$ & 6.53 & 0.01 & 0.01 & 0.08 & 0.018 & 0.138 \\
$10 / 13 / 02$ & 10.64 & 0.01 & 0.01 & 0.06 & 0.001 & 0.003 \\
\hline Min. & 6.52 & 0.01 & 0.01 & 0.06 & 0.0005 & 0.0028 \\
Max. & 11.04 & 0.01 & 0.02 & 0.13 & 0.0350 & 0.1438 \\
Avg. & 8.60 & 0.01 & 0.01 & 0.09 & 0.0092 & 0.0561
\end{tabular}

Table A.6. Facility A TP, and BOD .

\begin{tabular}{|c|c|c|c|c|c|c|}
\hline Date & $\begin{array}{c}\text { Total } \\
\text { Phosphorus } \\
\text { (TP), mg/L }\end{array}$ & $\begin{array}{c}\text { Total } \\
\text { Phosphorus } \\
\text { (TP), } \\
\text { Kg/day } \\
\end{array}$ & $\begin{array}{c}\text { Influent } \\
\text { Biochemical } \\
\text { Oxygen } \\
\text { Demand } \\
\left(\mathrm{BOD}_{5}\right), \\
\mathrm{mg} / \mathrm{L} \\
\end{array}$ & $\begin{array}{c}\text { Influent } \\
\text { Biochemical } \\
\text { Oxygen } \\
\text { Demand } \\
\left(\mathrm{BOD}_{5}\right) \\
\mathrm{mg} / \mathrm{L} \\
\end{array}$ & $\begin{array}{c}\text { Biochemical } \\
\text { Oxygen } \\
\text { Demand } \\
\left(\mathrm{BOD}_{5}\right), \\
\mathrm{mg} / \mathrm{L} \\
\end{array}$ & $\begin{array}{c}\text { Biochemical } \\
\text { Oxygen } \\
\text { Demand } \\
\left(\mathrm{BOD}_{5}\right), \\
\mathrm{Kg} / \text { day }\end{array}$ \\
\hline $1 / 4 / 01$ & 0.279 & 2.04 & 1.43 & 10.4752 & 1.43 & 10.48 \\
\hline $3 / 26 / 01$ & 0.413 & 2.38 & 1.43 & 8.23054 & 6.22 & 35.80 \\
\hline $5 / 16 / 01$ & 0.233 & 1.92 & 1.43 & 11.7535 & 3.98 & 32.71 \\
\hline $7 / 5 / 01$ & 1.24 & 10.52 & 1.43 & 12.1276 & 11.96 & 101.43 \\
\hline $8 / 8 / 01$ & 0.221 & 2.23 & 1.43 & 14.419 & 3.61 & 36.40 \\
\hline $9 / 25 / 01$ & 0.622 & 4.33 & 1.43 & 9.94524 & 3.97 & 27.61 \\
\hline $11 / 19 / 01$ & 0.292 & 1.20 & 1.43 & 5.87673 & 3.6 & 14.79 \\
\hline $6 / 6 / 02$ & 0.408 & 3.13 & 1.43 & 10.8 & 4.6 & 35.33 \\
\hline $10 / 13 / 02$ & 0.81 & 4.49 & 1.43 & 7.92657 & 2.95 & 16.35 \\
\hline Min. & 0.22 & 1.20 & 1.43 & 5.88 & 1.43 & 10.48 \\
\hline Max. & 1.24 & 10.52 & 1.43 & 14.42 & 11.96 & 101.43 \\
\hline Avg. & 0.50 & 3.58 & 1.43 & 10.19 & 4.70 & 34.54 \\
\hline
\end{tabular}




\section{APPENDIX B}

Table B.1. Facility B Flow, pH, and Temperature.

\begin{tabular}{ccccccc} 
Date & $\begin{array}{c}\text { Flow, } \\
\text { gal./min. }\end{array}$ & $\begin{array}{c}\text { Flow, } \\
\mathrm{m} 3 / \text { day }\end{array}$ & $\begin{array}{c}\text { Influent } \\
\mathrm{pH}\end{array}$ & $\mathrm{pH}$ & $\begin{array}{c}\text { Influent } \\
\text { Temperature, } \\
{ }^{\circ} \mathrm{C}\end{array}$ & $\begin{array}{c}\text { Temperature, } \\
{ }^{\circ} \mathrm{C}\end{array}$ \\
\hline $11 / 10 / 00$ & 209 & 1139.13 & 7.51 & 7.64 & 12.2 & 12 \\
$1 / 4 / 01$ & 634 & 3455.55 & 7.92 & 8.08 & 9.9 & 10.9 \\
$3 / 26 / 01$ & 896 & 4883.56 & 7.55 & 7.27 & 9.3 & 13.2 \\
$5 / 16 / 01$ & 1541 & 8399.07 & 6.88 & 7.35 & 11.2 & 12 \\
$7 / 5 / 01$ & 824 & 4491.13 & 7.22 & 7.04 & 12.3 & 11.4 \\
$8 / 8 / 01$ & 1347 & 7341.69 & 7.60 & 7.8 & 13.4 & 14.6 \\
$9 / 25 / 01$ & 822 & 4480.23 & 7.25 & 7.26 & 12.6 & 18.7 \\
$11 / 19 / 01$ & 480 & 2616.19 & 7.70 & 7.56 & 12.2 & 19.7 \\
$6 / 6 / 02$ & 332 & 1809.53 & 7.29 & 7.29 & 11.9 & 12.2 \\
$10 / 13 / 02$ & 558 & 3041.32 & 7.16 & 7.5 & 13.1 & 13.4 \\
\hline Min. & 209.00 & 1139.13 & 6.88 & 7.04 & 9.30 & 10.90 \\
Max. & 1541.00 & 8399.07 & 7.92 & 8.08 & 13.40 & 19.70 \\
Avg. & 764.30 & 4165.74 & 7.41 & 7.48 & 11.81 & 13.81
\end{tabular}

Table B.2. Facility B DO, Turbidity, and Specific Conductance.

\begin{tabular}{ccccccc} 
Influent & $\begin{array}{c}\text { Dissolved } \\
\text { Oxygen, } \\
\text { mg/L }\end{array}$ & $\begin{array}{c}\text { Dissolved } \\
\text { Oxygen, } \\
\text { mg/L }\end{array}$ & $\begin{array}{c}\text { Influent } \\
\text { Turbidity, } \\
\text { NTU }\end{array}$ & $\begin{array}{c}\text { Turbidity, } \\
\text { NTU }\end{array}$ & $\begin{array}{c}\text { Influent } \\
\text { Specific } \\
\text { Conductance, } \\
\mu \mathrm{S} / \mathrm{cm}\end{array}$ & $\begin{array}{c}\text { Specific } \\
\text { Conductance, } \\
\mu \mathrm{S} / \mathrm{cm}\end{array}$ \\
\hline $11 / 10 / 00$ & 8.88 & 7.8 & 1.17 & 1.22 & 343.8 & 347.6 \\
$1 / 4 / 01$ & 9.76 & 9.87 & 1.03 & 0.39 & 312.4 & 326.8 \\
$3 / 26 / 01$ & 9.86 & 12.15 & 5.92 & 6.14 & 270.4 & 232.6 \\
$5 / 16 / 01$ & 9.42 & 10.35 & 0.86 & 0.95 & 312.7 & 309.7 \\
$7 / 5 / 01$ & 9.85 & 12.13 & 1.29 & 1.23 & 320.6 & 320.3 \\
$8 / 8 / 01$ & 9.04 & 12.67 & 1.62 & 2.2 & 343.2 & 340.1 \\
$9 / 25 / 01$ & 10.06 & 10.36 & 1.27 & 1.28 & 333.6 & 336.2 \\
$11 / 19 / 01$ & 8.59 & 10.42 & 0.54 & 1.66 & 166.5 & 313.7 \\
$6 / 6 / 02$ & 9.53 & 8.42 & 1.26 & 1.66 & 312.7 & 313.8 \\
$10 / 13 / 02$ & 8.28 & 8.17 & 1.71 & 1.23 & 360 & 357.1 \\
\hline Min. & 8.28 & 7.80 & 0.54 & 0.39 & 166.50 & 232.60 \\
Max. & 10.06 & 12.67 & 5.92 & 6.14 & 360.00 & 357.10 \\
Avg. & 9.33 & 10.23 & 1.67 & 1.80 & 307.59 & 319.79
\end{tabular}


Table B.3. Facility B TSS and TAN.

\begin{tabular}{|c|c|c|c|c|c|c|}
\hline Date & $\begin{array}{c}\text { Influent } \\
\text { Total } \\
\text { Suspended } \\
\text { Solids } \\
\text { (TSS), } \\
\text { mg/L }\end{array}$ & $\begin{array}{c}\text { Influent } \\
\text { Total } \\
\text { Suspended } \\
\text { Solids } \\
\text { (TSS), } \\
\text { kg/day }\end{array}$ & $\begin{array}{c}\text { Total } \\
\text { Suspended } \\
\text { Solids } \\
\text { (TSS), } \\
\text { mg/L }\end{array}$ & $\begin{array}{c}\text { Total } \\
\text { Suspended } \\
\text { Solids } \\
\text { (TSS), } \\
\text { kg/day }\end{array}$ & $\begin{array}{c}\text { Influent } \\
\text { Ammonia } \\
\text { Nitrogen } \\
\text { (TAN), } \\
\text { mg/L }\end{array}$ & $\begin{array}{c}\text { Influent } \\
\text { Ammonia } \\
\text { Nitrogen } \\
\text { (TAN), } \\
\text { kg/day }\end{array}$ \\
\hline $11 / 10 / 00$ & 4 & 4.56 & 6 & 6.83 & 0.099 & 0.113 \\
\hline $1 / 4 / 01$ & 2.5 & 8.64 & 2.5 & 8.64 & 0.151 & 0.522 \\
\hline $3 / 26 / 01$ & 0.5 & 2.44 & 2 & 9.77 & 0.005 & 0.024 \\
\hline $5 / 16 / 01$ & 0.5 & 4.20 & 3 & 25.20 & 0.035 & 0.294 \\
\hline $7 / 5 / 01$ & 1 & 4.49 & 5 & 22.46 & 0.156 & 0.701 \\
\hline $8 / 8 / 01$ & 2 & 14.68 & 3 & 22.03 & 0.020 & 0.147 \\
\hline $9 / 25 / 01$ & 1 & 4.48 & 4.5 & 20.16 & 0.005 & 0.022 \\
\hline $11 / 19 / 01$ & 1 & 2.62 & 2 & 5.23 & 0.005 & 0.013 \\
\hline $6 / 6 / 02$ & 2 & 3.62 & 3 & 5.43 & 0.04 & 0.072 \\
\hline $10 / 13 / 02$ & 3 & 9.12 & 5 & 15.21 & 0.14 & 0.426 \\
\hline Min. & 0.50 & 2.44 & 2.00 & 5.23 & 0.01 & 0.01 \\
\hline Max. & 4.00 & 14.68 & 6.00 & 25.20 & 0.16 & 0.70 \\
\hline Avg. & 1.75 & 5.89 & 3.60 & 14.09 & 0.07 & 0.23 \\
\hline
\end{tabular}

Table B.4. Facility $\mathrm{B} \mathrm{NH}$, TAN, and $\mathrm{NO}_{3}$.

\begin{tabular}{|c|c|c|c|c|c|c|c|}
\hline Date & $\begin{array}{c}\text { Influent } \\
\text { Unionized } \\
\text { Ammonia } \\
\text { Nitrogen } \\
\left(\mathrm{NH}_{3}\right), \\
\mathrm{mg} / \mathrm{L} \\
\end{array}$ & $\begin{array}{c}\text { Ammonia } \\
\text { Nitrogen } \\
\text { (TAN), } \\
\text { mg/L }\end{array}$ & $\begin{array}{c}\text { Ammonia } \\
\text { Nitrogen } \\
\text { (TAN), } \\
\text { Kg/day } \\
\end{array}$ & $\begin{array}{c}\text { Unionized } \\
\text { Ammonia } \\
\text { Nitrogen } \\
\left(\mathrm{NH}_{3}\right), \\
\mathrm{mg} / \mathrm{L} \\
\end{array}$ & $\begin{array}{c}\text { Influent } \\
\text { Nitrate } \\
\text { Nitrogen } \\
\left(\mathrm{NO}_{3}\right), \\
\mathrm{mg} / \mathrm{L} \\
\end{array}$ & $\begin{array}{c}\text { Influent } \\
\text { Nitrate } \\
\text { Nitrogen } \\
\left(\mathrm{NO}_{3}\right) \text {, } \\
\mathrm{kg} / \text { day } \\
\end{array}$ & $\begin{array}{c}\text { Nitrate } \\
\text { Nitrogen } \\
\left(\mathrm{NO}_{3}\right), \\
\mathrm{mg} / \mathrm{L} \\
\end{array}$ \\
\hline $11 / 10 / 00$ & 0.00070 & 0.172 & 0.20 & 0.00161 & 0.476 & 0.542 & 0.5102 \\
\hline $1 / 4 / 01$ & 0.00228 & 0.191 & 0.66 & 0.00447 & 0.65 & 2.246 & 0.715 \\
\hline $3 / 26 / 01$ & 0.00003 & 0.005 & 0.02 & 0.00002 & 0.937 & 4.576 & 0.942 \\
\hline $5 / 16 / 01$ & 0.00005 & 0.063 & 0.53 & 0.00030 & 0.492 & 4.132 & 0.503 \\
\hline $7 / 5 / 01$ & 0.00057 & 0.136 & 0.61 & 0.00031 & 0.473 & 2.124 & 0.514 \\
\hline $8 / 8 / 01$ & 0.00019 & 0.08 & 0.59 & 0.00131 & $2.03 *$ & & 0.64 \\
\hline 9/25/01 & 0.00002 & 0.005 & 0.02 & 0.00003 & 0.6249 & 2.800 & 0.6097 \\
\hline $11 / 19 / 01$ & 0.00005 & 0.05 & 0.13 & 0.00069 & 0.4884 & 1.278 & 0.5871 \\
\hline $6 / 6 / 02$ & 0.00017 & 0.11 & 0.20 & 0.00047 & 0.5200 & 0.941 & 0.5200 \\
\hline $10 / 13 / 02$ & 0.00048 & 0.21 & 0.64 & 0.00159 & 0.9000 & 2.737 & 0.96 \\
\hline Min. & 0.00002 & 0.01 & 0.02 & 0.00002 & 0.47 & 0.54 & 0.50 \\
\hline Max. & 0.00228 & 0.21 & 0.66 & 0.00447 & 0.94 & 4.58 & 0.96 \\
\hline Avg. & 0.00045 & 0.10 & 0.36 & 0.00108 & 0.62 & 2.38 & 0.65 \\
\hline
\end{tabular}


Table B.5. Facility $\mathrm{B} \mathrm{NO}_{3}, \mathrm{NO}_{2}$, and TP.

\begin{tabular}{|c|c|c|c|c|c|c|}
\hline Date & $\begin{array}{c}\text { Nitrate } \\
\text { Nitrogen } \\
\left(\mathrm{NO}_{3}\right) \text {, } \\
\mathrm{Kg} \text { /day } \\
\end{array}$ & $\begin{array}{c}\text { Influent } \\
\text { Nitrite } \\
\text { Nitrogen } \\
\left(\mathrm{NO}_{2}\right) \text {, } \\
\mathrm{mg} / \mathrm{L} \\
\end{array}$ & $\begin{array}{c}\text { Nitrite } \\
\text { Nitrogen } \\
\left(\mathrm{NO}_{2}\right), \\
\mathrm{mg} / \mathrm{L} \\
\end{array}$ & $\begin{array}{c}\text { Nitrite } \\
\text { Nitrogen } \\
\left(\mathrm{NO}_{2}\right) \text {, } \\
\mathrm{Kg} \text { /day } \\
\end{array}$ & $\begin{array}{c}\text { Influent } \\
\text { Total } \\
\text { Phosphorus } \\
\text { (TP), mg/L }\end{array}$ & $\begin{array}{c}\text { Influent } \\
\text { Total } \\
\text { Phosphorus } \\
\text { (TP), } \\
\text { kg/day } \\
\end{array}$ \\
\hline $11 / 10 / 00$ & 0.58 & 0.01 & 0.01 & 0.01 & 0.0005 & 0.001 \\
\hline $1 / 4 / 01$ & 2.47 & 0.01 & 0.01 & 0.03 & 0.0005 & 0.002 \\
\hline $3 / 26 / 01$ & 4.60 & 0.01 & 0.01 & 0.05 & 0.0005 & 0.002 \\
\hline $5 / 16 / 01$ & 4.22 & 0.01 & 0.01 & 0.08 & 0.00501 & 0.042 \\
\hline $7 / 5 / 01$ & 2.31 & 0.01 & 0.01 & 0.04 & 0.0085 & 0.038 \\
\hline $8 / 8 / 01$ & 4.70 & 0.01 & 0.01 & 0.07 & 0.00929 & 0.068 \\
\hline $9 / 25 / 01$ & 2.73 & 0.01 & 0.01 & 0.04 & 0.0250 & 0.112 \\
\hline $11 / 19 / 01$ & 1.54 & 0.01 & 0.01 & 0.03 & 0.03700 & 0.097 \\
\hline $6 / 6 / 02$ & 0.94 & 0.01 & 0.01 & 0.02 & 0.03 & 0.051 \\
\hline $10 / 13 / 02$ & 2.92 & 0.01 & 0.01 & 0.03 & 0.046 & 0.140 \\
\hline Min. & 0.58 & 0.01 & 0.01 & 0.01 & 0.00 & 0.00 \\
\hline Max. & 4.70 & 0.01 & 0.01 & 0.08 & 0.05 & 0.14 \\
\hline Avg. & 2.70 & 0.01 & 0.01 & 0.04 & 0.02 & 0.06 \\
\hline
\end{tabular}

Table B.6. Facility B TP, and $\mathrm{BOD}_{5}$.

\begin{tabular}{cccccc}
\hline & $\begin{array}{c}\text { Total } \\
\text { Phosphorus } \\
(\mathrm{TP}),\end{array}$ & $\begin{array}{c}\text { Total } \\
\text { Phosphorus } \\
(\mathrm{TP}), \\
\mathrm{mg} / \mathrm{L}\end{array}$ & $\begin{array}{c}\text { Influent } \\
\text { Biochemical } \\
\text { Oxygen } \\
\text { Demand } \\
\left(\mathrm{BOD}_{5}\right), \\
\mathrm{mg} / \mathrm{L}\end{array}$ & $\begin{array}{c}\text { Biochemical } \\
\text { Oxygen } \\
\text { Demand } \\
\left(\mathrm{BOD}_{5}\right), \\
\mathrm{mg} / \mathrm{L}\end{array}$ & $\begin{array}{c}\text { Biochemical } \\
\text { Oxygen } \\
\text { Demand } \\
\left(\mathrm{BOD}_{5}\right), \\
\mathrm{Kg} / \text { day }\end{array}$ \\
\hline $11 / 10 / 00$ & 0.0005 & 0.001 & 1.43 & 1.43 & 1.63 \\
$1 / 4 / 01$ & 0.0005 & 0.002 & 1.43 & 1.43 & 4.94 \\
$3 / 26 / 01$ & 0.0005 & 0.002 & 1.43 & 1.43 & 6.98 \\
$5 / 16 / 01$ & 0.0132 & 0.11 & 1.43 & 1.43 & 12.01 \\
$7 / 5 / 01$ & 0.0121 & 0.05 & 1.43 & 1.43 & 6.42 \\
$8 / 8 / 01$ & 0.02217 & 0.16 & 1.43 & 1.43 & 10.50 \\
$9 / 25 / 01$ & 0.061 & 0.27 & 1.43 & 1.43 & 6.41 \\
$11 / 19 / 01$ & 0.092 & 0.24 & 1.43 & 1.43 & 3.74 \\
$6 / 6 / 02$ & 0.041 & 0.07 & 1.43 & 1.43 & 2.59 \\
$10 / 13 / 02$ & 0.088 & 0.27 & 1.43 & 1.43 & 4.35 \\
\hline Min. & 0.001 & 0.001 & 1.43 & 1.43 & 1.63 \\
Max. & 0.09 & 0.27 & 1.43 & 1.43 & 12.01 \\
Avg. & 0.03 & 0.12 & 1.43 & 1.43 & 5.96
\end{tabular}




\section{APPENDIX C}

Table C.1. Facility C Flow, pH, and Temperature.

\begin{tabular}{rcccccc}
\multicolumn{1}{c}{ Date } & $\begin{array}{c}\text { Flow, } \\
\text { gal./min. }\end{array}$ & $\begin{array}{c}\text { Flow, } \\
\text { m3/day }\end{array}$ & $\begin{array}{c}\text { Influent } \\
\mathrm{pH}\end{array}$ & $\mathrm{pH}$ & $\begin{array}{c}\text { Influent } \\
\text { Temperature, } \\
{ }^{\circ} \mathrm{C}\end{array}$ & $\begin{array}{c}\text { Temperature, } \\
{ }^{\circ} \mathrm{C}\end{array}$ \\
\hline $11 / 9 / 00$ & 480 & 2616.19 & 7.24 & 8.84 & 14.3 & 13.2 \\
$1 / 4 / 01$ & 223 & 1215.44 & 8.41 & 8.6 & 11.2 & 12 \\
$3 / 26 / 01$ & 302 & 1646.02 & 8.15 & 8.69 & 11.9 & 11.4 \\
$5 / 16 / 01$ & 337 & 1836.78 & 7.80 & 8.36 & 14.5 & 14.6 \\
$7 / 5 / 01$ & 361 & 1967.59 & 7.68 & 7.96 & 16 & 18.7 \\
$8 / 8 / 01$ & 194 & 1057.38 & 7.98 & 8.26 & 16.3 & 19.7 \\
$9 / 25 / 01$ & 333 & 1814.98 & 7.93 & 8.14 & 14.9 & 15.9 \\
$11 / 19 / 01$ & 303 & 1651.47 & 8.02 & 7.55 & 14.5 & 13.2 \\
$6 / 6 / 02$ & 317 & 1727.78 & 7.66 & 7.02 & 15.6 & 17.8 \\
$10 / 13 / 02$ & 353 & 1923.99 & 7.27 & 6.86 & 15.6 & 16.2 \\
\hline Min. & 194.00 & 1057.38 & 7.24 & 6.86 & 11.20 & 11.40 \\
Max. & 480.00 & 2616.19 & 8.41 & 8.84 & 16.30 & 19.70 \\
Avg. & 320.30 & 1745.76 & 7.81 & 8.03 & 14.48 & 15.27
\end{tabular}

Table C.2. Facility C DO, Turbidity, and Specific Conductance.

\begin{tabular}{rcccccc} 
Date & $\begin{array}{c}\text { Influent } \\
\text { Dissolved } \\
\text { Oxygen, } \\
\text { mg/L }\end{array}$ & $\begin{array}{c}\text { Dissolved } \\
\text { Oxygen, } \\
\text { mg/L }\end{array}$ & $\begin{array}{c}\text { Influent } \\
\text { Turbidity, } \\
\text { NTU }\end{array}$ & $\begin{array}{c}\text { Turbidity, } \\
\text { NTU }\end{array}$ & $\begin{array}{c}\text { Influent } \\
\text { Specific } \\
\text { Conductance, } \\
\mu \mathrm{S} / \mathrm{cm}\end{array}$ & $\begin{array}{c}\text { Specific } \\
\text { Conductance, } \\
\mu \mathrm{S} / \mathrm{cm}\end{array}$ \\
\hline $11 / 9 / 00$ & 9.15 & 12.15 & 0.46 & 15.8 & 143.2 & 189 \\
$1 / 4 / 01$ & 10.61 & 10.35 & 0.74 & 2.66 & 194.6 & 195 \\
$3 / 26 / 01$ & 9.38 & 12.13 & 1.12 & 6.52 & 189.7 & 168.7 \\
$5 / 16 / 01$ & 9.52 & 12.67 & 0.68 & 2.26 & 191.5 & 189.7 \\
$7 / 5 / 01$ & 9.42 & 10.36 & 0.5 & 8.33 & 192.4 & 195 \\
$8 / 8 / 01$ & 8.93 & 10.42 & 0.66 & 4.64 & 195.2 & 194.6 \\
$9 / 25 / 01$ & 9.99 & 11.9 & 1 & 2.73 & 197.2 & 197.4 \\
$11 / 19 / 01$ & 9.6 & 10.27 & 2.21 & 4.7 & 198.6 & 202.8 \\
$6 / 6 / 02$ & 9.34 & 6.01 & 0.86 & 0.96 & 200 & 204.2 \\
$10 / 13 / 02$ & 8.39 & 7.89 & 0.77 & 2.06 & 200 & 202.8 \\
\hline Min. & 8.39 & 6.01 & 0.46 & 0.96 & 143.20 & 168.70 \\
Max. & 10.61 & 12.67 & 2.21 & 15.80 & 200.00 & 204.20 \\
Avg. & 9.43 & 10.42 & 0.90 & 5.07 & 190.24 & 193.92
\end{tabular}


Table C.3. Facility C TSS and TAN.

\begin{tabular}{rcccccc}
\hline & $\begin{array}{c}\text { Influent } \\
\text { Total } \\
\text { Suspended } \\
\text { Solids } \\
\text { (TSS), }\end{array}$ & $\begin{array}{c}\text { Influent } \\
\text { Total } \\
\text { Suspended } \\
\text { Solids } \\
\text { (TSS), }\end{array}$ & $\begin{array}{c}\text { Total } \\
\text { Suspended } \\
\text { Solids } \\
\text { (TSS), }\end{array}$ & $\begin{array}{c}\text { Total } \\
\text { Suspended } \\
\text { Solids } \\
\text { (TSS), }\end{array}$ & $\begin{array}{c}\text { Influent } \\
\text { Ammonia } \\
\text { Nitrogen } \\
\text { (TAN), } \\
\text { Date }\end{array}$ & $\begin{array}{c}\text { Influent } \\
\text { Ammonia } \\
\text { Nitrogen } \\
\text { (TAN), } \\
\text { kg/day }\end{array}$ \\
\hline $11 / 9 / 00$ & 2 & 5.23 & 8 & 20.93 & 0.158 & 0.413 \\
$1 / 4 / 01$ & 2.5 & 3.04 & 10 & 12.15 & 0.178 & 0.216 \\
$3 / 26 / 01$ & 3 & 4.94 & 14 & 23.04 & 0.005 & 0.008 \\
$5 / 16 / 01$ & 2 & 3.67 & 6 & 11.02 & 0.041 & 0.075 \\
$7 / 5 / 01$ & 2 & 3.94 & 12.7 & 24.99 & 0.153 & 0.301 \\
$8 / 8 / 01$ & 2 & 2.11 & 2 & 2.11 & 0.01 & 0.011 \\
$9 / 25 / 01$ & 6 & 10.89 & 3.5 & 6.35 & 0.01 & 0.018 \\
$11 / 19 / 01$ & 2 & 3.30 & 2 & 3.30 & 0.005 & 0.008 \\
$6 / 6 / 02$ & 2 & 3.46 & 3.5 & 6.05 & 0.14 & 0.242 \\
$10 / 13 / 02$ & 3 & 5.77 & 7 & 13.47 & 0.17 & 0.327 \\
\hline Min. & 2.00 & 2.11 & 2.00 & 2.11 & 0.01 & 0.01 \\
Max. & 6.00 & 10.89 & 14.00 & 24.99 & 0.18 & 0.41 \\
Avg. & 2.65 & 4.64 & 6.87 & 12.34 & 0.09 & 0.16
\end{tabular}

Table C.4. Facility $\mathrm{C} \mathrm{NH}_{3}$, TAN, and $\mathrm{NO}_{3}$.

\begin{tabular}{|c|c|c|c|c|c|c|c|}
\hline Date & $\begin{array}{c}\text { Influent } \\
\text { Unionized } \\
\text { Ammonia } \\
\text { Nitrogen } \\
\left(\mathrm{NH}_{3}\right), \\
\mathrm{mg} / \mathrm{L} \\
\end{array}$ & $\begin{array}{c}\text { Ammonia } \\
\text { Nitrogen } \\
\text { (TAN), } \\
\text { mg/L }\end{array}$ & $\begin{array}{c}\text { Ammonia } \\
\text { Nitrogen } \\
\text { (TAN), } \\
\text { Kg/day } \\
\end{array}$ & $\begin{array}{c}\text { Unionized } \\
\text { Ammonia } \\
\text { Nitrogen } \\
\left(\mathrm{NH}_{3}\right) \\
\mathrm{mg} / \mathrm{L} \\
\end{array}$ & $\begin{array}{c}\text { Influent } \\
\text { Nitrate } \\
\text { Nitrogen } \\
\left(\mathrm{NO}_{3}\right) \text {, } \\
\mathrm{mg} / \mathrm{L} \\
\end{array}$ & $\begin{array}{c}\text { Influent } \\
\text { Nitrate } \\
\text { Nitrogen } \\
\left(\mathrm{NO}_{3}\right) \text {, } \\
\mathrm{kg} / \text { day } \\
\end{array}$ & $\begin{array}{c}\text { Nitrate } \\
\text { Nitrogen } \\
\left(\mathrm{NO}_{3}\right), \\
\mathrm{mg} / \mathrm{L} \\
\end{array}$ \\
\hline $11 / 9 / 00$ & 0.00071 & 0.134 & 0.35 & 0.01893 & 0.069 & 0.181 & 0.051 \\
\hline $1 / 4 / 01$ & 0.00886 & 0.184 & 0.22 & 0.01462 & 0.107 & 0.130 & 0.116 \\
\hline $3 / 26 / 01$ & 0.00015 & 0.075 & 0.12 & 0.00690 & 0.05 & 0.087 & 0.02 \\
\hline $5 / 16 / 01$ & 0.00067 & 0.109 & 0.20 & 0.00623 & 0.047 & 0.086 & 0.031 \\
\hline $7 / 5 / 01$ & 0.00212 & 0.21 & 0.41 & 0.00667 & 0.01 & 0.020 & 0.03 \\
\hline $8 / 8 / 01$ & 0.00028 & 0.15 & 0.16 & 0.00987 & 0.265 & 0.280 & 0.029 \\
\hline $9 / 25 / 01$ & 0.00023 & 0.3 & 0.54 & 0.01162 & 0.1411 & 0.256 & 0.1479 \\
\hline $11 / 19 / 01$ & 0.00013 & 0.45 & 0.74 & 0.00377 & 0.5455 & 0.901 & 0.1108 \\
\hline $6 / 6 / 02$ & 0.00180 & 0.26 & 0.45 & 0.00091 & 0.05 & 0.086 & 0.07 \\
\hline $10 / 13 / 02$ & 0.00090 & 0.25 & 0.48 & 0.00054 & 0.08 & 0.154 & 0.07 \\
\hline Min. & 0.00013 & 0.08 & 0.12 & 0.00054 & 0.01 & 0.02 & 0.02 \\
\hline Max. & 0.00886 & 0.45 & 0.74 & 0.01893 & 0.55 & 0.90 & 0.15 \\
\hline Avg. & 0.00158 & 0.21 & 0.37 & 0.00801 & 0.14 & 0.22 & 0.07 \\
\hline
\end{tabular}


Table C.5. Facility $\mathrm{C} \mathrm{NO}_{3}, \mathrm{NO}_{2}$, and TP.

\begin{tabular}{|c|c|c|c|c|c|c|}
\hline Date & $\begin{array}{c}\text { Nitrate } \\
\text { Nitrogen } \\
\left(\mathrm{NO}_{3}\right), \\
\mathrm{Kg} \text { /day } \\
\end{array}$ & $\begin{array}{l}\text { Influent } \\
\text { Nitrite } \\
\text { Nitrogen } \\
\left(\mathrm{NO}_{2}\right) \text {, } \\
\mathrm{mg} / \mathrm{L} \\
\end{array}$ & $\begin{array}{c}\text { Nitrite } \\
\text { Nitrogen } \\
\left(\mathrm{NO}_{2}\right), \\
\mathrm{mg} / \mathrm{L} \\
\end{array}$ & $\begin{array}{c}\text { Nitrite } \\
\text { Nitrogen } \\
\left(\mathrm{NO}_{2}\right) \text {, } \\
\mathrm{Kg} \text { day }\end{array}$ & $\begin{array}{c}\text { Influent } \\
\text { Total } \\
\text { Phosphorus } \\
\text { (TP), mg/L }\end{array}$ & $\begin{array}{c}\text { Influent } \\
\text { Total } \\
\text { Phosphorus } \\
\text { (TP), } \\
\text { kg/day } \\
\end{array}$ \\
\hline $11 / 9 / 00$ & 0.13 & 0.01 & 0.01 & 0.03 & 0.0005 & 0.001 \\
\hline $1 / 4 / 01$ & 0.14 & 0.01 & 0.01 & 0.01 & 0.0005 & 0.001 \\
\hline $3 / 26 / 01$ & 0.03 & 0.01 & 0.01 & 0.02 & 0.0189 & 0.031 \\
\hline $5 / 16 / 01$ & 0.06 & 0.01 & 0.01 & 0.02 & 0.05240 & 0.096 \\
\hline $7 / 5 / 01$ & 0.06 & 0.01 & 0.01 & 0.02 & 0.0376 & 0.074 \\
\hline $8 / 8 / 01$ & 0.03 & 0.01 & 0.01 & 0.01 & 0.05258 & 0.056 \\
\hline $9 / 25 / 01$ & 0.27 & 0.01 & 0.01 & 0.02 & 0.07 & 0.131 \\
\hline $11 / 19 / 01$ & 0.18 & 0.01 & 0.01 & 0.02 & 0.082 & 0.135 \\
\hline $6 / 6 / 02$ & 0.12 & 0.01 & 0.01 & 0.02 & 0.038 & 0.066 \\
\hline $10 / 13 / 02$ & 0.13 & 0.01 & 0.01 & 0.02 & 0.162 & 0.312 \\
\hline Min. & 0.03 & 0.01 & 0.01 & 0.01 & 0.00 & 0.00 \\
\hline Max. & 0.27 & 0.01 & 0.01 & 0.03 & 0.16 & 0.31 \\
\hline Avg. & 0.12 & 0.01 & 0.01 & 0.02 & 0.05 & 0.09 \\
\hline
\end{tabular}

Table C.6. Facility C TP, and BOD . $^{\text {. }}$

\begin{tabular}{|c|c|c|c|c|c|c|}
\hline Date & $\begin{array}{c}\text { Total } \\
\text { Phosphorus } \\
(\mathrm{TP}), \\
\mathrm{mg} / \mathrm{L} \\
\end{array}$ & $\begin{array}{c}\text { Total } \\
\text { Phosphorus } \\
\text { (TP), } \\
\text { Kg/day } \\
\end{array}$ & $\begin{array}{c}\text { Influent } \\
\text { Biochemical } \\
\text { Oxygen } \\
\text { Demand } \\
\left(\mathrm{BOD}_{5}\right) \text {, } \\
\mathrm{mg} / \mathrm{L} \\
\end{array}$ & $\begin{array}{c}\text { Influent } \\
\text { Biochemical } \\
\text { Oxygen } \\
\text { Demand } \\
\left(\mathrm{BOD}_{5}\right) \\
\text { kg/day } \\
\end{array}$ & $\begin{array}{c}\text { Biochemical } \\
\text { Oxygen } \\
\text { Demand } \\
\left(\mathrm{BOD}_{5}\right), \\
\mathrm{mg} / \mathrm{L} \\
\end{array}$ & $\begin{array}{c}\text { Biochemical } \\
\text { Oxygen } \\
\text { Demand } \\
\left(\mathrm{BOD}_{5}\right), \\
\mathrm{Kg} / \text { day } \\
\end{array}$ \\
\hline $11 / 9 / 00$ & 0.0005 & 0.001 & 1.43 & 3.74 & 1.43 & 3.74 \\
\hline $1 / 4 / 01$ & 0.0005 & 0.001 & 1.43 & 1.74 & 1.43 & 1.74 \\
\hline $3 / 26 / 01$ & 0.069 & 0.11 & 1.43 & 2.35 & 4.27 & 7.03 \\
\hline $5 / 16 / 01$ & 0.0684 & 0.13 & 1.43 & 2.63 & 1.43 & 2.63 \\
\hline $7 / 5 / 01$ & 0.05258 & 0.10 & 1.43 & 2.81 & 1.43 & 2.81 \\
\hline $8 / 8 / 01$ & 0.06287 & 0.07 & 1.43 & 1.51 & 1.43 & 1.51 \\
\hline $9 / 25 / 01$ & 0.104 & 0.19 & 1.43 & 2.60 & 1.43 & 2.60 \\
\hline $11 / 19 / 01$ & 0.127 & 0.21 & 1.43 & 2.36 & 1.43 & 2.36 \\
\hline $6 / 6 / 02$ & 0.118 & 0.20 & 1.43 & 2.47 & 1.43 & 2.47 \\
\hline $10 / 13 / 02$ & 0.256 & 0.49 & 1.43 & 2.75 & 1.43 & 2.75 \\
\hline Min. & 0.00 & 0.00 & 1.43 & 1.51 & 1.43 & 1.51 \\
\hline Max. & 0.26 & 0.49 & 1.43 & 3.74 & 4.27 & 7.03 \\
\hline Avg. & 0.09 & 0.15 & 1.43 & 2.50 & 1.71 & 2.96 \\
\hline
\end{tabular}




\section{APPENDIX D}

Table D.1. Facility D Flow, pH, and Temperature.

\begin{tabular}{ccccccc} 
Date & $\begin{array}{c}\text { Flow, } \\
\text { gal./min. }\end{array}$ & $\begin{array}{c}\text { Flow, } \\
\mathrm{m} 3 / \text { day }\end{array}$ & $\begin{array}{c}\text { Influent } \\
\mathrm{pH}\end{array}$ & $\mathrm{pH}$ & $\begin{array}{c}\text { Influent } \\
\text { Temperature, } \\
{ }^{\circ} \mathrm{C}\end{array}$ & $\begin{array}{c}\text { Temperature, } \\
{ }^{\circ} \mathrm{C}\end{array}$ \\
\hline $1 / 17 / 01$ & 171 & 932.02 & 7.92 & 7.83 & 9.3 & 10.9 \\
$2 / 22 / 01$ & 412 & 2245.56 & 8.06 & 7.92 & 9.8 & 10.3 \\
$5 / 14 / 01$ & 751 & 4093.25 & 7.45 & 7.46 & 11.1 & 12.7 \\
$7 / 2 / 01$ & 808 & 4403.92 & 7.81 & 8.06 & 11.8 & 13.3 \\
$8 / 6 / 01$ & 950 & 5177.88 & 7.68 & 8.48 & 13 & 13.1 \\
$10 / 2 / 01$ & 378 & 2060.25 & 7.70 & 7.72 & 12.1 & 12.7 \\
$12 / 4 / 01$ & 178 & 970.17 & 7.65 & 7.74 & 11.7 & 11.6 \\
$6 / 26 / 02$ & 376 & 2049.35 & 7.25 & 7.26 & 11.8 & 13.2 \\
\hline Min. & 171.00 & 932.02 & 7.25 & 7.26 & 9.30 & 10.30 \\
Max. & 950.00 & 5177.88 & 8.06 & 8.48 & 13.00 & 13.30 \\
Avg. & 503.00 & 2741.55 & 7.69 & 7.81 & 11.33 & 12.23
\end{tabular}

Table D.2. Facility D DO, Turbidity, and Specific Conductance.

\begin{tabular}{ccccccc} 
Date & $\begin{array}{c}\text { Influent } \\
\text { Dissolved } \\
\text { Oxygen, } \\
\mathrm{mg} / \mathrm{L}\end{array}$ & $\begin{array}{c}\text { Dissolved } \\
\text { Oxygen, } \\
\mathrm{mg} / \mathrm{L}\end{array}$ & $\begin{array}{c}\text { Influent } \\
\text { Turbidity, } \\
\text { NTU }\end{array}$ & $\begin{array}{c}\text { Influent } \\
\text { Turbidity, } \\
\text { NTU }\end{array}$ & $\begin{array}{c}\text { Specific } \\
\text { Conductance, } \\
\mu \mathrm{S} / \mathrm{cm}\end{array}$ & $\begin{array}{c}\text { Specific } \\
\text { Conductance, } \\
\mu \mathrm{S} / \mathrm{cm}\end{array}$ \\
\hline $1 / 17 / 01$ & 6.48 & 6.22 & 3.81 & 3.81 & 300 & 300 \\
$2 / 22 / 01$ & 9.15 & 9.07 & 1.03 & 2.02 & 222.7 & 222.1 \\
$5 / 14 / 01$ & 9.6 & 7.57 & 3.05 & 3.87 & 283.2 & 285.6 \\
$7 / 2 / 01$ & 9.95 & 9.12 & 2.75 & 5.11 & 302 & 306.4 \\
$8 / 6 / 01$ & 9.86 & 10.16 & 7.47 & 8.13 & 193.6 & 260.7 \\
$10 / 2 / 01$ & 9.48 & 8.17 & 4.08 & 5.37 & 323 & 325.2 \\
$12 / 4 / 01$ & 8.95 & 5.96 & 2.19 & 4.75 & 238.7 & 336.1 \\
$6 / 26 / 02$ & 11.19 & 8.28 & 1.82 & 2.54 & 306.3 & 311.3 \\
\hline Min. & 6.48 & 5.96 & 1.03 & 2.02 & 193.60 & 222.10 \\
Max. & 11.19 & 10.16 & 7.47 & 8.13 & 323.00 & 336.10 \\
Avg. & 9.33 & 8.07 & 3.28 & 4.45 & 271.19 & 293.43
\end{tabular}


Table D.3. Facility D TSS and TAN.

\begin{tabular}{|c|c|c|c|c|c|c|}
\hline Date & $\begin{array}{c}\text { Influent Total } \\
\text { Suspended } \\
\text { Solids (TSS), } \\
\text { mg/L } \\
\end{array}$ & $\begin{array}{c}\text { Influent Total } \\
\text { Suspended } \\
\text { Solids (TSS), } \\
\text { kg/day } \\
\end{array}$ & $\begin{array}{c}\text { Total } \\
\text { Suspended } \\
\text { Solids } \\
\text { (TSS), } \\
\mathrm{mg} / \mathrm{L} \\
\end{array}$ & $\begin{array}{c}\text { Total } \\
\text { Suspended } \\
\text { Solids } \\
\text { (TSS), } \\
\text { kg/day } \\
\end{array}$ & $\begin{array}{c}\text { Influent } \\
\text { Ammonia } \\
\text { Nitrogen } \\
\text { (TAN), mg/L } \\
\end{array}$ & $\begin{array}{c}\text { Influent } \\
\text { Ammonia } \\
\text { Nitrogen } \\
\text { (TAN), kg/day }\end{array}$ \\
\hline $1 / 17 / 01$ & 3 & 2.796 & 9 & 8.39 & 0.025 & 0.0233 \\
\hline $2 / 22 / 01$ & 2 & 4.491 & 7 & 15.72 & 0.035 & 0.0786 \\
\hline $5 / 14 / 01$ & 1 & 4.093 & 11 & 45.03 & 0.041 & 0.1678 \\
\hline $7 / 2 / 01$ & 0.5 & 2.202 & 25 & 110.10 & 0.152 & 0.6694 \\
\hline $8 / 6 / 01$ & 8 & 41.423 & 14.5 & 75.08 & 0.02 & 0.1036 \\
\hline $10 / 2 / 01$ & 2 & 4.121 & 8 & 16.48 & 0.01 & 0.0206 \\
\hline $12 / 4 / 01$ & 4 & 3.881 & 7 & 6.79 & 0.005 & 0.0049 \\
\hline $6 / 26 / 02$ & 3.5 & 7.173 & 5.5 & 11.27 & 0.1384 & 0.2836 \\
\hline Min. & 0.50 & 2.20 & 5.50 & 6.79 & 0.005 & 0.005 \\
\hline Max. & 8.00 & 41.42 & 25.00 & 110.10 & 0.15 & 0.67 \\
\hline Avg. & 3.00 & 8.77 & 10.88 & 36.11 & 0.05 & 0.17 \\
\hline
\end{tabular}

Table D.4. Facility D NH

\begin{tabular}{|c|c|c|c|c|c|c|c|}
\hline Date & $\begin{array}{c}\text { Influent } \\
\text { Unionized } \\
\text { Ammonia } \\
\text { Nitrogen } \\
\left(\mathrm{NH}_{3}\right), \mathrm{mg} / \mathrm{L} \\
\end{array}$ & $\begin{array}{c}\text { Ammonia } \\
\text { Nitrogen } \\
\text { (TAN), } \\
\text { mg/L } \\
\end{array}$ & $\begin{array}{c}\text { Ammonia } \\
\text { Nitrogen } \\
\text { (TAN), } \\
\text { Kg/day }\end{array}$ & $\begin{array}{c}\text { Unionized } \\
\text { Ammonia } \\
\text { Nitrogen } \\
\left(\mathrm{NH}_{3}\right) \\
\mathrm{mg} / \mathrm{L} \\
\end{array}$ & $\begin{array}{c}\text { Influent } \\
\text { Nitrate } \\
\text { Nitrogen } \\
\left(\mathrm{NO}_{3}\right) \text {, } \\
\mathrm{mg} / \mathrm{L} \\
\end{array}$ & $\begin{array}{c}\text { Influent } \\
\text { Nitrate } \\
\text { Nitrogen } \\
\left(\mathrm{NO}_{3}\right) \text {, } \\
\mathrm{kg} / \text { day } \\
\end{array}$ & $\begin{array}{c}\text { Nitrate } \\
\text { Nitrogen } \\
\left(\mathrm{NO}_{3}\right), \\
\mathrm{mg} / \mathrm{L} \\
\end{array}$ \\
\hline $1 / 17 / 01$ & 0.00036 & 0.11 & 0.10 & 0.00146 & 1.02 & 0.951 & 1.44 \\
\hline $2 / 22 / 01$ & 0.00072 & 0.102 & 0.23 & 0.00159 & 1.37 & 3.076 & 1.36 \\
\hline $5 / 14 / 01$ & 0.00023 & 0.17 & 0.70 & 0.00111 & 1.09 & 4.462 & 1.10 \\
\hline $7 / 2 / 01$ & 0.00207 & 0.232 & 1.02 & 0.00621 & 1.04 & 4.580 & 1.06 \\
\hline $8 / 6 / 01$ & 0.00022 & 0.1 & 0.52 & 0.00665 & 1.01 & 5.230 & 0.996 \\
\hline $10 / 2 / 01$ & 0.00011 & 0.17 & 0.35 & 0.00202 & 1.2548 & 2.585 & 1.2055 \\
\hline $12 / 4 / 01$ & 0.00005 & 0.59 & 0.57 & 0.00674 & 1.1428 & 1.109 & 0.7167 \\
\hline $6 / 26 / 02$ & 0.00052 & 0.3411 & 0.70 & 0.00147 & 0.10 & 0.205 & 0.12 \\
\hline Min. & 0.000047 & 0.10 & 0.10 & 0.001115 & 0.10 & 0.20 & 0.12 \\
\hline Max. & 0.002067 & 0.59 & 1.02 & 0.006739 & 1.37 & 5.23 & 1.44 \\
\hline Avg. & 0.000535 & 0.23 & 0.52 & 0.003407 & 1.00 & 2.77 & 1.00 \\
\hline
\end{tabular}


Table D.5. Facility D NO $3, \mathrm{NO}_{2}$, and TP.

\begin{tabular}{ccccccc} 
Nitrate & $\begin{array}{c}\text { Influent } \\
\text { Nitrite } \\
\left(\mathrm{NO}_{3}\right), \\
\mathrm{Kg} / \text { day }\end{array}$ & $\begin{array}{c}\text { Nitrogen } \\
\left(\mathrm{NO}_{2}\right), \\
\mathrm{mg} / \mathrm{L}\end{array}$ & $\begin{array}{c}\text { Nitrite } \\
\text { Nitrogen } \\
\left(\mathrm{NO}_{2}\right), \\
\mathrm{mg} / \mathrm{L}\end{array}$ & $\begin{array}{c}\text { Nitrite } \\
\text { Nitrogen } \\
\left(\mathrm{NO}_{2}\right), \\
\mathrm{Kg} / \text { day }\end{array}$ & $\begin{array}{c}\text { Influent Total } \\
\text { Phosphorus } \\
(\mathrm{TP}), \mathrm{mg} / \mathrm{L}\end{array}$ & $\begin{array}{c}\text { Influent Total } \\
\text { Phosphorus } \\
(\mathrm{TP}), \mathrm{kg} / \text { day }\end{array}$ \\
\hline $1 / 17 / 01$ & 1.34 & 0.01 & 0.01 & 0.01 & 0.0005 & 0.0005 \\
$2 / 22 / 01$ & 3.05 & 0.01 & 0.01 & 0.02 & 0.0005 & 0.0011 \\
$5 / 14 / 01$ & 4.50 & 0.01 & 0.01 & 0.04 & 0.00988 & 0.0404 \\
$7 / 2 / 01$ & 4.67 & 0.01 & 0.01 & 0.04 & 0.00999 & 0.0440 \\
$8 / 6 / 01$ & 5.16 & 0.01 & 0.01 & 0.05 & 0.01343 & 0.0695 \\
$10 / 2 / 01$ & 2.48 & 0.01 & 0.01 & 0.02 & 0.039 & 0.0803 \\
$12 / 4 / 01$ & 0.70 & 0.01 & 0.01 & 0.01 & 0.029 & 0.0281 \\
$6 / 26 / 02$ & 0.25 & 0.01 & 0.01 & 0.02 & 0.024 & 0.0492 \\
\hline Min. & 0.25 & 0.01 & 0.01 & 0.01 & 0.0005 & 0.0005 \\
Max. & 5.16 & 0.01 & 0.01 & 0.05 & 0.039 & 0.080 \\
Avg. & 2.77 & 0.01 & 0.01 & 0.03 & 0.016 & 0.039
\end{tabular}

Table D.6. Facility D TP, and BOD 5 .

\begin{tabular}{|c|c|c|c|c|c|c|}
\hline Date & $\begin{array}{c}\text { Total } \\
\text { Phosphorus } \\
\text { (TP), } \\
\text { mg/L } \\
\end{array}$ & $\begin{array}{c}\text { Total } \\
\text { Phosphorus } \\
\text { (TP), } \\
\text { Kg/day } \\
\end{array}$ & $\begin{array}{c}\text { Influent } \\
\text { Biochemical } \\
\text { Oxygen } \\
\text { Demand } \\
\left(\mathrm{BOD}_{5}\right), \\
\mathrm{mg} / \mathrm{L} \\
\end{array}$ & $\begin{array}{c}\text { Influent } \\
\text { Biochemical } \\
\text { Oxygen } \\
\text { Demand } \\
\left(\mathrm{BOD}_{5}\right) \\
\text { kg/day } \\
\end{array}$ & $\begin{array}{c}\text { Biochemical } \\
\text { Oxygen } \\
\text { Demand } \\
\left(\mathrm{BOD}_{5}\right) \\
\text { mg/L } \\
\end{array}$ & $\begin{array}{c}\text { Biochemical } \\
\text { Oxygen } \\
\text { Demand } \\
\left(\mathrm{BOD}_{5}\right), \\
\mathrm{Kg} / \text { day } \\
\end{array}$ \\
\hline $1 / 17 / 01$ & 0.119 & 0.11 & 1.43 & 1.33 & 1.43 & 1.33 \\
\hline $2 / 22 / 01$ & 0.0499 & 0.11 & 1.43 & 3.21 & 1.43 & 3.21 \\
\hline $5 / 14 / 01$ & 0.0962 & 0.39 & 1.43 & 5.85 & 1.43 & 5.85 \\
\hline $7 / 2 / 01$ & 0.328 & 1.44 & 1.43 & 6.30 & 4.18 & 18.41 \\
\hline $8 / 6 / 01$ & 0.03187 & 0.17 & 1.43 & 7.40 & 1.43 & 7.40 \\
\hline $10 / 2 / 01$ & 0.179 & 0.37 & 1.43 & 2.95 & 1.43 & 2.95 \\
\hline $12 / 4 / 01$ & 0.371 & 0.36 & 1.43 & 1.39 & 4.96 & 4.81 \\
\hline $6 / 26 / 02$ & 0.368 & 0.75 & 1.43 & 2.93 & 3.09 & 6.33 \\
\hline Min. & 0.03 & 0.11 & 1.43 & 1.33 & 1.43 & 1.33 \\
\hline Max. & 0.37 & 1.44 & 1.43 & 7.40 & 4.96 & 18.41 \\
\hline Avg. & 0.19 & 0.46 & 1.43 & 3.92 & 2.42 & 6.29 \\
\hline
\end{tabular}




\section{APPENDIX E}

Table E.1. Facility E Flow, pH, and Temperature.

\begin{tabular}{|c|c|c|c|c|c|c|}
\hline Date & $\begin{array}{l}\text { Flow, } \\
\text { gal./min. }\end{array}$ & $\begin{array}{l}\text { Flow, } \\
\text { m3/day }\end{array}$ & $\begin{array}{c}\text { Influent } \\
\mathrm{Ph}\end{array}$ & $\mathrm{pH}$ & $\begin{array}{c}\text { Influent } \\
\text { Temperature, } \\
{ }^{\circ} \mathrm{C}\end{array}$ & $\begin{array}{c}\text { Temperature, } \\
{ }^{\circ} \mathrm{C}\end{array}$ \\
\hline $1 / 17 / 01$ & 986 & 5374.09 & 7.05 & 7.65 & 13.5 & 13.1 \\
\hline $3 / 1 / 01$ & 2314 & 12612.23 & 6.82 & 7.23 & 13.1 & 12.9 \\
\hline $5 / 14 / 01$ & 2951 & 16084.13 & 6.72 & 7.38 & 13.7 & 14 \\
\hline $7 / 2 / 01$ & 1450 & 7903.08 & 7.05 & 7.68 & 13.5 & 14 \\
\hline $8 / 6 / 01$ & 2346 & 12786.64 & 7.20 & 7.81 & 13.3 & 14 \\
\hline $10 / 2 / 01$ & 1500 & 8175.60 & 6.94 & 7.37 & 13.5 & 13.9 \\
\hline $12 / 4 / 01$ & 1230 & 6703.99 & 7.06 & 7.45 & 13.7 & 13.3 \\
\hline $6 / 26 / 02$ & 2000 & 10900.80 & 6.33 & 6.86 & 13.5 & 14.1 \\
\hline Min. & 986 & 5374.09 & 6.33 & 6.86 & 13.10 & 12.90 \\
\hline Max. & 2951 & 16084.13 & 7.20 & 7.81 & 13.70 & 14.10 \\
\hline Avg. & 1825 & 10067.57 & 6.90 & 7.43 & 13.48 & 13.66 \\
\hline
\end{tabular}

Table E.2. Facility E DO, Turbidity, and Specific Conductance.

\begin{tabular}{rcccccc} 
Influent & $\begin{array}{c}\text { Dissolved } \\
\text { Oxygen, } \\
\text { mg/L }\end{array}$ & $\begin{array}{c}\text { Dissolved } \\
\text { Oxygen, } \\
\text { mg/L }\end{array}$ & $\begin{array}{c}\text { Influent } \\
\text { Turbidity, } \\
\text { NTU }\end{array}$ & $\begin{array}{c}\text { Influent } \\
\text { Theidity, } \\
\text { NTU }\end{array}$ & $\begin{array}{c}\text { Specific } \\
\text { Conductance, } \\
\mu \text { S/cm }\end{array}$ & $\begin{array}{c}\text { Specific } \\
\text { Conductance, } \\
\mu S / c m\end{array}$ \\
\hline $1 / 17 / 01$ & 5.93 & 7.24 & 4.61 & 8.32 & 500 & 500 \\
$3 / 1 / 01$ & 6.21 & 8.2 & 5.11 & 5.44 & 443.6 & 489 \\
$5 / 14 / 01$ & 5.96 & 7.98 & 4.02 & 3.63 & 458.8 & 537 \\
$7 / 2 / 01$ & 5.91 & 7.93 & 3.99 & 6.9 & 472.2 & 477 \\
$8 / 6 / 01$ & 6.22 & 7.98 & 5.28 & 7.12 & 422.8 & 430 \\
$10 / 2 / 01$ & 5.82 & 7.34 & 4.58 & 4.81 & 391.2 & 505 \\
$12 / 4 / 01$ & 6.09 & 5.74 & 4.44 & 3.98 & 545 & 548 \\
$6 / 26 / 02$ & 6.97 & 8.88 & 4.34 & 4.92 & 503 & 509 \\
\hline Min. & 5.82 & 5.74 & 3.99 & 3.63 & 391.20 & 430.00 \\
Max. & 6.97 & 8.88 & 5.28 & 8.32 & 545.00 & 548.00 \\
Avg. & 6.14 & 7.66 & 4.55 & 5.64 & 467.08 & 499.38
\end{tabular}


Table E.3. Facility E TSS and TAN.

\begin{tabular}{|c|c|c|c|c|c|c|}
\hline Date & $\begin{array}{c}\text { Influent } \\
\text { Total } \\
\text { Suspended } \\
\text { Solids } \\
\text { (TSS), } \\
\text { mg/L }\end{array}$ & $\begin{array}{c}\text { Influent } \\
\text { Total } \\
\text { Suspended } \\
\text { Solids } \\
\text { (TSS), } \\
\text { kg/day }\end{array}$ & $\begin{array}{c}\text { Total } \\
\text { Suspended } \\
\text { Solids } \\
\text { (TSS), mg/L }\end{array}$ & $\begin{array}{c}\text { Total } \\
\text { Suspended } \\
\text { Solids (TSS), } \\
\text { kg/day }\end{array}$ & $\begin{array}{c}\text { Influent } \\
\text { Ammonia } \\
\text { Nitrogen } \\
\text { (TAN), } \\
\text { mg/L }\end{array}$ & $\begin{array}{c}\text { Influent } \\
\text { Ammonia } \\
\text { Nitrogen } \\
\text { (TAN), } \\
\text { kg/day }\end{array}$ \\
\hline $1 / 17 / 01$ & 2 & 10.75 & 6 & 32.24 & 0.08 & 0.44 \\
\hline $3 / 1 / 01$ & 1 & 12.61 & 5 & 63.06 & 0.09 & 1.14 \\
\hline $5 / 14 / 01$ & 1 & 16.08 & 10 & 160.84 & 0.078 & 1.25 \\
\hline $7 / 2 / 01$ & 2 & 15.81 & 6.2 & 49.00 & 0.22 & 1.72 \\
\hline $8 / 6 / 01$ & 4 & 51.15 & 10 & 127.87 & 0.09 & 1.15 \\
\hline $10 / 2 / 01$ & 2.5 & 20.44 & 9 & 73.58 & 0.05 & 0.41 \\
\hline $12 / 4 / 01$ & 3 & 20.11 & 10 & 67.04 & 0.07 & 0.47 \\
\hline $6 / 26 / 02$ & 3.5 & 38.15 & 7 & 76.31 & 1.2278 & 13.38 \\
\hline Min. & 1.00 & 10.75 & 5.00 & 32.24 & 0.05 & 0.41 \\
\hline Max. & 4.00 & 51.15 & 10.00 & 160.84 & 1.23 & 13.38 \\
\hline Avg. & 2.38 & 23.14 & 7.90 & 81.24 & 0.24 & 2.50 \\
\hline
\end{tabular}

Table E.4. Facility $\mathrm{E} \mathrm{NH}_{3}$, TAN, and $\mathrm{NO}_{3}$.

\begin{tabular}{|c|c|c|c|c|c|c|c|}
\hline Date & $\begin{array}{c}\text { Influent } \\
\text { Unionized } \\
\text { Ammonia } \\
\text { Nitrogen } \\
\left(\mathrm{NH}_{3}\right), \\
\mathrm{mg} / \mathrm{L}\end{array}$ & $\begin{array}{c}\text { Ammonia } \\
\text { Nitrogen } \\
\text { (TAN), } \\
\text { mg/L }\end{array}$ & $\begin{array}{l}\text { Ammonia } \\
\text { Nitrogen } \\
\text { (TAN), } \\
\text { Kg/day }\end{array}$ & $\begin{array}{c}\text { Unionized } \\
\text { Ammonia } \\
\text { Nitrogen } \\
\left(\mathrm{NH}_{3}\right), \\
\mathrm{mg} / \mathrm{L}\end{array}$ & $\begin{array}{c}\text { Influent } \\
\text { Nitrate } \\
\text { Nitrogen } \\
\left(\mathrm{NO}_{3}\right) \text {, } \\
\mathrm{mg} / \mathrm{L}\end{array}$ & $\begin{array}{c}\text { Influent } \\
\text { Nitrate } \\
\text { Nitrogen } \\
\left(\mathrm{NO}_{3}\right) \text {, } \\
\mathrm{kg} / \text { day }\end{array}$ & $\begin{array}{c}\text { Nitrate } \\
\text { Nitrogen } \\
\left(\mathrm{NO}_{3}\right), \\
\mathrm{mg} / \mathrm{L}\end{array}$ \\
\hline $1 / 17 / 01$ & 0.00022 & 0.211 & 1.13 & 0.00220 & 0.01 & 0.05 & 0.174 \\
\hline $3 / 1 / 01$ & 0.00014 & 0.194 & 2.45 & 0.00076 & 0.105 & 1.32 & 0.196 \\
\hline $5 / 14 / 01$ & 0.00010 & 0.187 & 3.01 & 0.00113 & 0.135 & 2.17 & 0.153 \\
\hline $7 / 2 / 01$ & 0.00059 & 0.428 & 3.38 & 0.00512 & 0.105 & 0.83 & 0.168 \\
\hline $8 / 6 / 01$ & 0.00034 & 0.39 & 4.99 & 0.00626 & 0.172 & 2.20 & 0.225 \\
\hline $10 / 2 / 01$ & 0.00011 & 0.15 & 1.23 & 0.00088 & 0.2173 & 1.78 & 0.2717 \\
\hline $12 / 4 / 01$ & 0.00020 & 0.46 & 3.08 & 0.00309 & 0.01 & 0.07 & 0.2525 \\
\hline $6 / 26 / 02$ & 0.00064 & 0.478 & 5.21 & 0.00088 & 0.01 & 0.11 & 0.03 \\
\hline Min. & 0.00010 & 0.15 & 1.13 & 0.00076 & 0.01 & 0.05 & 0.03 \\
\hline Max. & 0.00064 & 0.48 & 5.21 & 0.00626 & 0.22 & 2.20 & 0.27 \\
\hline Avg. & 0.00029 & 0.31 & 3.06 & 0.00254 & 0.10 & 1.07 & 0.18 \\
\hline
\end{tabular}


Table E.5. Facility E NO 3 , $\mathrm{NO}_{2}$, and TP.

\begin{tabular}{|c|c|c|c|c|c|c|}
\hline Date & $\begin{array}{c}\text { Nitrate } \\
\text { Nitrogen } \\
\left(\mathrm{NO}_{3}\right), \\
\mathrm{Kg} / \text { day }\end{array}$ & $\begin{array}{c}\text { Influent } \\
\text { Nitrite } \\
\text { Nitrogen } \\
\left(\mathrm{NO}_{2}\right) \text {, } \\
\mathrm{mg} / \mathrm{L}\end{array}$ & $\begin{array}{c}\text { Nitrite } \\
\text { Nitrogen } \\
\left(\mathrm{NO}_{2}\right), \\
\mathrm{mg} / \mathrm{L}\end{array}$ & $\begin{array}{c}\text { Nitrite } \\
\text { Nitrogen } \\
\left(\mathrm{NO}_{2}\right), \\
\mathrm{Kg} \text { /day }\end{array}$ & $\begin{array}{c}\text { Influent } \\
\text { Total } \\
\text { Phosphorus } \\
\text { (TP), } \\
\text { mg/L }\end{array}$ & $\begin{array}{c}\text { Influent } \\
\text { Total } \\
\text { Phosphorus } \\
\text { (TP), } \\
\text { kg/day }\end{array}$ \\
\hline $1 / 17 / 01$ & 0.94 & 0.01 & 0.01 & 0.05 & 0.012 & 0.064 \\
\hline $3 / 1 / 01$ & 2.47 & 0.01 & 0.01 & 0.13 & 0.0005 & 0.006 \\
\hline $5 / 14 / 01$ & 2.46 & 0.01 & 0.01 & 0.16 & 0.0005 & 0.008 \\
\hline $7 / 2 / 01$ & 1.33 & 0.01 & 0.01 & 0.08 & 0.00919 & 0.073 \\
\hline $8 / 6 / 01$ & 2.88 & 0.01 & 0.01 & 0.13 & 0.0064 & 0.082 \\
\hline $10 / 2 / 01$ & 2.22 & 0.01 & 0.01 & 0.08 & 0.026 & 0.213 \\
\hline $12 / 4 / 01$ & 1.69 & 0.01 & 0.01 & 0.07 & 0.065 & 0.436 \\
\hline $6 / 26 / 02$ & 0.33 & 0.01 & 0.01 & 0.11 & 0.018 & 0.196 \\
\hline Min. & 0.33 & 0.01 & 0.01 & 0.05 & 0.00 & 0.01 \\
\hline Max. & 2.88 & 0.01 & 0.01 & 0.16 & 0.07 & 0.44 \\
\hline Avg. & 1.79 & 0.01 & 0.01 & 0.10 & 0.02 & 0.13 \\
\hline
\end{tabular}

Table E.6. Facility E TP, and BOD 5 .

\begin{tabular}{|c|c|c|c|c|c|c|}
\hline Date & $\begin{array}{c}\text { Total } \\
\text { Phosphorus } \\
\text { (TP), } \\
\text { mg/L }\end{array}$ & $\begin{array}{c}\text { Total } \\
\text { Phosphorus } \\
\text { (TP), } \\
\text { Kg/day }\end{array}$ & $\begin{array}{c}\text { Influent } \\
\text { Biochemical } \\
\text { Oxygen } \\
\text { Demand } \\
\left(\mathrm{BOD}_{5}\right), \\
\mathrm{mg} / \mathrm{L}\end{array}$ & $\begin{array}{c}\text { Influent } \\
\text { Biochemical } \\
\text { Oxygen } \\
\text { Demand } \\
\left(\mathrm{BOD}_{5}\right) \text {, } \\
\text { kg/day }\end{array}$ & $\begin{array}{c}\text { Biochemical } \\
\text { Oxygen } \\
\text { Demand } \\
\left(\mathrm{BOD}_{5}\right) \\
\mathrm{mg} / \mathrm{L}\end{array}$ & $\begin{array}{c}\text { Biochemical } \\
\text { Oxygen } \\
\text { Demand } \\
\left(\mathrm{BOD}_{5}\right) \\
\mathrm{Kg} / \text { day }\end{array}$ \\
\hline $1 / 17 / 01$ & 0.098 & 0.53 & 1.43 & 7.68 & 1.43 & 7.68 \\
\hline $3 / 1 / 01$ & 0.0005 & 0.01 & 1.43 & 18.04 & 6.04 & 76.18 \\
\hline $5 / 14 / 01$ & 0.043 & 0.69 & 1.43 & 23.00 & 4.78 & 76.88 \\
\hline $7 / 2 / 01$ & 0.139 & 1.10 & 1.43 & 11.30 & 4.34 & 34.30 \\
\hline $8 / 6 / 01$ & 0.198 & 2.53 & 1.43 & 18.28 & 4.4 & 56.26 \\
\hline $10 / 2 / 01$ & 0.148 & 1.21 & 1.43 & 11.69 & 4.55 & 37.20 \\
\hline $12 / 4 / 01$ & 0.29 & 1.94 & 1.43 & 9.59 & 3.58 & 24.00 \\
\hline $6 / 26 / 02$ & 0.253 & 2.76 & 1.43 & 15.59 & 5.75 & 62.68 \\
\hline Min. & 0.00 & 0.01 & 1.43 & 7.68 & 1.43 & 7.68 \\
\hline Max. & 0.29 & 2.76 & 1.43 & 23.00 & 6.04 & 76.88 \\
\hline Avg. & 0.15 & 1.35 & 1.43 & 14.40 & 4.36 & 46.90 \\
\hline
\end{tabular}


Table E.7. Facility E OLS Pond Flow, pH, Temperature, DO, and Turbidity.

\begin{tabular}{rcccccc}
\multicolumn{1}{c}{ Date } & $\begin{array}{c}\text { Flow, } \\
\text { gal./min. }\end{array}$ & $\begin{array}{c}\text { Flow, } \\
\text { m3/day }\end{array}$ & pH & $\begin{array}{c}\text { Temperature, } \\
{ }^{\circ} \mathrm{C}\end{array}$ & $\begin{array}{c}\text { Dissolved } \\
\text { Oxygen, } \\
\mathrm{mg} / \mathrm{L}\end{array}$ & $\begin{array}{c}\text { Turbidity, } \\
\text { NTU }\end{array}$ \\
\hline $1 / 17 / 01$ & 63 & 343.38 & 7.63 & 11.8 & 9.01 & 5.44 \\
$3 / 1 / 01$ & 562 & 3063.12 & 7.55 & 13.2 & 8.82 & 7.5 \\
$5 / 14 / 01$ & 265 & 1444.36 & 7.27 & 16.5 & 12.48 & 3.63 \\
$7 / 2 / 01$ & 550 & 2997.72 & 7.55 & 15.8 & 8.47 & 6.24 \\
$8 / 6 / 01$ & 550 & 2997.72 & 7.9 & 16.4 & 9.63 & 4.39 \\
$10 / 2 / 01$ & 500 & 2725.20 & 7.21 & 14.5 & 7.92 & 4.43 \\
$12 / 4 / 01$ & 400 & 2180.16 & 7.3 & 14.1 & 8.82 & 4.06 \\
$6 / 26 / 02$ & 450 & 2452.68 & 6.85 & 14.6 & 8.63 & 4.71 \\
\hline Min. & 63.00 & 343.38 & 6.85 & 11.80 & 7.92 & 3.63 \\
Max. & 562.00 & 3063.12 & 7.90 & 16.50 & 12.48 & 7.50 \\
Avg. & 417.50 & 2275.54 & 7.41 & 14.61 & 9.22 & 5.05
\end{tabular}

Table E.8. Facility E Specific Conductance, TSS, TAN, $\mathrm{NH}_{3}$, and $\mathrm{NO}_{3}$.

\begin{tabular}{|c|c|c|c|c|c|c|c|}
\hline Date & $\begin{array}{c}\text { Specific } \\
\text { Conductance, } \\
\mu \mathrm{S} / \mathrm{cm} \\
\end{array}$ & $\begin{array}{c}\text { Total } \\
\text { Suspended } \\
\text { Solids } \\
\text { (TSS), } \\
\text { mg/L } \\
\end{array}$ & $\begin{array}{c}\text { Total } \\
\text { Suspended } \\
\text { Solids } \\
\text { (TSS), } \\
\text { kg/day }\end{array}$ & $\begin{array}{c}\text { Ammonia } \\
\text { Nitrogen } \\
\left(\mathrm{NH}_{3}\right) \\
\mathrm{mg} / \mathrm{L}\end{array}$ & $\begin{array}{c}\text { Ammonia } \\
\text { Nitrogen } \\
\left(\mathrm{NH}_{3}\right), \\
\mathrm{Kg} \text { /day }\end{array}$ & $\begin{array}{c}\text { Unionized } \\
\text { Ammonia } \\
\text { Nitrogen } \\
\left(\mathrm{NH}_{3}\right), \\
\mathrm{mg} / \mathrm{L}\end{array}$ & $\begin{array}{c}\text { Nitrate } \\
\text { Nitrogen } \\
\left(\mathrm{NO}_{3}\right), \\
\mathrm{mg} / \mathrm{L} \\
\end{array}$ \\
\hline $1 / 17 / 01$ & 500 & 5 & 1.72 & 0.421 & 0.14 & 0.00380 & 0.184 \\
\hline $3 / 1 / 01$ & 446.7 & 4 & 12.25 & 0.54 & 1.65 & 0.00452 & 0.186 \\
\hline $5 / 14 / 01$ & 466.8 & 8 & 11.55 & 0.263 & 0.38 & 0.00149 & 0.193 \\
\hline $7 / 2 / 01$ & 237 & 0.5 & 3.00 & 0.378 & 1.13 & 0.00385 & 0.101 \\
\hline $8 / 6 / 01$ & 840 & 7 & 20.98 & 0.19 & 0.57 & 0.00447 & 0.162 \\
\hline $10 / 2 / 01$ & 506 & 7 & 19.08 & 0.13 & 0.35 & 0.00055 & 0.1462 \\
\hline $12 / 4 / 01$ & 555 & 8 & 17.44 & 0.29 & 0.63 & 0.00147 & 0.172 \\
\hline $6 / 26 / 02$ & 507 & 6 & 14.72 & 0.22 & 0.54 & 0.00041 & 0.113 \\
\hline Min. & 237.00 & 0.50 & 1.72 & 0.13 & 0.14 & 0.00041 & 0.10 \\
\hline Max. & 840.00 & 8.00 & 20.98 & 0.54 & 1.65 & 0.00452 & 0.19 \\
\hline Avg. & 507.31 & 5.69 & 12.59 & 0.30 & 0.68 & 0.00257 & 0.16 \\
\hline
\end{tabular}


Table E.9. Facility $\mathrm{E}_{3}, \mathrm{NO}_{2}$, TP, and $\mathrm{BOD}_{5}$.

\begin{tabular}{|c|c|c|c|c|c|c|c|}
\hline Date & $\begin{array}{c}\text { Nitrate } \\
\text { Nitrogen } \\
\left(\mathrm{NO}_{3}\right), \\
\mathrm{Kg} / \text { day }\end{array}$ & $\begin{array}{c}\text { Nitrite } \\
\text { Nitrogen } \\
\left(\mathrm{NO}_{2}\right), \\
\mathrm{mg} / \mathrm{L}\end{array}$ & $\begin{array}{c}\text { Nitrite } \\
\text { Nitrogen } \\
\left(\mathrm{NO}_{2}\right) \text {, } \\
\mathrm{Kg} / \text { day }\end{array}$ & $\begin{array}{c}\text { Total } \\
\text { Phoshorus } \\
\text { (TP), } \\
\text { mg/L }\end{array}$ & $\begin{array}{c}\text { Total } \\
\text { Phoshorus } \\
\text { (TP), } \\
\text { Kg/day }\end{array}$ & $\begin{array}{c}\text { Biochemical } \\
\text { Oxygen } \\
\text { Demand } \\
\left(\mathrm{BOD}_{5}\right) \\
\mathrm{mg} / \mathrm{L}\end{array}$ & $\begin{array}{c}\text { Biochemica } \\
\text { Oxygen } \\
\text { Demand } \\
\left(\mathrm{BOD}_{5}\right) \\
\mathrm{Kg} / \text { day } \\
\end{array}$ \\
\hline $1 / 17 / 01$ & 0.06 & 0.01 & 0.00 & 0.065 & 0.02 & 1.43 & 0.49 \\
\hline $3 / 1 / 01$ & 0.57 & 0.01 & 0.03 & 0.0005 & 0.55 & 3.56 & 10.90 \\
\hline $5 / 14 / 01$ & 0.28 & 0.01 & 0.01 & 0.082 & 0.12 & 1.43 & 2.07 \\
\hline $7 / 2 / 01$ & 0.30 & 0.01 & 0.03 & 0.07 & 0.21 & 1.43 & 4.29 \\
\hline $8 / 6 / 01$ & 0.49 & 0.01 & 0.03 & 0.016 & 0.05 & 1.43 & 4.29 \\
\hline $10 / 2 / 01$ & 0.40 & 0.01 & 0.03 & 0.09 & 0.25 & 1.43 & 3.90 \\
\hline $12 / 4 / 01$ & 0.37 & 0.01 & 0.02 & 0.101 & 0.22 & 1.43 & 3.12 \\
\hline $6 / 26 / 02$ & 0.28 & 0.01 & 0.02 & 0.08 & 0.20 & 1.43 & 3.51 \\
\hline Min. & 0.06 & 0.01 & 0.003 & 0.0005 & 0.02 & 1.43 & 0.49 \\
\hline Max. & 0.57 & 0.01 & 0.03 & 0.10 & 0.55 & 3.56 & 10.90 \\
\hline Avg. & 0.34 & 0.01 & 0.02 & 0.06 & 0.20 & 1.70 & 4.07 \\
\hline
\end{tabular}




\section{APPENDIX F}

Table F.1. Facility F Flow, pH, and Temperature.

\begin{tabular}{rcccccc}
\multicolumn{1}{c}{ Date } & $\begin{array}{c}\text { Flow, } \\
\text { gal./min. }\end{array}$ & $\begin{array}{c}\text { Flow, } \\
\mathrm{m} 3 / \text { day }\end{array}$ & $\begin{array}{c}\text { Influent } \\
\mathrm{pH}\end{array}$ & $\mathrm{pH}$ & $\begin{array}{c}\text { Influent } \\
\text { Temperature, } \\
{ }^{\circ} \mathrm{C}\end{array}$ & $\begin{array}{c}\text { Temperature, } \\
{ }^{\circ} \mathrm{C}\end{array}$ \\
\hline $1 / 17 / 01$ & 1212 & 6605.88 & 7.58 & 7.45 & 12.1 & 12 \\
$3 / 1 / 01$ & 1009 & 5499.45 & 7.13 & 7.09 & 12.4 & 12.2 \\
$5 / 14 / 01$ & 1338 & 7292.64 & 7.21 & 7.17 & 12.9 & 13 \\
$7 / 2 / 01$ & 1042 & 5679.32 & 7.58 & 7.53 & 13.1 & 13.3 \\
$8 / 6 / 01$ & 2123 & 11571.20 & 7.82 & 7.56 & 13.1 & 13.6 \\
$10 / 2 / 01$ & 922 & 5025.27 & 7.43 & 7.38 & 13 & 13.3 \\
$12 / 4 / 01$ & 557 & 3035.87 & 7.52 & 7.3 & 13.1 & 12.6 \\
\hline Min. & 557 & 3035.87 & 7.13 & 7.09 & 12.10 & 12.00 \\
Max. & 2123 & 11571.20 & 7.82 & 7.56 & 13.10 & 13.60 \\
Avg. & 1172 & 6387.09 & 7.47 & 7.35 & 12.81 & 12.86
\end{tabular}

Table F.2. Facility F DO, Turbidity, and Specific Conductance.

\begin{tabular}{rcccccc} 
Date & $\begin{array}{c}\text { Influent } \\
\text { Dissolved } \\
\text { Oxygen, } \\
\text { mg/L }\end{array}$ & $\begin{array}{c}\text { Dissolved } \\
\text { Oxygen, } \\
\text { mg/L }\end{array}$ & $\begin{array}{c}\text { Influent } \\
\text { Turbidity, } \\
\text { NTU }\end{array}$ & $\begin{array}{c}\text { Turbidity, } \\
\text { NTU }\end{array}$ & $\begin{array}{c}\text { Influent } \\
\text { Specific } \\
\text { Conductance, } \\
\mu \mathrm{S} / \mathrm{cm}\end{array}$ & $\begin{array}{c}\text { Specific } \\
\text { Conductance, } \\
\mu \mathrm{S} / \mathrm{cm}\end{array}$ \\
\hline $1 / 17 / 01$ & 11.32 & 8.32 & 3.13 & 6.62 & 500 & 500 \\
$3 / 1 / 01$ & 8.19 & 9.52 & 2.22 & 5.11 & 528 & 526 \\
$5 / 14 / 01$ & 9.81 & 8.65 & 0.62 & 1 & 515 & 522 \\
$7 / 2 / 01$ & 10.2 & 6.98 & 0.63 & 1.51 & 529 & 550 \\
$8 / 6 / 01$ & 10.2 & 7.01 & 2.28 & 1.94 & 539 & 544 \\
$10 / 2 / 01$ & 10.77 & 8.29 & 1.87 & 2.71 & 536 & 543 \\
$12 / 4 / 01$ & 9.02 & 8.97 & 1.82 & 2.91 & 524.1 & 565.9 \\
\hline Min. & 8.19 & 6.98 & 0.62 & 1.00 & 500.00 & 500.00 \\
Max. & 11.32 & 9.52 & 3.13 & 6.62 & 539.00 & 565.90 \\
Avg. & 9.93 & 8.25 & 1.80 & 3.11 & 524.44 & 535.84
\end{tabular}


Table F.3. Facility F TSS and TAN.

\begin{tabular}{ccccccc}
\hline & $\begin{array}{c}\text { Influent } \\
\text { Total } \\
\text { Suspended } \\
\text { Solids } \\
\text { (TSS), }\end{array}$ & $\begin{array}{c}\text { Influent } \\
\text { Total } \\
\text { Suspended } \\
\text { Solids } \\
\text { (TSS), } \\
\text { kg/day }\end{array}$ & $\begin{array}{c}\text { Total } \\
\text { Suspended } \\
\text { Solids } \\
\text { (TSS), } \\
\text { mg/L }\end{array}$ & $\begin{array}{c}\text { Total } \\
\text { Suspended } \\
\text { Solids } \\
\text { (TSS), } \\
\text { kg/day }\end{array}$ & $\begin{array}{c}\text { Influent } \\
\text { Ammonia } \\
\text { Nitrogen } \\
\text { (TAN), } \\
\text { mg/L }\end{array}$ & $\begin{array}{c}\text { Influent } \\
\text { Ammonia } \\
\text { Nitrogen } \\
\text { (TAN), } \\
\text { kg/day }\end{array}$ \\
\hline $1 / 17 / 01$ & 2 & 13.21 & 6 & 39.64 & 0.040 & 0.264 \\
$3 / 1 / 01$ & 3 & 16.50 & 9 & 49.50 & 0.057 & 0.313 \\
$5 / 14 / 01$ & 3 & 21.88 & 3 & 21.88 & 0.042 & 0.306 \\
$7 / 2 / 01$ & 2 & 11.36 & 3 & 17.04 & 0.055 & 0.312 \\
$8 / 6 / 01$ & 1 & 11.57 & 5 & 57.86 & 0.030 & 0.347 \\
$10 / 2 / 01$ & 2.5 & 12.56 & 9 & 45.23 & 0.010 & 0.050 \\
$12 / 4 / 01$ & 3 & 9.11 & 10 & 30.36 & 0.005 & 0.015 \\
\hline Min. & 1.00 & 9.11 & 3.00 & 17.04 & 0.01 & 0.02 \\
Max. & 3.00 & 21.88 & 10.00 & 57.86 & 0.06 & 0.35 \\
Avg. & 2.36 & 13.74 & 6.43 & 37.36 & 0.03 & 0.23
\end{tabular}

Table F.4. Facility $\mathrm{F} \mathrm{NH}_{3}$, TAN, and $\mathrm{NO}_{3}$.

\begin{tabular}{|c|c|c|c|c|c|c|c|}
\hline Date & $\begin{array}{c}\text { Influent } \\
\text { Unionized } \\
\text { Ammonia } \\
\text { Nitrogen } \\
\left(\mathrm{NH}_{3}\right), \\
\mathrm{mg} / \mathrm{L}\end{array}$ & $\begin{array}{c}\text { Ammonia } \\
\text { Nitrogen } \\
\text { (TAN), } \\
\text { mg/L }\end{array}$ & $\begin{array}{c}\text { Ammonia } \\
\text { Nitrogen } \\
\text { (TAN), } \\
\text { Kg/day }\end{array}$ & $\begin{array}{c}\text { Unionized } \\
\text { Ammonia } \\
\text { Nitrogen } \\
\left(\mathrm{NH}_{3}\right), \\
\mathrm{mg} / \mathrm{L}\end{array}$ & $\begin{array}{c}\text { Influent } \\
\text { Nitrate } \\
\text { Nitrogen } \\
\left(\mathrm{NO}_{3}\right), \\
\mathrm{mg} / \mathrm{L}\end{array}$ & $\begin{array}{l}\text { Influent } \\
\text { Nitrate } \\
\text { Nitrogen } \\
\left(\mathrm{NO}_{3}\right) \text {, } \\
\mathrm{kg} \text { day }\end{array}$ & $\begin{array}{c}\text { Nitrate } \\
\text { Nitrogen } \\
\left(\mathrm{NO}_{3}\right), \\
\mathrm{mg} / \mathrm{L}\end{array}$ \\
\hline $1 / 17 / 01$ & 0.00033 & 0.54 & 3.57 & 0.00328 & 0.198 & 1.308 & 0.212 \\
\hline $3 / 1 / 01$ & 0.00017 & 0.65 & 3.57 & 0.00176 & 0.235 & 1.292 & 0.289 \\
\hline $5 / 14 / 01$ & 0.00016 & 0.135 & 0.98 & 0.00047 & 0.118 & 0.861 & 0.145 \\
\hline $7 / 2 / 01$ & 0.00049 & 0.352 & 2.00 & 0.00284 & 0.096 & 0.545 & 0.113 \\
\hline $8 / 6 / 01$ & 0.00046 & 0.25 & 2.89 & 0.00221 & 0.208 & 2.407 & 0.214 \\
\hline $10 / 2 / 01$ & 0.00006 & 0.13 & 0.65 & 0.00074 & 0.1479 & 0.743 & 0.1339 \\
\hline $12 / 4 / 01$ & 0.00004 & 0.46 & 1.40 & 0.00208 & 0.0775 & 0.235 & 0.1755 \\
\hline Min. & 0.00004 & 0.13 & 0.65 & 0.00047 & 0.08 & 0.24 & 0.11 \\
\hline Max. & 0.00049 & 0.65 & 3.57 & 0.00328 & 0.24 & 2.41 & 0.29 \\
\hline Avg. & 0.00024 & 0.36 & 2.15 & 0.00191 & 0.15 & 1.06 & 0.18 \\
\hline
\end{tabular}


Table F.5. Facility $\mathrm{F} \mathrm{NO}_{3}, \mathrm{NO}_{2}$, and TP.

\begin{tabular}{rcccccc} 
& $\begin{array}{c}\text { Nitrate } \\
\text { Nitrogen } \\
\left(\mathrm{NO}_{3}\right),\end{array}$ & $\begin{array}{c}\text { Influent } \\
\text { Nitrite } \\
\text { Nitrogen } \\
\left(\mathrm{NO}_{2}\right),\end{array}$ & $\begin{array}{c}\text { Nitrite } \\
\text { Nitrogen } \\
\left(\mathrm{NO}_{2}\right),\end{array}$ & $\begin{array}{c}\text { Nitrite } \\
\mathrm{Nitrogen} \\
\left(\mathrm{NO}_{2}\right),\end{array}$ & $\begin{array}{c}\text { Influent } \\
\text { Total } \\
\text { Phosphorus } \\
(\mathrm{TP}),\end{array}$ & $\begin{array}{c}\text { Influent } \\
\text { Total } \\
\text { Phosphorus } \\
(\mathrm{TP}),\end{array}$ \\
$\begin{array}{r}\mathrm{Kg} / \text { day } \\
\text { Date }\end{array}$ & 1.40 & 0.01 & 0.01 & 0.07 & 0.0005 & 0.0033 \\
$3 / 17 / 01$ & 1.59 & 0.01 & 0.01 & 0.05 & 0.0005 & 0.0027 \\
$5 / 14 / 01$ & 1.06 & 0.01 & 0.01 & 0.07 & 0.0005 & 0.0036 \\
$7 / 2 / 01$ & 0.64 & 0.01 & 0.01 & 0.06 & 0.0097 & 0.0551 \\
$8 / 6 / 01$ & 2.48 & 0.01 & 0.01 & 0.12 & 0.01144 & 0.1324 \\
$10 / 2 / 01$ & 0.67 & 0.01 & 0.01 & 0.05 & 0.044 & 0.2211 \\
$12 / 4 / 01$ & 0.53 & 0.01 & 0.01 & 0.03 & 0.065 & 0.1973 \\
\hline Min. & 0.53 & 0.01 & 0.01 & 0.03 & 0.00 & 0.00 \\
Max. & 2.48 & 0.01 & 0.01 & 0.12 & 0.07 & 0.22 \\
Avg. & 1.20 & 0.01 & 0.01 & 0.06 & 0.02 & 0.09
\end{tabular}

Table F.6. Facility F TP, and BOD 5 .

\begin{tabular}{|c|c|c|c|c|c|c|}
\hline Date & $\begin{array}{c}\text { Total } \\
\text { Phosphorus } \\
\text { (TP), } \\
\text { mg/L }\end{array}$ & $\begin{array}{c}\text { Total } \\
\text { Phosphorus } \\
\text { (TP), } \\
\text { Kg/day }\end{array}$ & $\begin{array}{c}\text { Influent } \\
\text { Biochemical } \\
\text { Oxygen } \\
\text { Demand } \\
\left(\mathrm{BOD}_{5}\right) \text {, } \\
\text { mg/L }\end{array}$ & $\begin{array}{c}\text { Influent } \\
\text { Biochemical } \\
\text { Oxygen } \\
\text { Demand } \\
\left(\mathrm{BOD}_{5}\right), \\
\text { kg/day }\end{array}$ & $\begin{array}{c}\text { Biochemical } \\
\text { Oxygen } \\
\text { Demand } \\
\left(\mathrm{BOD}_{5}\right) \\
\mathrm{mg} / \mathrm{L}\end{array}$ & $\begin{array}{c}\text { Biochemical } \\
\text { Oxygen } \\
\text { Demand } \\
\left(\mathrm{BOD}_{5}\right) \\
\mathrm{Kg} / \text { day }\end{array}$ \\
\hline $1 / 17 / 01$ & 0.084 & 0.55 & 1.43 & 9.45 & 1.43 & 9.45 \\
\hline $3 / 1 / 01$ & 0.0005 & 0.003 & 1.43 & 7.86 & 1.43 & 7.86 \\
\hline $5 / 14 / 01$ & 0.06 & 0.44 & 1.43 & 10.43 & 1.43 & 10.43 \\
\hline $7 / 2 / 01$ & 0.096 & 0.55 & 1.43 & 8.12 & 5.6 & 31.80 \\
\hline $8 / 6 / 01$ & 0.131 & 1.52 & 1.43 & 16.55 & 4 & 46.28 \\
\hline $10 / 2 / 01$ & 0.145 & 0.73 & 1.43 & 7.19 & 3.93 & 19.75 \\
\hline $12 / 4 / 01$ & 0.186 & 0.56 & 1.43 & 4.34 & 1.43 & 4.34 \\
\hline Min. & 0.00 & 0.00 & 1.43 & 4.34 & 1.43 & 4.34 \\
\hline Max. & 0.19 & 1.52 & 1.43 & 16.55 & 5.60 & 46.28 \\
\hline Avg. & 0.10 & 0.62 & 1.43 & 9.13 & 2.75 & 18.56 \\
\hline
\end{tabular}

